
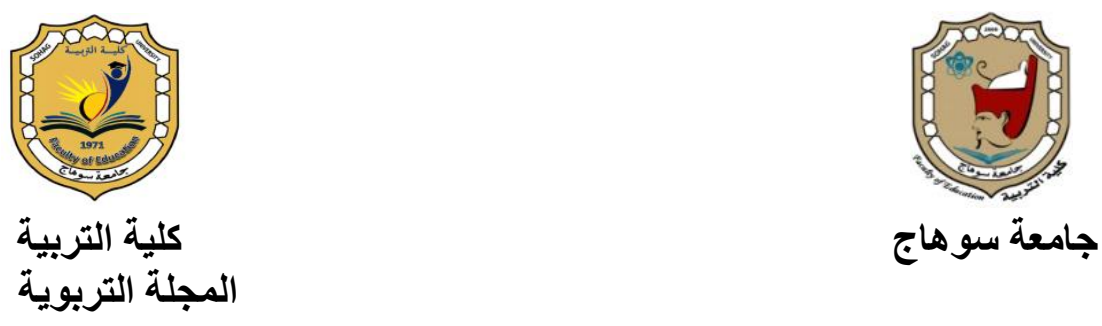

واقع الدهج التعليمي وصعوباته بين التلاميذ المعاقين عقليًا في ظل تشريعات الدهم الشامل بمدارس التعليم العام (دراسة تصليلية)

$$
\begin{aligned}
& \text { إعداد } \\
& \text { د/ حامد أبو عقرب إبراهيه عبد العال } \\
& \text { دكتوراه - قسم أصول التربية } \\
& \text { كلية التربية - جامعة سوهاج }
\end{aligned}
$$

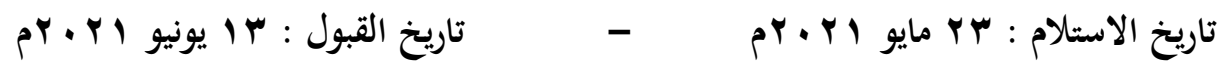

DOI: 10.12816/EDUSOHAG.2021. 


\section{ملغصن اللدراسة}

سـت الاراسـة الحاليـة إلى التعرف على واقع دمـج المعاقين عقلياً بمدارس التعليم العام والتعرف على أهم الصعويات والمعوقات التي تحول دون تحقيق الهـف مـن دمجهم مـع العاديين ووضع بعض المقترحات تقوم على البناء على الإيجابيات وتلافي الصعويات والمعوقات.

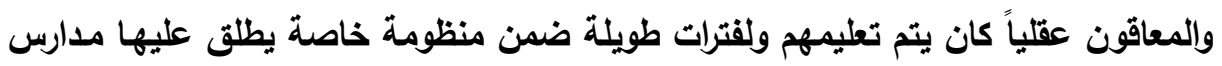

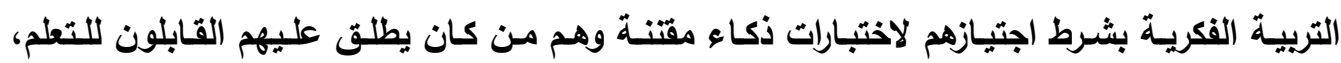

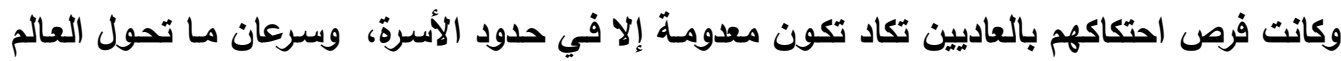

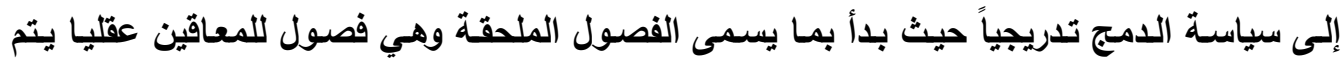

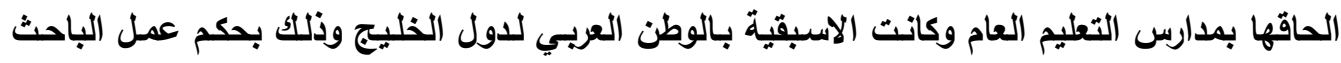

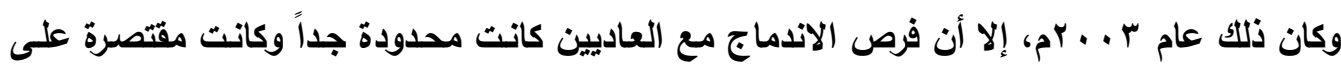

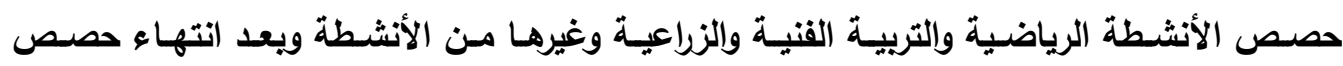

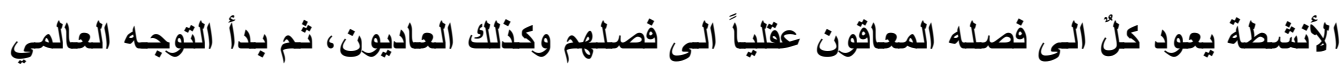

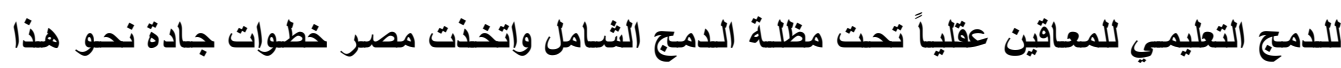
الاتجاه وسن تثريعات عديدة تسهم في دمج ذوي الاحتياجات الخاصة بمن فيهم المعاقين عقلياً إلا

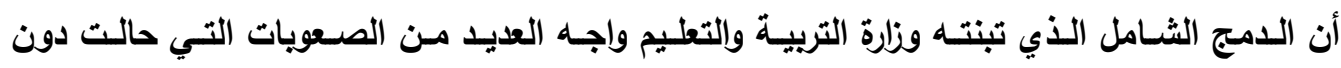
الاستفادة المثلى والكبيرة من فكرة الدمج وهذه هي مشكلة الدراسة الحالية التي بصددها لهادئ الباحث. حيث رصد الباحث واقع دمج المعاقين عقلياً بمدارس التعليم العام بعد سلسلة من فن القرارات

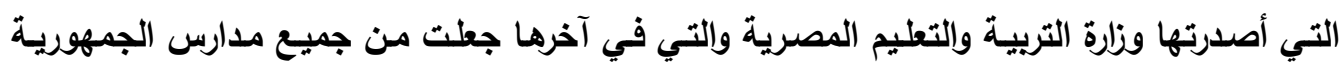

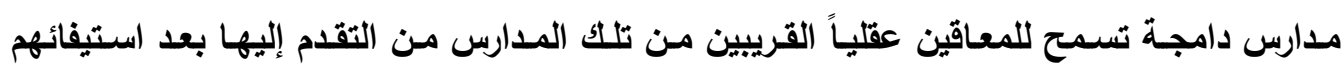

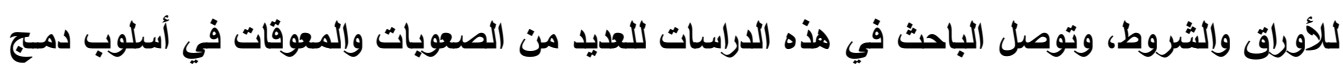

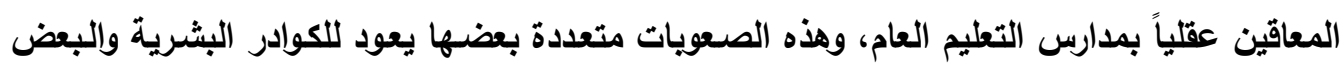

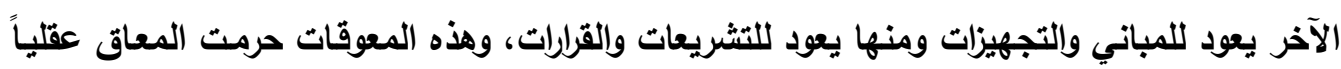

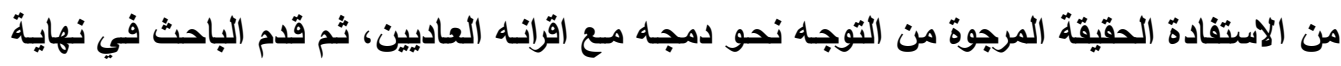

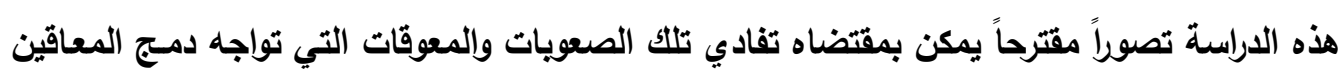
عقلياً مع العاديين.

الكلمات المفتاحية: الامجج التعليمي ـصعوياته ـ التلاميذ المعاقين عقلياً ـ تثريعات ــ الدمج الثَامل -مدارّس التعليم العام 
"The Reality of Educational Integration and its Difficulties Among Mentally Handicapped Students Through the Comprehensive Integration Legislation in Public Education Schools" (Analytical

\section{Study summary}

\section{Study)}

The current study sought to identify the reality of integrating the mentally handicapped in general education schools and to identify the most important difficulties and obstacles that prevent the achievement of the goal of integrating them with the ordinary and to put some proposals based on building on the positives and avoiding difficulties and obstacles.

And the mentally handicapped were taught for long periods within a special system called schools of intellectual education, provided they passed codified intelligence tests, and they were the ones who were called the educators, and the chances of them coming into contact with the ordinary were almost non-existent except within the family, and soon the world turned to a policy of gradual integration as it began The so-called attached classes, which are classes for the mentally handicapped, are attached to general education schools, and the precedence was in the Arab world for the Gulf states, by virtue of the researcher's work, and that was in 2003. However, the opportunities for integrating with the ordinary people were very limited and were limited to sports activities, artistic and agricultural education and other activities, and after the end of the activities classes, everyone returns to his class, the mentally disabled, to their class as well as the ordinary. Then the global trend of educational integration of the mentally disabled began under the umbrella of comprehensive integration and Egypt took Serious steps towards this direction and the enactment of many legislations that contribute to the integration of people with special needs, including the mentally handicapped. However, the comprehensive integration adopted by the Ministry of Education faced many difficulties that prevented the optimum and great benefit from the idea of inclusion, and this is the problem of the current study that the researcher is dealing with.

Where the researcher monitored the reality of integrating the mentally handicapped into public education schools after a series of decisions issued by the Egyptian Ministry of Education, which at the end of which made all the schools of the Republic inclusive schools that allow the mentally handicapped close to those schools to apply to them after fulfilling the papers and conditions, and the researcher found in these studies There are many difficulties and obstacles in the method of integrating the mentally handicapped into public education schools, and these difficulties are multiple, some of which are due to human cadres and others are due to buildings and equipment, including to legislation and decisions. At the end of this study, a proposed 
scenario can be avoided according to which those difficulties and obstacles that face the integration of the mentally disabled with the ordinary ones can be avoided.

Key Words: Educational Integration - its Difficulties - Mentally Handicapped Students - the Comprehensive- Integration Legislation - Public Education Schools 


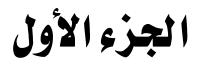 \\ الإطار التمهيدي للدراسة}

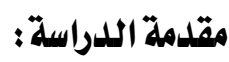

يقاس تحضر الأمم والدول وكذلك تقدمها بمدى اهتمامها برعايـة وتربية وتعليم ذوي

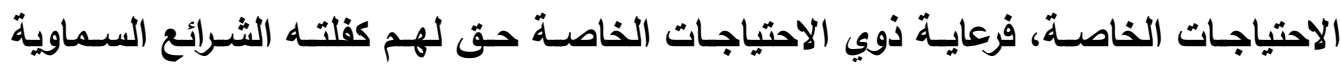
والقوانين الوضعية وذلك لاستغلال طاقاتهم ويقايا قدراتهم وتجنباً لتعطيل تلك القدرات والطاقات لهات وتحوليهم مـن مـواطنين يعانون مـن تأثير إعاقاتهم إلى مـواطنين منتجين يشـاركون أقرانهم

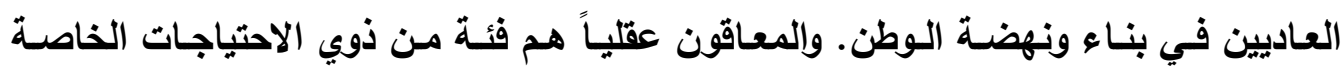
يحتاجون للرعاية وللتدريب وللتعليم مثلهم مثل باقي الإعاقات وكذلك العاديين.

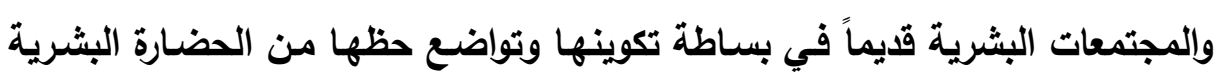

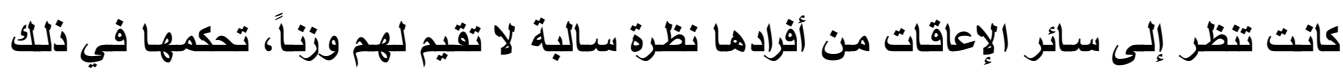

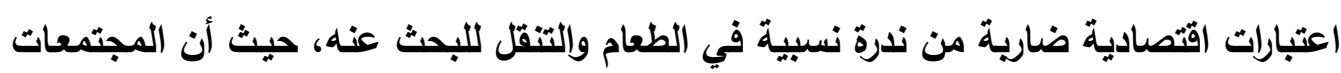

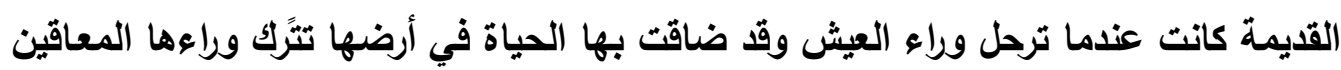

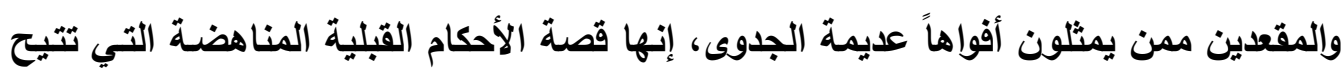
للبشرية أن تتخلص انفعالياً من بعض جماعات الأقلية المنتمين إليها، ومن ثم يكون بوسعها الإها

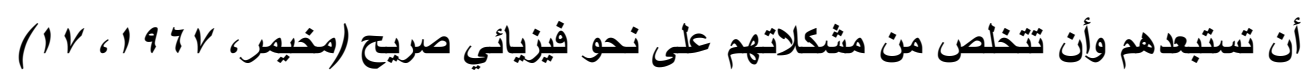

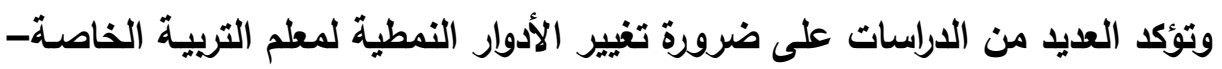

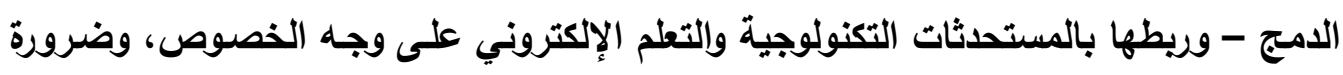
الاهتمام بإعداد وتدريب المعلم يعد ركيزة اساسية لتفعيل أدواره في التدريس والعمل مـع فئسة المعاقين المنوط بتعليمها وتدريبها، وضرورة عمل برامج إعداد وتدريب المعلم وخاصـة معلم

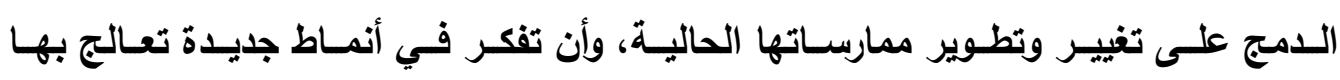
المشكلات؛ لمساعدة التلاميذ ذوى الاحتياجات الخاصة لتحقيق مستقبل تعليمي أفضل لهوئلاء التلاميذ، ويعد ظهور قانون التعليم للجميع الذى ألزم بضرورة أن يتلقى جميع التلاميذ ذوى دئيل الاحتياجات الخاصـة تعليمهم في معظم المدارس أدى بدوره إلى تغيير طريقة إعداد وتأهيل

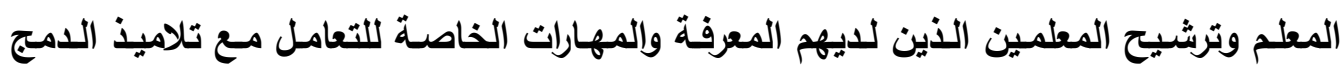




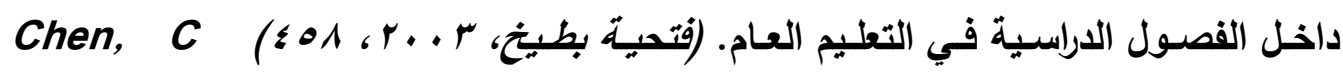
.2007,65-76) \& William. \& Michael, 1992, 24)

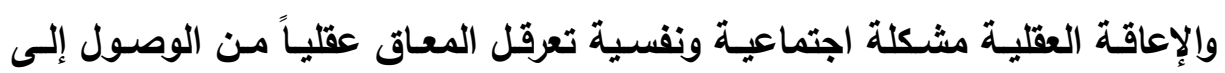

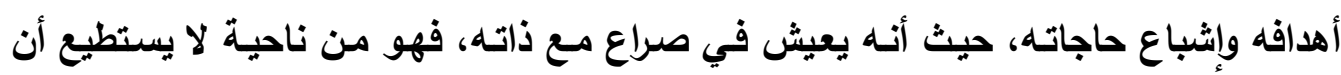
يندمج مع العاديين، ومن ناحية أخرى لا يرضسى عن العيش منعزلاً مـع عالمـه المحدود طالما

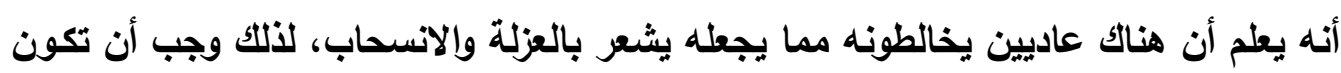

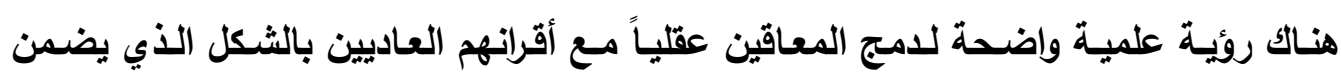
تعليمهم وتربيتهم بالشكل السليم وفق روئية وفلسفة التربية الخاصة.

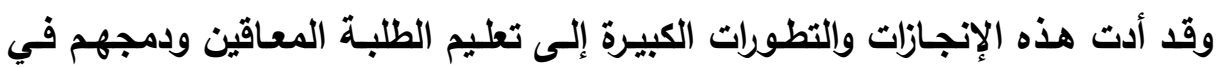
التعليم العام، ففي القرن الحادي والعثرين، تغيرت النظرة السلبية تجاه المعاقين إلى نظرة تفاؤلية تقوم على الامج التعليمي لا العزل وإلفصل في مدارس خاصة، حيث أكلدت العبدئ العديد من

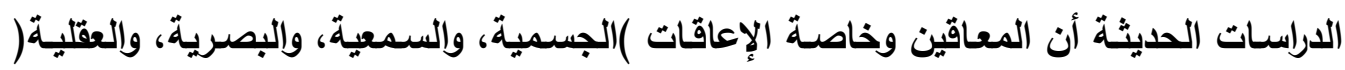

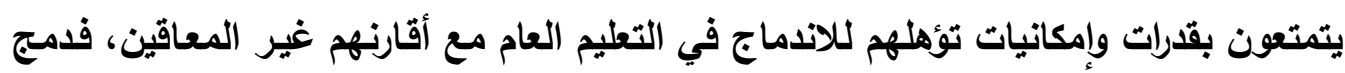

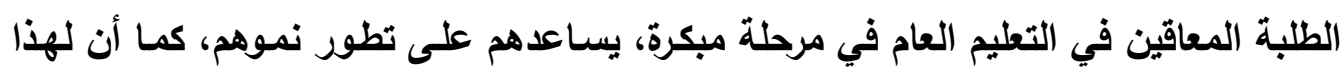

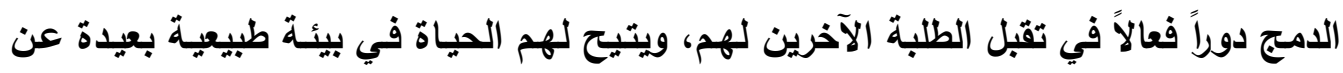

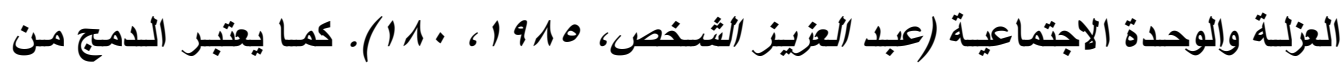

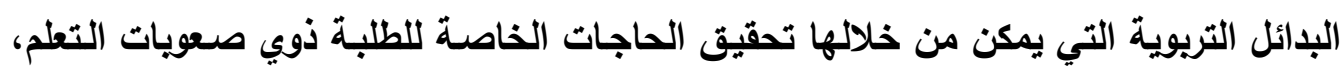

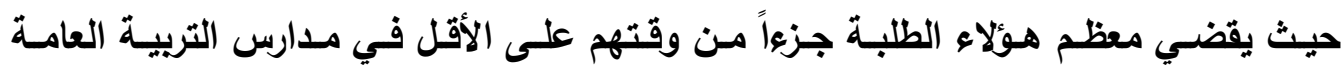

(Heward,2003, 66)

وقد توصلت (منسى أبو المواهب، 1 ـ ب)، في دراستها التي هدفت إلى التعرف على

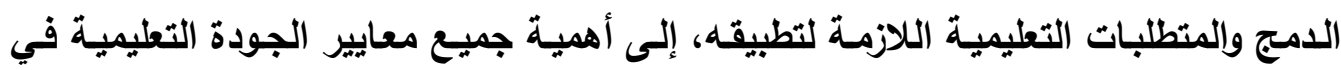
برامج الدمج لذوي الإعاقة من وجهة نظر عينة البحث. وهذا يؤكد على ضرورة أن تكون هذه

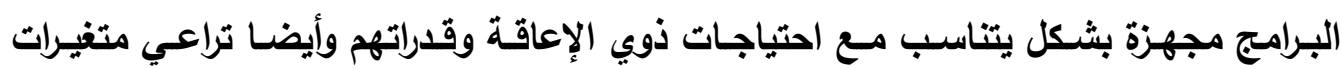

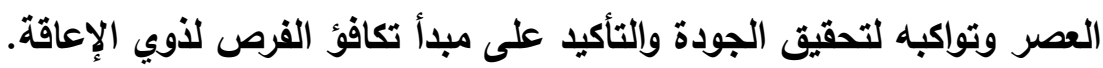

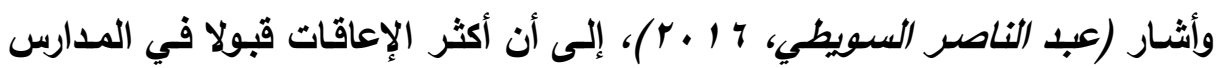

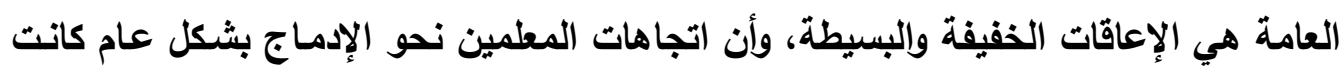


ايجابية في دراسته التي هدفت إلى معرفة اتجاهات وآراء مدرسي وإداري المرحلة الابتدائية

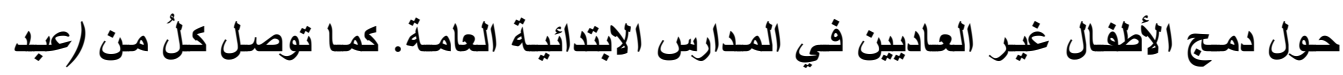

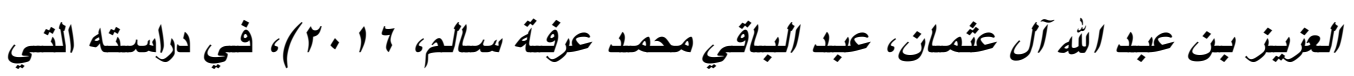

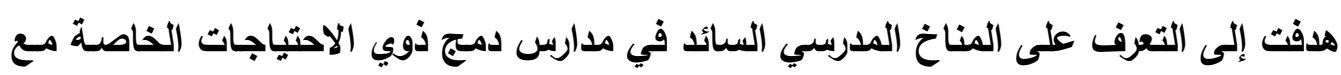
العاديين إلى أن المنـاخ المدرسي السـائد في مدارس الدمج ايجابيا مـن ناحيـة نمسط الإدارة

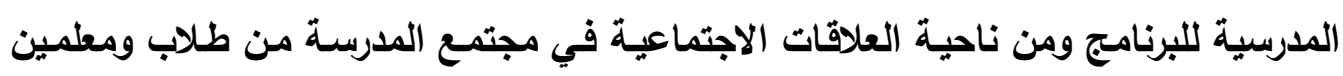
وأولياء أمور ومن ناحية البيئة المدرسية.

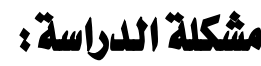

رغم أهمية دمـج المعاقين عقلياً مـع أقرانهم العـاديين بمدارس التعليم العام والفتـي بمختلف مراحلـه، إلا أن هذا النظـام يواجـه بعض الصعويات في التطبيق، ولا يـزال الأطفـال

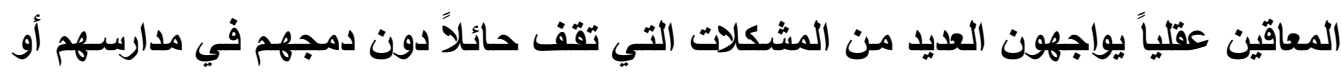
في مجتمعهم، وتجعهم يشعرون بالإحباط وعدم تحقيق الفائدة المثلى من دمجهم مـع أقرانهم العاديين.

فقد أظهرت دراسـة (Platt,2002) وجود مشكلات لدى الطفل المعاق ذهنيا تتمثل

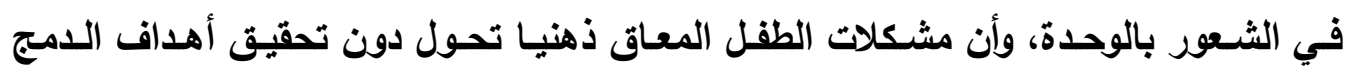
الاجتماعي، وتوظيف قراته وإمكاناته المتاحة. وأظهرت دراسة (على ويلوي، ؛ . . r) من خلال التعرف على واقع تجربـة الدمج في

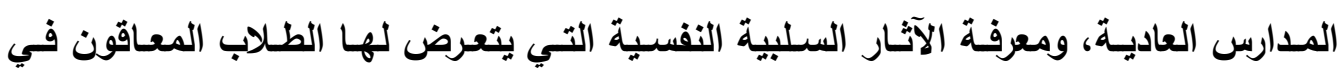

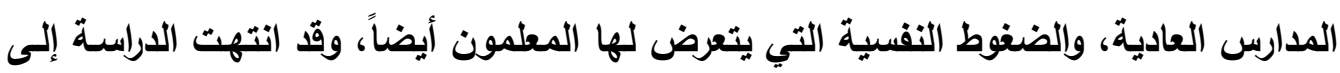
تأكيدها على أهية سياسة الامج، وأوصت بضرورة تذليل العقبات التي تحول دون الاستفادة

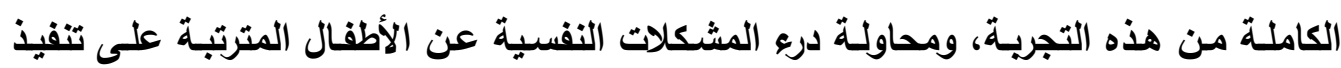

سياسة الامجج.

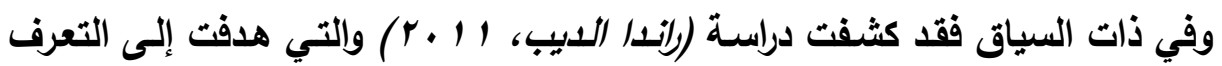

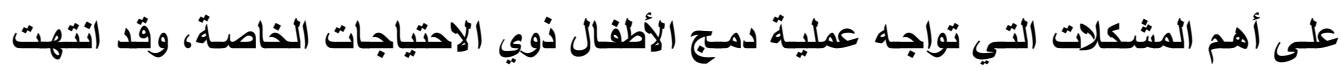

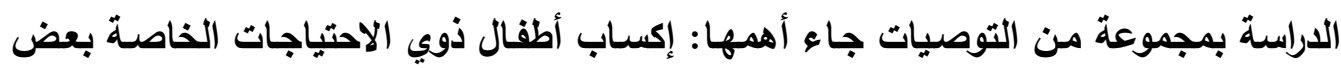


المهارات الاجتماعية الأساسية، كذلك أهمية تعديل البيئة الصفية قبل إجراء الامج لكي تصبح مناسبة لأطفال ذوي الاحتياجات الخاصة، مما يزيد من المهارات الاجتماعية لايهم.

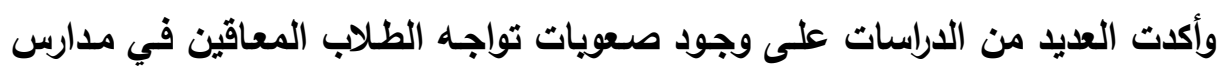

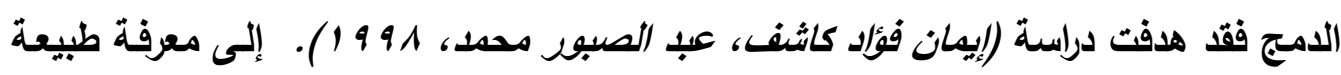

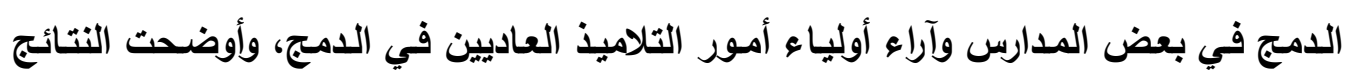
وجود بعض المدارس لا يتم فيها الدمج، والحجرة الدراسية فيها مستويان دراسيان كما اتفق

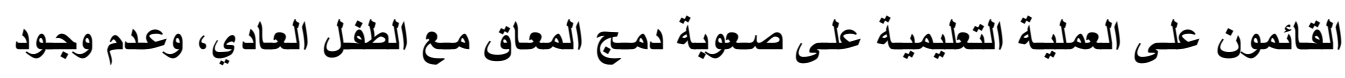
خطة واضحة لأهداف الدمج يؤدي إلى فشلها، ورفض آباء الأطفال العاديين وآباء الأطفال

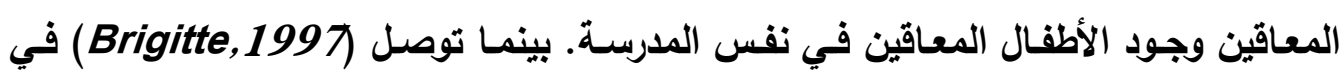

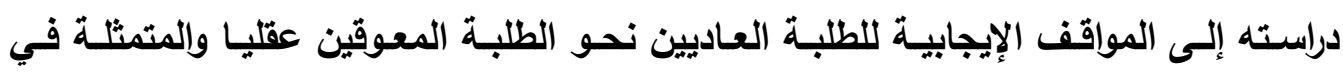

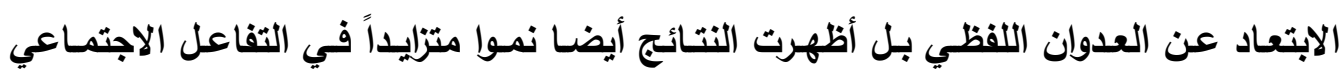

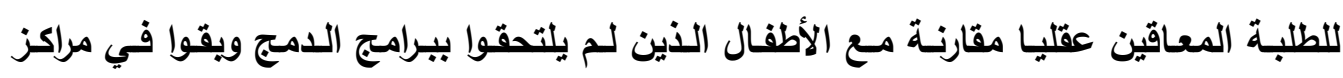
التربية الخاصة النهارية. لذلك تحددت مشكلة الدراسة الحالبة في النقاط التالية: • يشعر المعاقون عقلياً بعدم الاندماج الحقيقي مع أقرانهم الاسوياء.

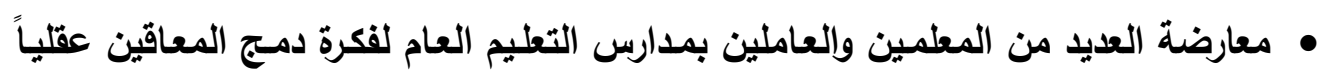
مع أقرانهم العاديين.

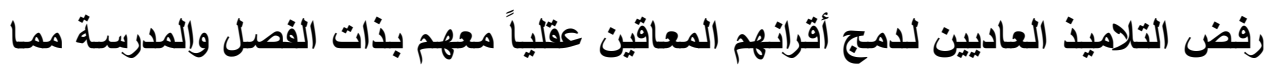
يسبب تدهوراً في فرص تهيئة المنـاخ الـلازم للتفاعل والتواصل بين التلاميذ المعاقين

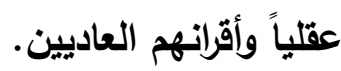
قـأة توافر الخدمات المسـاتدة للمعاقين عقلياً بمدارس التعليم العام والتي تسـهل عملية دمجهم مع أقراتهم العاديين؛ من غرفة للمصادر، وغرفة للتخاطب.

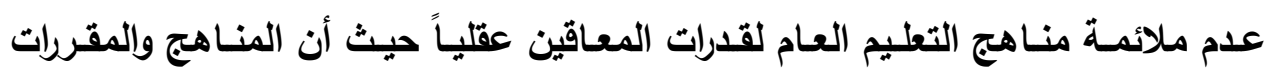
الدراسية المطبقة على العاديين هي نفسه مطبقة على المعاقين عقلياً المدمجين. عدم ملائمة وسائل التقويم والامتحان للمستوى الاراسي للمعاقين عقلياً رغم وجود بعض هلئ المحاولات لتبسيطها وجعلها موضوعية فقط. 
• المعلمون المباشرون بمدارس التعليم العام والذين لهم تلخل مباشر مع الأطفال المعاقين

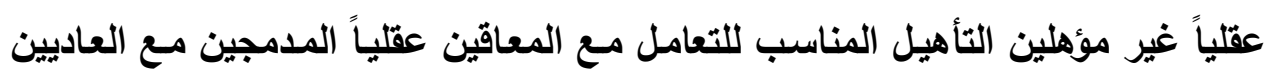

$$
\text { بمدارس التعليم العام. }
$$

ومما سبق فهناك حاجة ماسة إلى التعرف على واقع دمج التلاميذ المعاقين عقلياً بمدارس

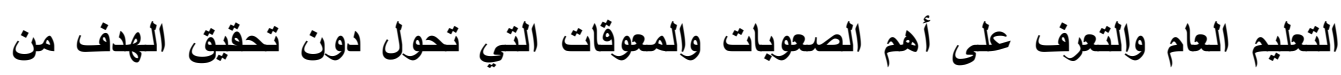

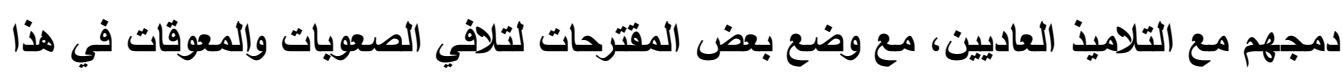

المجال

\section{أسئالة الدباسلدال:}

سعت الاراسة الحالية للإجابة على التساؤل الرئيس الآتي:

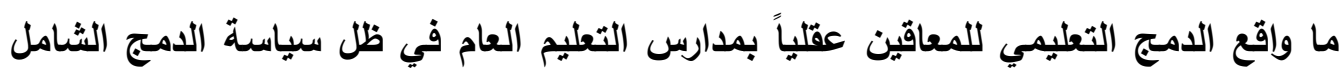

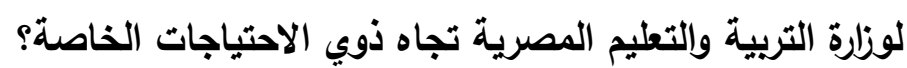
وللإجابة عن التساؤل الرئيس للاراسة، تجيب الدراسة عن الأسئلة الفرعية الآتية: س ا: ما المقصود بالامجج التعليمي بمدارس التعليم العام؟.

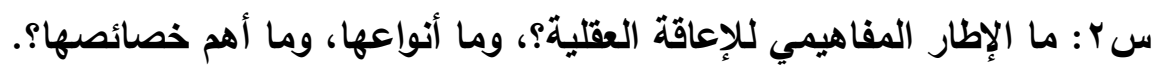
سب: ما واقع نسب التلاميذ المعاقين عقليا بمدارس التعليم العام بعد قرار دمجهم طبقا

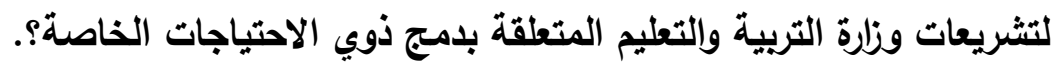
سء: ما التوصيات المقترحة لدمج التلاميذ المعاقين عقليا بمدارس التعليم العام بطريقة لإهية تضمن تربيتهم وتعليمهم بشكل جيد؟.

\section{أهداق الداساسة}

تحددت أهداف الدراسة الحالية في النقاط التالية: • تسليط الضوء على المعاقين عقليا وواقع تربيتهم وتعليمهم في مصر. • التعرف على مدى فعالية نظام الدمج المتبع حالياً من قبل وزارة التربية والتعليم المصرية. • تبني روئة مستقبلية لامج المعاقين عقلياً في مصر بصورة تراعي ظروف إعاقتهم. • يسعى البحث إلى تقديم بعض المقترحات لامج المعاقين عقليا بمدارس التعليم العام بشكل يضمن تربيتهم وتعليمهم بشكل جيد. 
• التعرف على أهم المعوقات التي تواجه المعاقين عقلياً بعد دمجهم مع العاديين.

أفمية الدراسية

نبعت أهمية الدراسـة الحاليـة من أنها تقوم برصد واقـع دمـج المعاقين عقلياً بمدارس التعليم العام بمصر والتعرف على أهم العقبات التي تواجه عملية دمجهم مع العاديين. وظهرت أهمية الاراسة والحاجة إليها من عدة جوانب هي: •محاولة دفع المسؤولين إلى مزيد من الاهتمام نحو تربية وتعليم فئة المعاقين عقليا. •رصـد وتتـاول أهـم القـرارات الإداريـة المتعلقـة بـدمج المعـاقين عقليـا مـن قبـل وزارة التربيـة والتعليم.

•قد تسهم هذه الاراسة في إثراء التراث الأكاديمي المتعلق بذوي الاحتياجات الخاصة. •توفير قدر من البيانات والمعلومات عن طبيعة دمج المعاقين عقلياً مع العاديين.

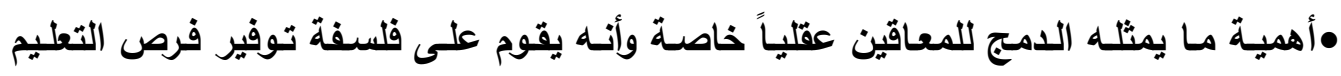
للجميع. •أن إعاقة الطفل العقلية يترتب عليها العديد مـن المشكلات بشكل يتطلب تقديم خدمات

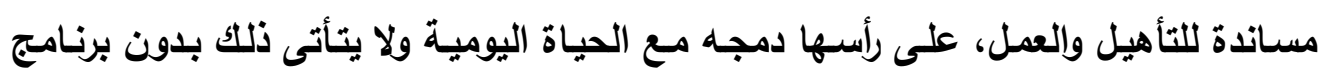
دمج مع العاديين.

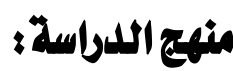

أعتمد الباحث في الدراسـة الحاليـة على المنهج التحليلي باعتبـاره أسـلوب لإيضـاح

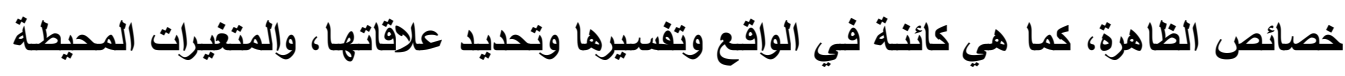

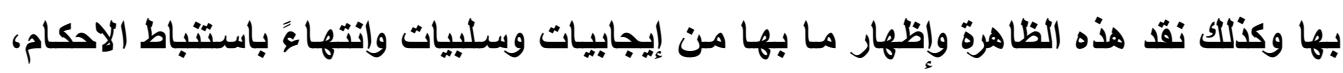
وقد استخدام الباحث المنهج التحليلي خلال الدراسة الحالية فيما يأتي: -

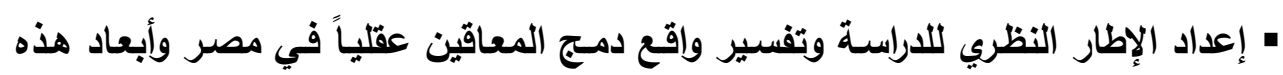
الدراسة وفصولها المتعددة. ـ قـام الباحث بنقـد القـوانين والقـرارات الإداريـة لـوزارة التربيـة والتعليم والمتعلقـة بـدمج المعاقين عقلياً بمدارس التعليم العام. • تحليل مشكلات دمج المعاقين عقلياً والتوصل إلى حلول لتلك المشكلات. 
• استتباط ووضـع مجموعـة الاقتراحـات لمشكلات دمـج المعاقين عقليـاً بمدارس التعليم العام في مصر من خلال بعض التصورات المقترحة.

\section{حلدود الدلداسة2:}

اقتصرت الدراسة على التعرف على واقع الامج التعليمي للمعاقين عقلياً بمدارس التعليم العام في ظل سياسة الامج الثامل مصرية تجاه ذوي الاحتياجات الخاصة.

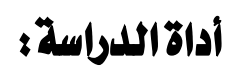

اعتمد الباحث في هذه الدراسـة على المنهج التحليلي ومن ثم استخدم الباحث أهم

وسائل المنهج التحليلي من تفسير ونقد وإستباط، فقام الباحث بتفسير ظاهرة دمـج المعاقين

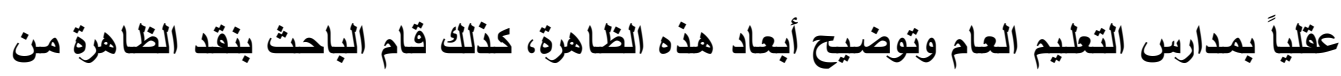

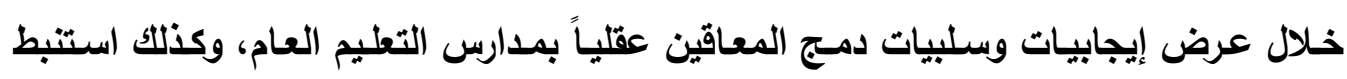

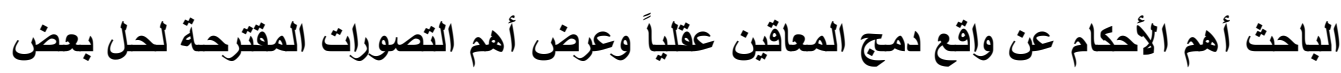

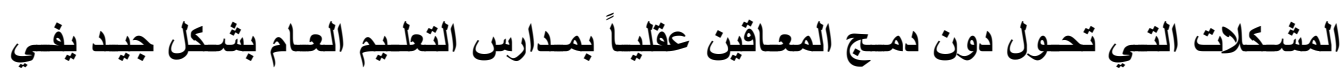
باحتياجاتهم.

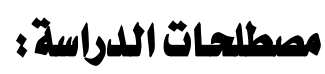

\section{Full Inclusion مفهوم اللدمج الثشامل}

يعني الامج الثامل؛ وضع جميع الطلبة ذوي الحاجات الخاصـة في المدارس العامـة المجاورة لأماكن سكنهم أو إقامتهم، ويتحمل معلم التربية العامـة المسؤولية الأولية في تعليم هذه الفئة من الطلاب. Hallahan and Kauffman, 2006, 203) وعرف الباحث الدمج الثـامل إجرائياً على أنسه "وضـع الطلاب المعاقين عقليـاً ممن من تنطبق عليهم الشروط التي قتنتها وزارة التربية والتعليم مع الطلاب العاديين بمدارس التعليم العام والمدارس الفنية في ذات الفصل مـع تقديم بعض الخدمات المسـاندة للطلاب المعاقين عقلياً" 


\section{اللامج التمليمي Inclusive Education}

يعرف الدمجج بأنـه: عملية دمـج الأطفـال ذوي الاحتياجـات الخاصـة في المـارس أو

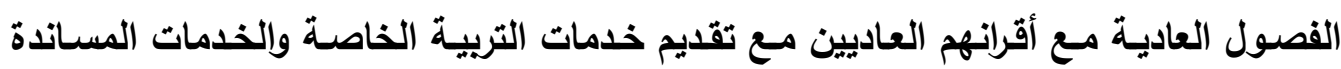

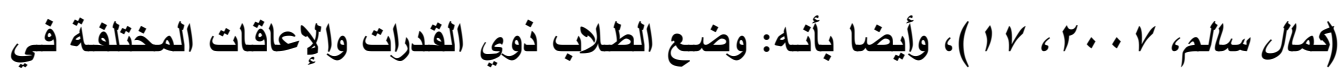

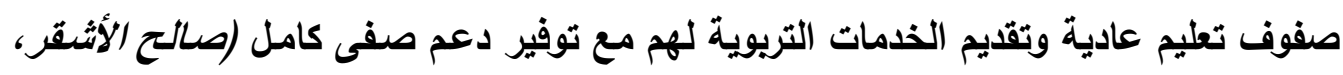

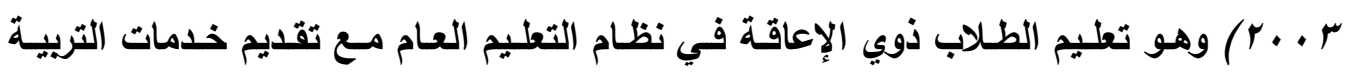
الخاصة بهم في الفصل ذاته. (Ripley, K.2001,17) واللـدمج التعليمسي هـو تعليم جميـع الطـلاب سـواء كـانوا مـن ذوي الإعاقـة أو غيـر

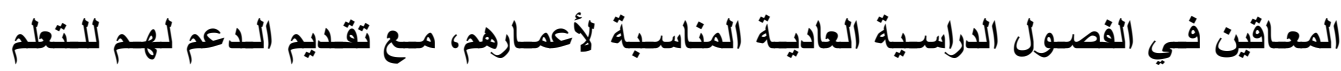

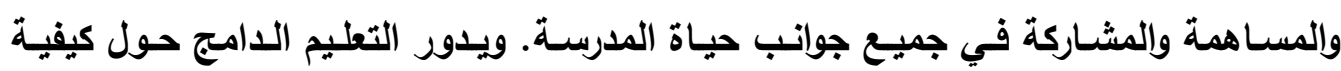

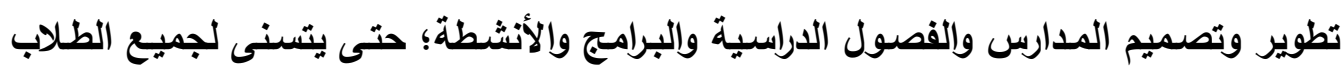
التعلم وإلمشاركة معاً.

وعرف الباحث الدمج التعليمي إجرائياً "بأنـهـ نظـام أو أسلوب يســح بوجـود الطفل

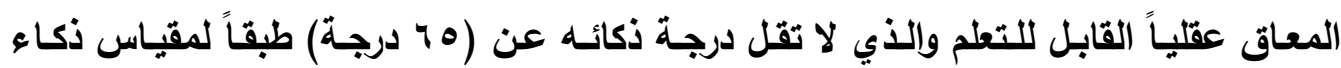

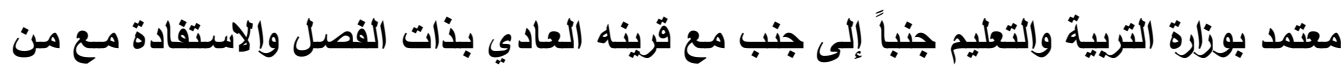

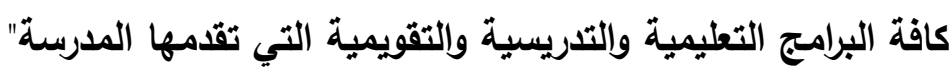

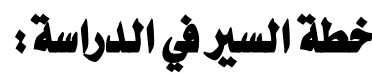

للإجابة عن أسئلة الاراسة الحالية وتحقيق أهدافها، سارت الدراسة وفقاً للإجراءات الآتية: أولاً: تناول الباحث مشكلة الدراسة وأسئلتها وأهميتها وأهدافها ومنهجيتها ومصطلحاتها لهارتها وحدودها وذلك من خلال الجزء الأول من الدراسة بعنوان "الإطار التمهيدي".

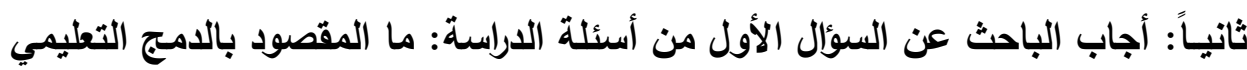
بمدارس التعليم العام؟. من خلال تخصيص البند الأول من الاراسة بعنوان " الامج التعليمي وأهم أنواعه ومميزاته وسلبياته". 
ثالثاً: أجساب الباحث عن السؤال الثاني من أسـئلة الدراسـة: مـا الإطـار المفـاهيمي للإعاقة

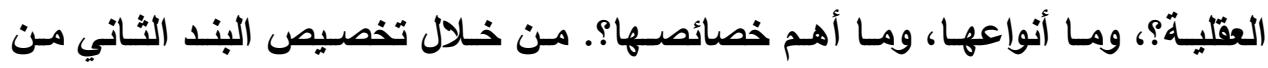
الدراسة بعنوان: " الإعاقة العقلية؛ الأنواع والخصائص ".

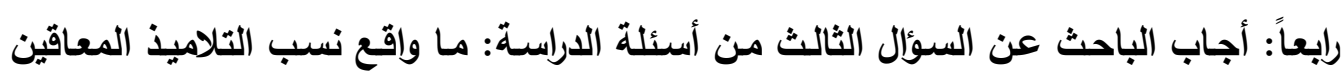

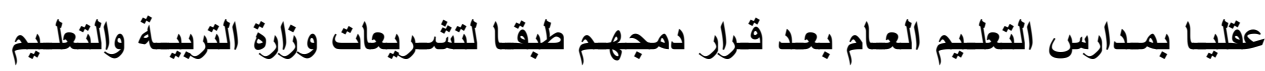

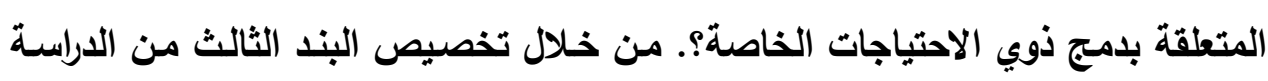

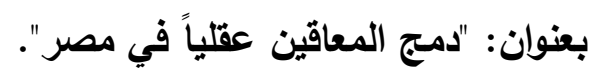

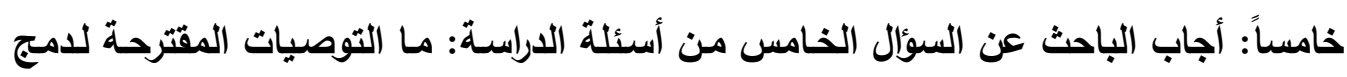
التلاميذ المعاقين عقليا بمدارس التعليم العام بطريقة تضمن تربيتهم وتعليمهم بشكل

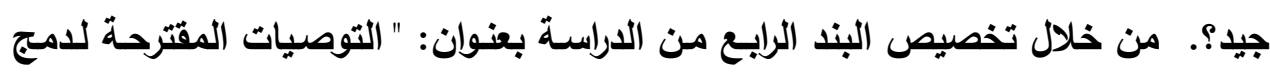
المعاقين عقلياً في مصر" مئل

\section{الجزئ الأثاذب}

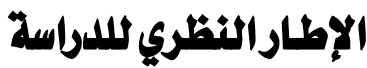

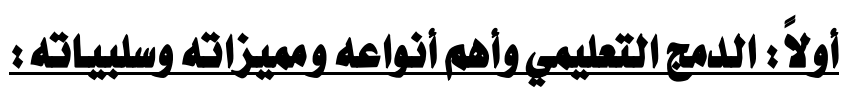

(1) مفهوم اللدمج التمليمي)

يشير مفهوم دمـج الطلبة المعاقين إلى وضعهم وتعليمهم في صفوف التربية العامـة،

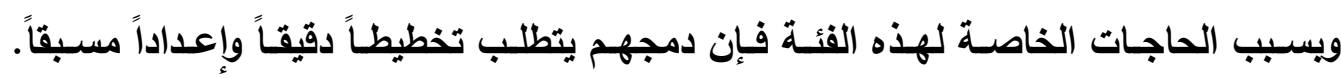
(Lemer, 2003, 91). كما يعرف الدمج بأنه حالة تهيؤ أو استعداد عام لاى المربين والمعلمين والعاملين مع المعوقين ولدى الواللدين والمجتمـع بصفة عامـة لتوفير تعليم الأطفال

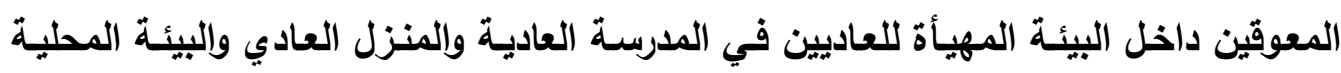

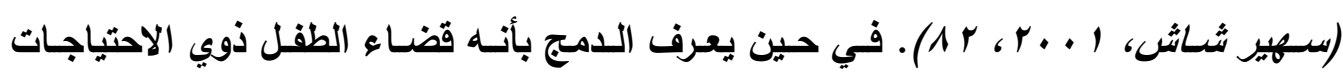

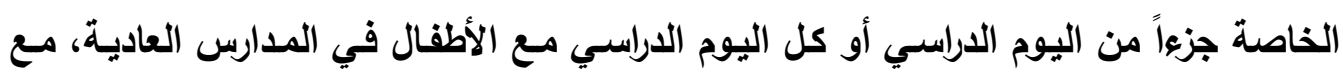

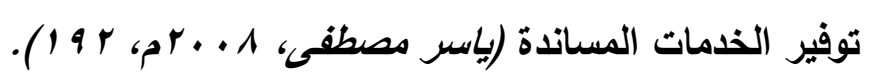

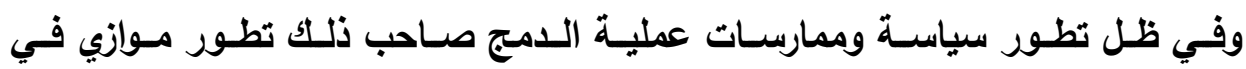
المصطلحات المستخدمة للإثـارة إليـه. ومـن المصطلحات المرتبطة بالدمـج: التكامـل، البيئة 
الأقل عزلا الوصـول إلى الاعتياديـة، مبـادرة التربيـة العاديـة... ولـم يعد الدمج التعليمي أو

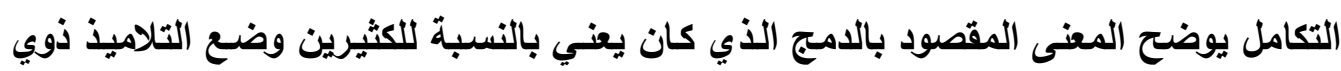

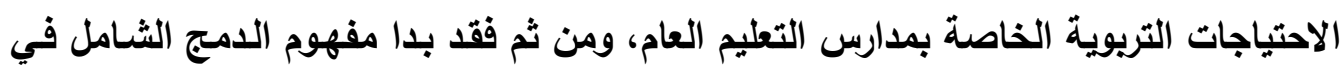

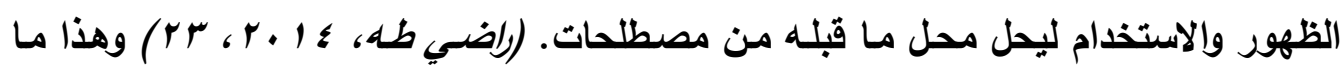

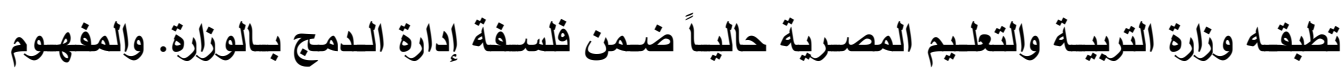

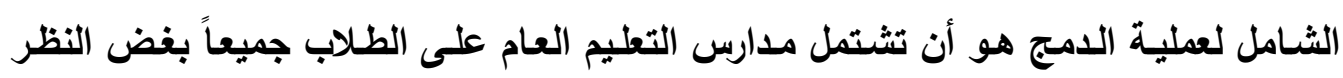

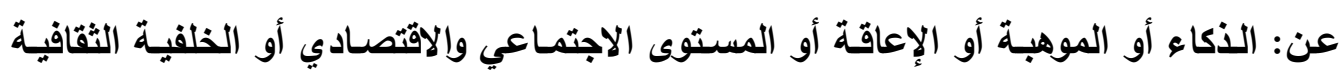

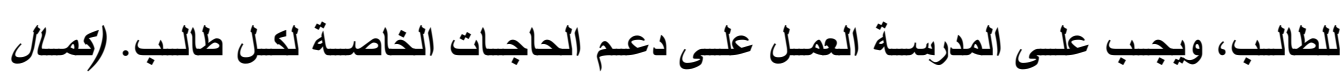

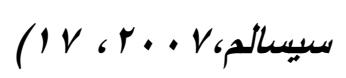

يتضح مما سبق أن الامج التعليمي يقصد به وضع المعاقين عقلياً مع أقرانهم العاديين

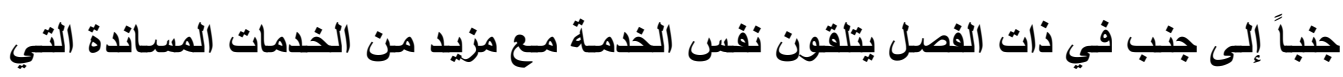

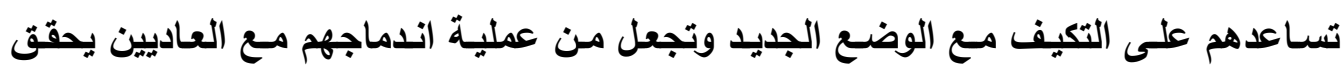

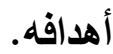

\section{( أهداق الثلمج الثمليمي)}

يساعد الدمج التعليمي على تعليم المعاقين عقلياً في بيئة بعيدة عن العزلة كما أنه يعمل على

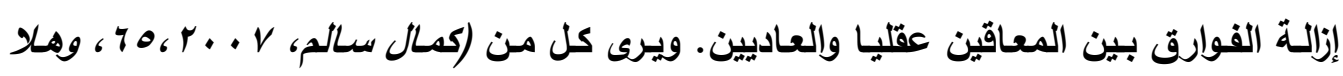

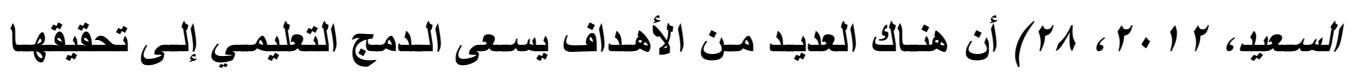
أهمها:

• إتاحـة الفرصـة لجميـع المعـاقين للتعليم المتكـافئ والمتســاوي مـع غيرهم مـن أطفـال

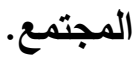

• إتاحـة الفرصـة لجميـع الأطفـال المعـاقين للانخـراط فـي الحيـاة العاديـة والتقاعل مـع الاخرين.

• إتاحة الفرصة للتلاميذ العاديين التعرف على التتلاميذ المعاقين وتقدير مشكلاتهم. • التقليل من التكلفة العالية لمراكز ومؤسسات التربية الخاصة. • التقليل من الفوارق الاجتماعية والنفسية بين الأطفال أنفسهم وتخليص الطفل وأسرته من الوصمة التي يمكن أن يخلقها وجوده في مدراس التربية الخاصة. 
• اعطاء المعاق فرصة أفضل لينمو نموا أكاديمياً واجتماعياً ونفسياً سليماً إلى جانب

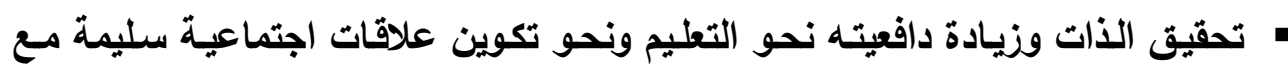
الغير وتعديل اتجاهات الأسرة • تخليص المعاق من جميع أنواع المعوقات سـواء الماديـة أو المعنويـة التي تحد من مشاركتهم في الحياة.

ولتجسيد دمـج المعاقين عقلياً بنجاح على أرض الواقع، هنـاك العديد من المتطلبات أبرزهـا:

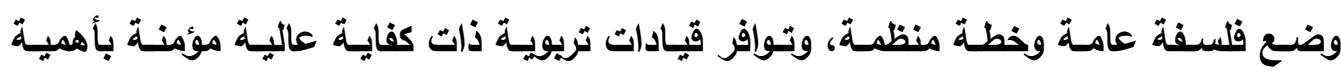

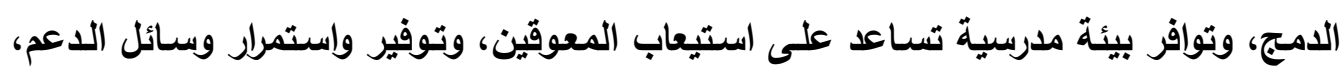

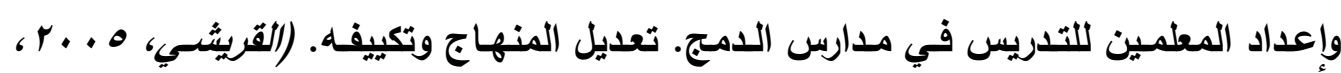

يتضـح ممـا سبق أن الهـف الأسـى من دمـج المعاقين عقلياً هو إزالـة الفوارق بين المعاقين عقلياً ويين أقرانهم العاديين وكذلك تغيير النظرة السلبية تجاه المعاق عقلياً من قبل هلئ

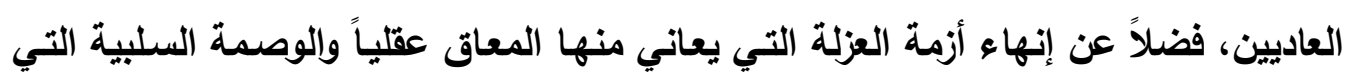

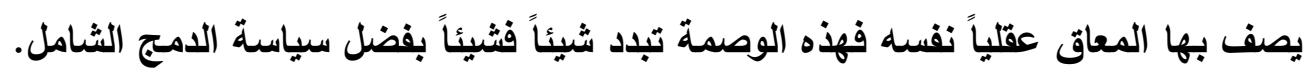

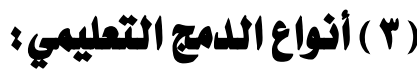

لامج المعاقين عقلياً أنواع وأشكال مختلفة تختلف باختلاف طبيعة ومستوى الإعاقة والأماكن التي طبق فيها والتجارب السابقة لعديد من الدول وهي كالآتي:

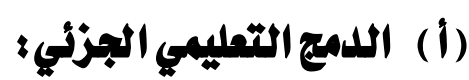

يقصد بـه دمـج الأفراد ذوي الاحتياجـات الخاصـة مـع أقرانهم العاديين في الفصول والمـارس العاديـة لبعض الوقت، اعتمـادا على نـوع الإعاقة وشـدتها ومسن ذلكت غرفـة المصـادر أمساكن

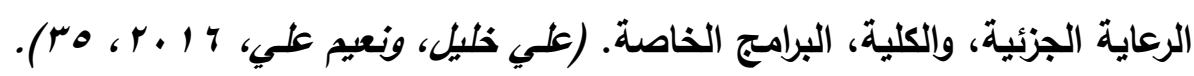

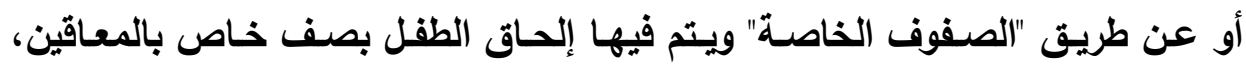

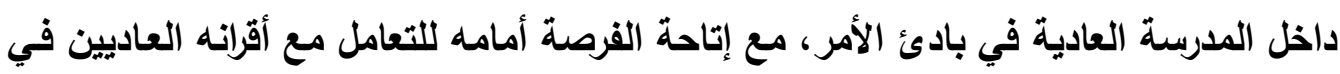

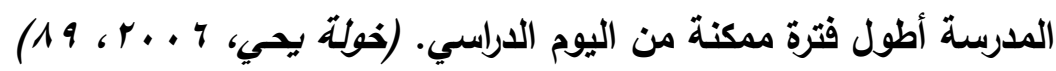




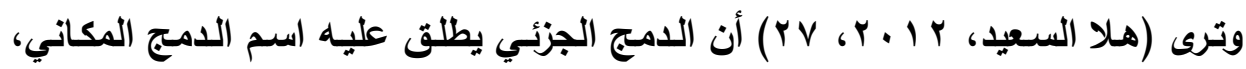

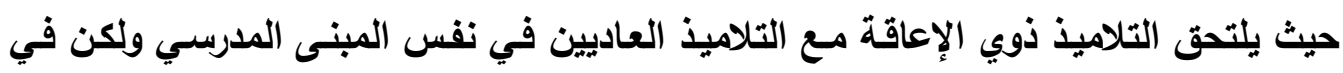

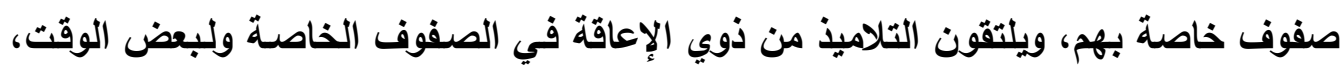

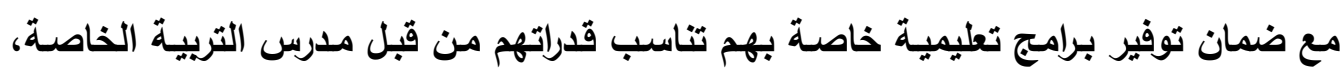
كما يتلقون برنامجا مشترك ا تعليميا مع التلاميذ العاديين في الصفوف العادية.

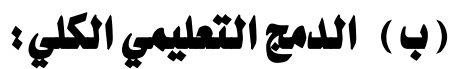

ويتضمن الدمـج التعليمي الكلي وضع الأطفال غير العاديين مـع الأطفال العاديين في

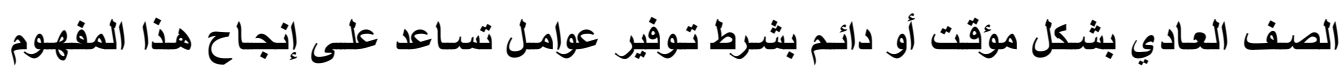

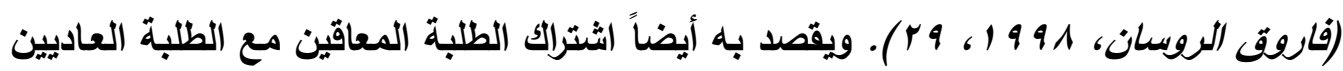

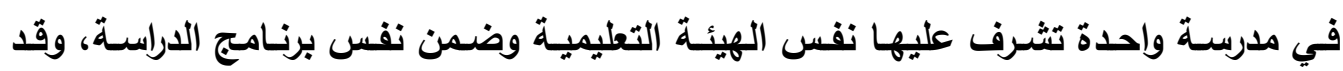
تقتضي الحالة وجود اختلاف في منـاهج الاراسـة المعتمدة، والأسـاليب والوسـائل المستخدمة.

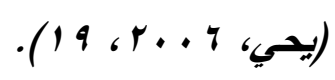

كما يشير مصطلح الدمج التعليمسي الكلي إلى تعليم الطلاب ذوي الإعاقات جنبا إلى الـ

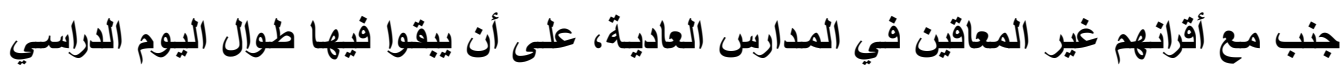

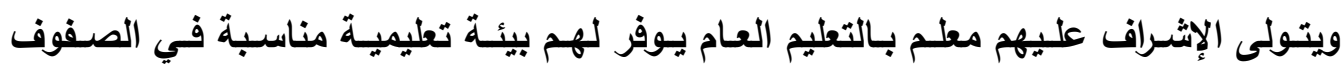

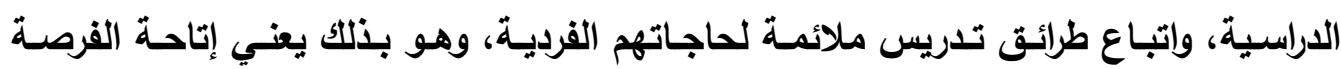
للطلاب ذوي الإعاقات من التواجد والانخراط في التعليم العام كإجراء يؤكد على مبدأ تكافؤه

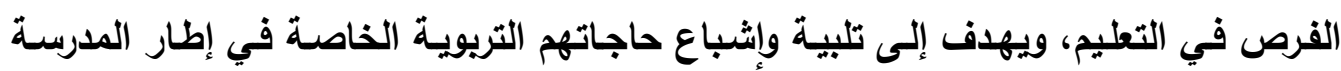

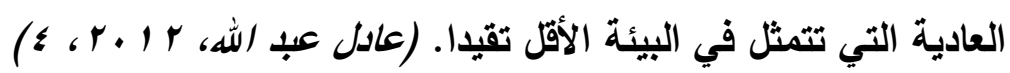

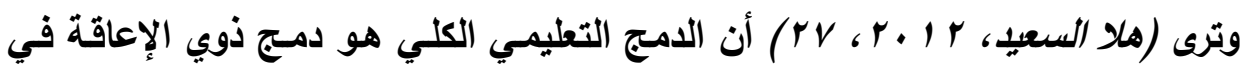

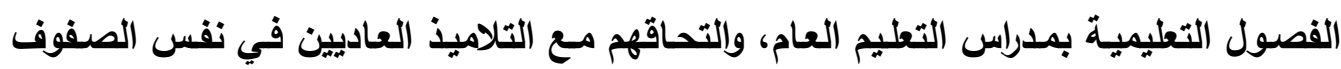
العادية طوال الوقت؛ حيث يتلقى هؤلاء التلاميذ برامج تعليمية مشتركة ويشترط في مثل هذا النوع من الامج توفير الظروف والعوامل التي تساعد على انجاح هذا النوع من الامج.

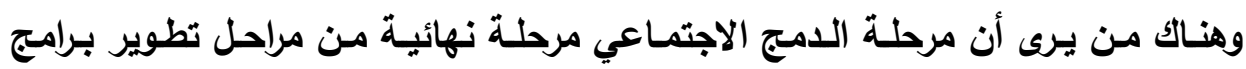
التربيـة الخاصـة للمعاقين، إذ أنها تعكس الاتجاهـات الاجتماعيـة الايجابيـة نــو المعوقين. 
ويقصد بذلك العمل على دمجهم في الحياة الاجتماعية. (مصطفى القش، وخليل المعايطة،

$(\leqslant 7, r \cdot 1 \leqslant$

وقد ظهرت مصطلحات الامج الشامل للإثـارة إلى عملية تعليم الطلاب المعاقين ضمن برامج التربية العامة، حيث يشير الدمج الشامل إلى مشاركة الجميع ضمن بيئة تريويـة عامـة

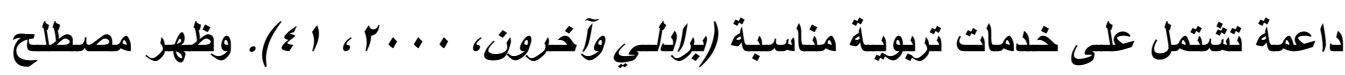
الامجج الشامل في بداية التسعينيات من القرن الماضي كرد فعل لضآلة العائد من وراء نظام

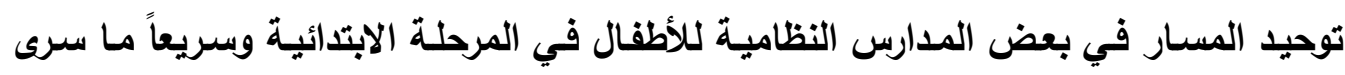

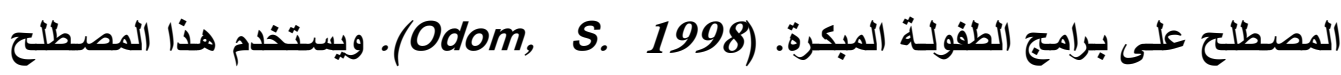

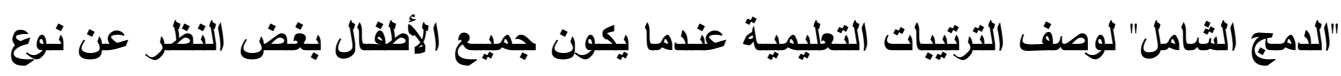
او شدة الإعاقة التي يعانون منها، يدرسون في فصول مناسبة لأعمارهم مـع أقرانهم العاديين الإنين

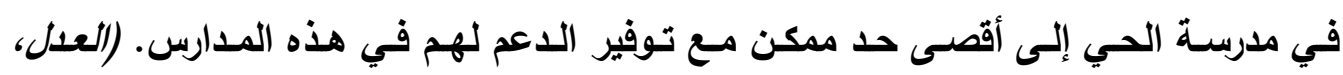
$(V \leq \leq, r \cdot 1 r$

يتضح مما سبق أن دمج المعاقين عقلياً يتخذ في مجمله شكلين إثنين الدمج الكلي أو

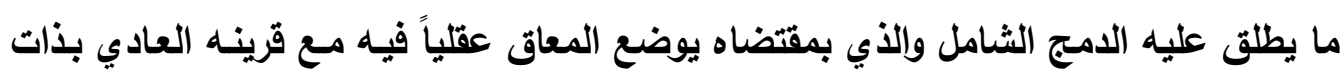

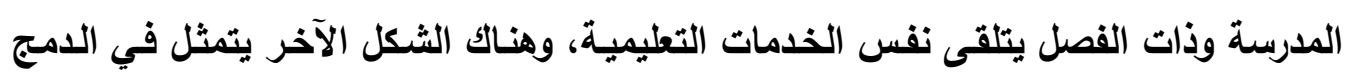
الجزئي ويكون فيه المعاق عقلياً بفصول ملحقة بمدارس التعليم العام ويمكن أن يكون دمجهم في حدود ضيقة تتمثل في بعض حصص الأنشطة الرياضية والفنية.

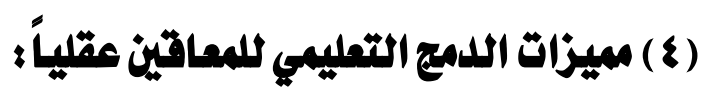

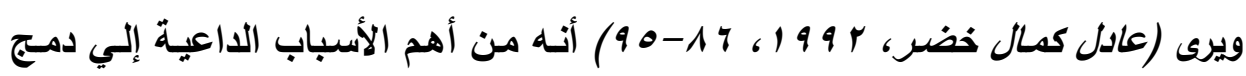
الأطفال المعاقين في المدارس العادية ما يلي: دمـج الأطفال المعاقين مـع العاديين في المـارس العاديـة يتماثـى مـع حقوق الإنسـان الأساسية، حيث أنـه يعترف بالمعاقين كأثـاص لهم حقوق ويقلّل من إمكانية النظر

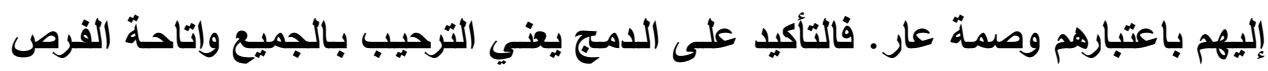
المتساوية للجميع، ووقف التمييز العنصري تجاه أولئك المعزولين. 
• في سياق التعليم للجميع ينبغي احترام ممارسـة الحق الأساسي في التعليم المعترف بـه

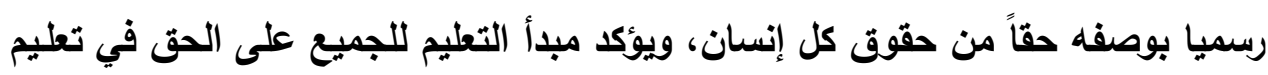
يناسب الاحتياجـات الفرديـة للأطفـال بغض النظر عن عن درجـة اعاقـاتهم أو احتياجـاتهم

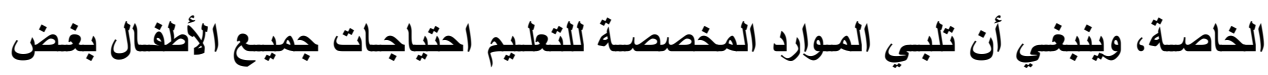

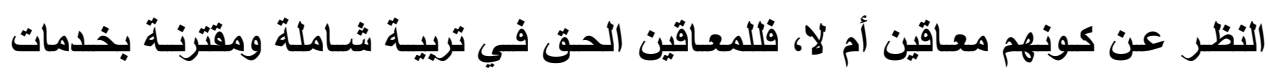

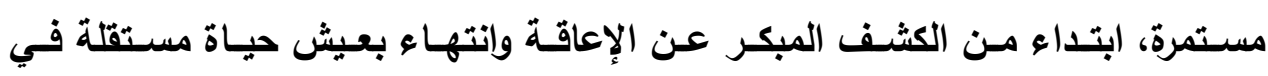
المجتمع. في الاشتراطات التعليميـة وإلمهنيـة لا يجب بالضـرورة أن نهون مـن البيئات المنعزلـة،

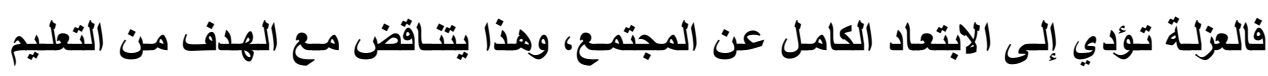

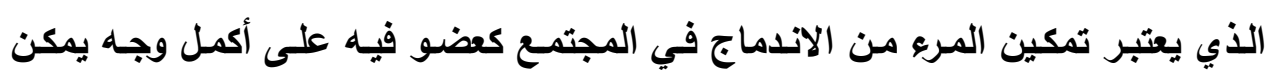
تحقيقه. إن حرمـان الأطفال المعوقين من فرص المشـاركة في نظم التعليم المدرسي العاديـة في

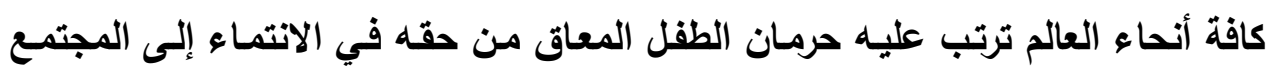

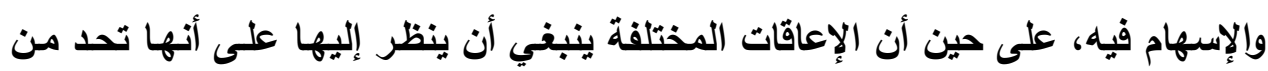

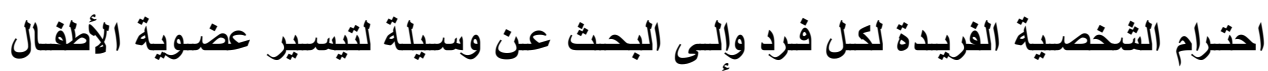
المعوقين في مدارسنا وفي المجتمع الأكبر.

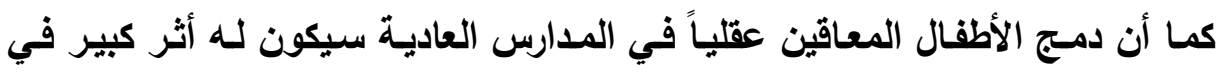

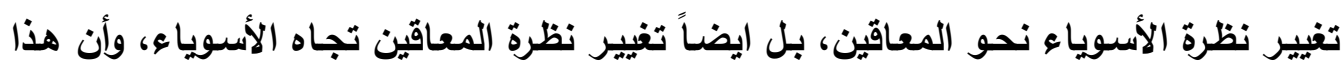

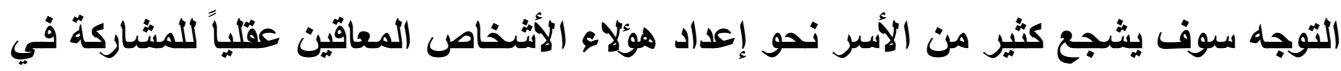

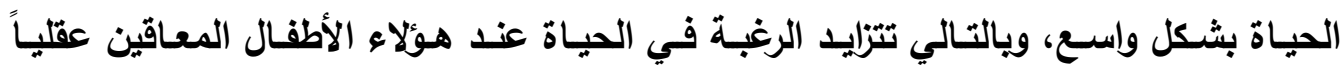

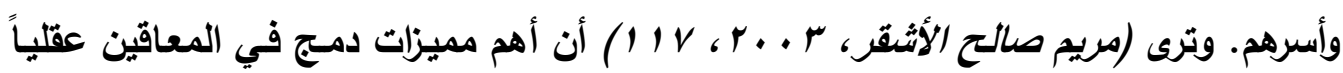
مع أقرانهم العاديين في المدارس العادية كالآتي: وجود الأطفال المعاقين مـع الأطفال الأسوياء في مبني والاحد أو في فصل فئل دراسي واحد

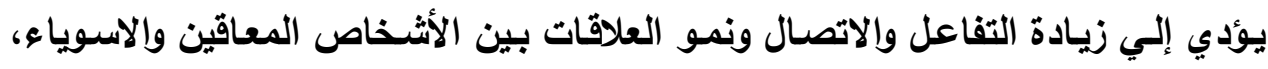
كما أن سياسة الدمج تتيح فرصة طيبة للطلبة العاديين كي يساعدوا أقرانهم المعاقين. 
• التعليم القائم على دمـج الأطفال المعاقين في المدرسـة العاديـة يزيــ من عطاء العاملين

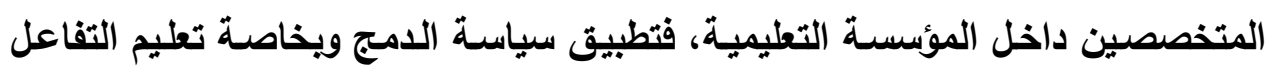
وأسـاليب الحوار بين المجموعات النظامية المتعددة، سيتيح للأطفال المعاقين الحصول على أقصى منفعة من المساعدة المتاحة لهم، من حيث التدريب على حل مشاكلهم.

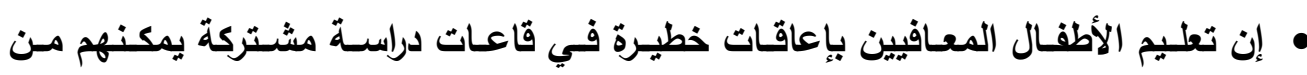
ملاحظة كيف يقوم زملاءهم الأسوياء بأداء واجباتهم المدرسية، وحل مشكلاتهم.

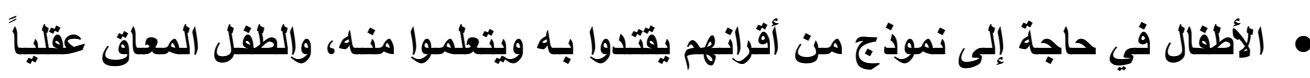
هو أحوج ما يكون لهذا النموذج، فيقوم بتقليد سلوكه، ويتعلم منه المهارات المختلفة.

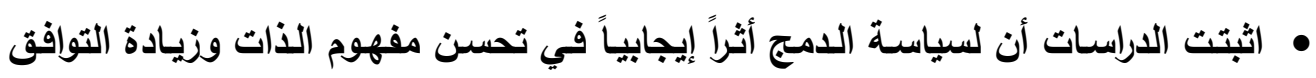

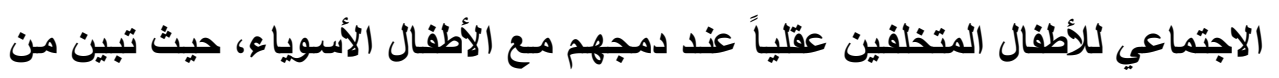

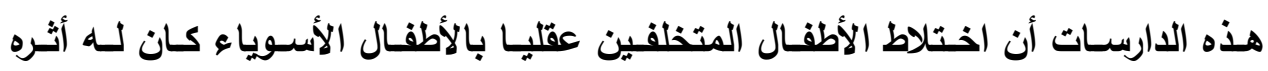
الإيجـابي في تحسن مفهوم المتخلفين عقليـا من ذاتهم، كمـا اتضـح أن دمـج الأطفـال المعاقين عقليا مع الأطفال الأسوياء في انشطة اللعب الحر أدى إلى الدماج الأطفال معاً في لعب جماعي تعاوني (تلقائي)، وإلي تزايد مضطرد في التفاعل الاجتمـاعي الإيجابي بينهما.

وللامج التعليمي للمعاقين عقلياً العديد من الفوائد التي تعود على الطالب المعاق عقلياً وكذلك

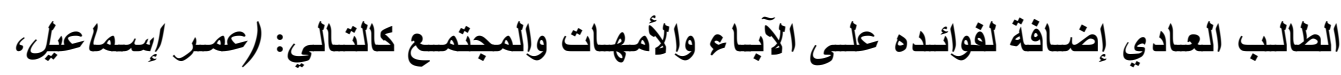
$(1+q-1+1,6+9$ فوائد الامج للطالب المعاق عقلياً: يكتسب الطالب المعاق عقلياً في فصول الدمج كثير من

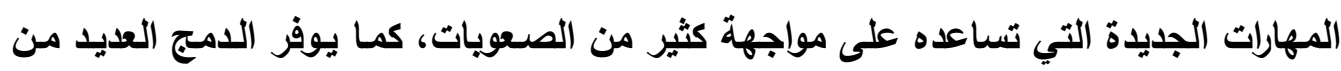

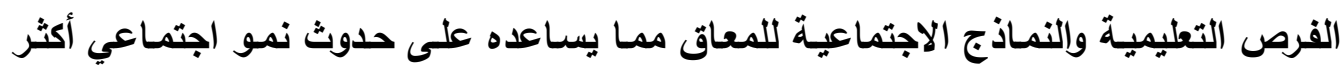

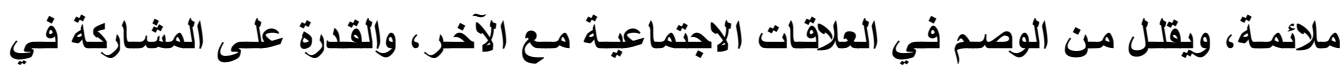

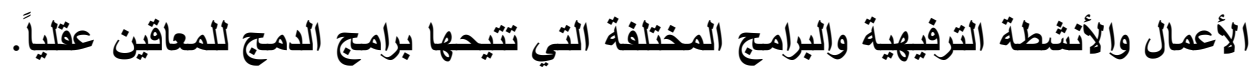
فوائد الدمج للطلاب العـاديين: يؤدي الدمج إلى تغير اتجاهـات الطالب العـادي نحو الطفل

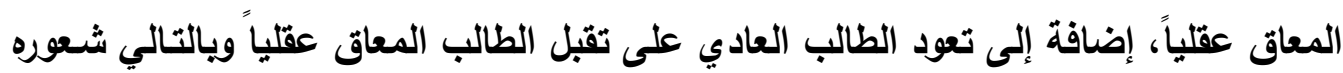
بالارتياح مع أشخاص مختلفين عنه. 
فوائد الدمج للآباء: يشعر نظام الدمج للآباء بعدم عزل الطالب المعاق عقليا عن المجتمع،

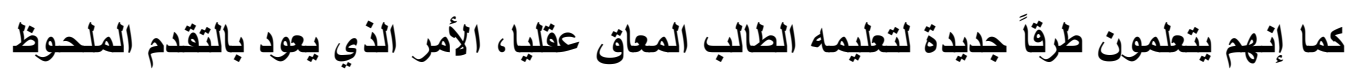

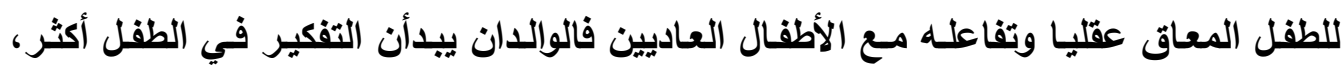

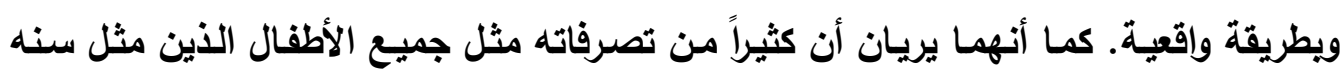
ويهذه الطريقة تتحسن مشاعر الوالدين تجاه طقلهما، وكنلك تجاه أنفسهما.

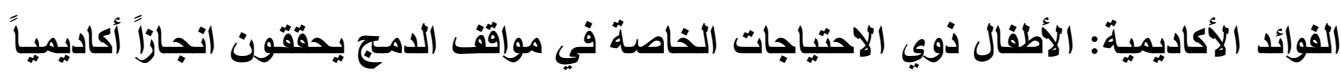

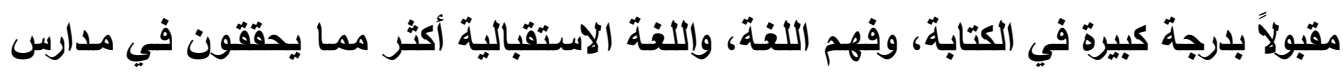

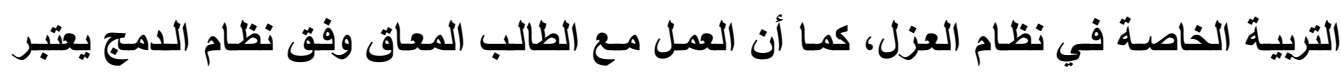

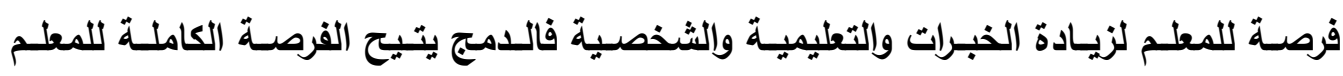
للاحتكاك بالطالب المعاق، والطريقة التي تستخدمها للعمل مع الطالب مفيدة أيضا ميع الطالب

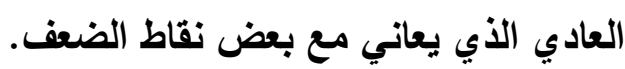

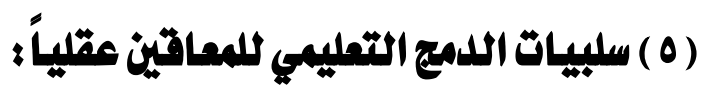

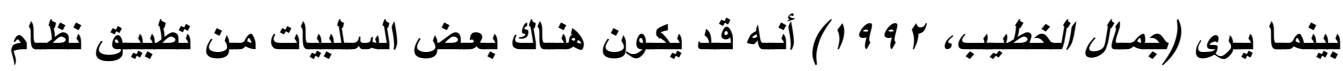

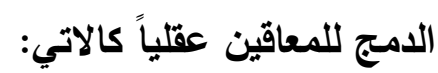

م يصبح الدمج في بعض الأحيان مضرا بالطفل المعاق عقلياً عندما يكون وجوده شكلياً

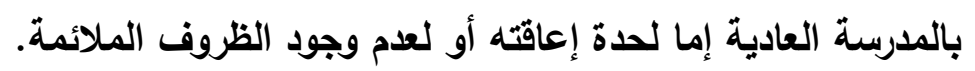

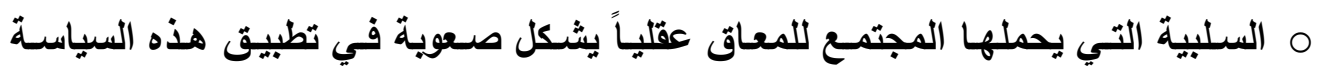
وتنفيذها.

م قد يؤدي الى الإحباط لدى المعاق عقلياً بسبب عدم القدرة على مجاراة الطلبة العاديين.

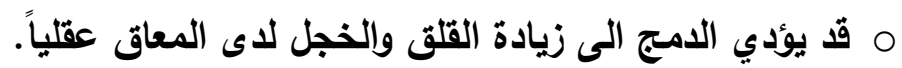
م قد يحدث في بعض الأحيان خلل أو فشل في النظام الإداري للمدارس العادية ممـا يؤدي بالضرورة إلى نتائج وخيمـة تضر بجميع التلاميذ داخل المدرسـة سواء العاديين منهم

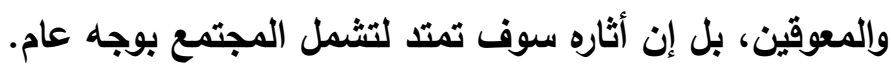

يتضـح ممـا سبق أن للامج التعليمسي للمعاق عقلياً العديد من المميزات بعضـها يعود

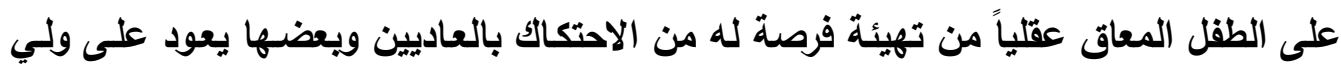


الأمر بأنه أتاح الفرصة لـه بأن تتحسن مشـاعرة تجاه ابنه المعاق بعد دمجه مـع العاديين،

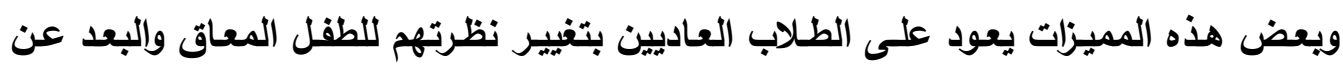

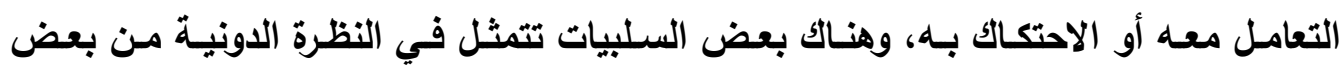
الأطفال العاديين تجاه الطفل المعاق عقلياً ونقص بعض الاهل الخدمات المساندة للمعاقين عقلياً والتي تكفل اندماجهم مع أقرانهم العاديين بثكل أمثل.

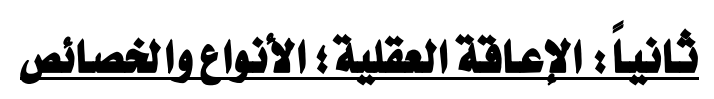
قُدمت للإعاقـة العقليـة في العقود الماضية تعريفـات عديدة واسـتخدمت مصططات

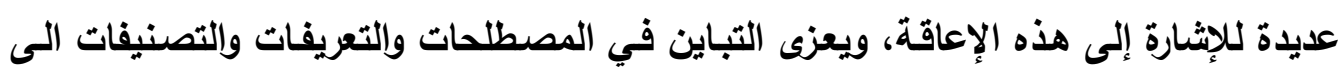

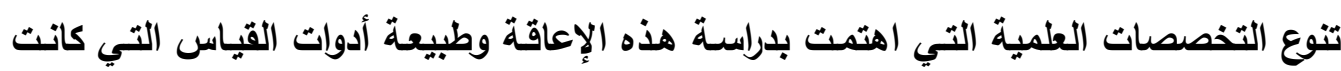

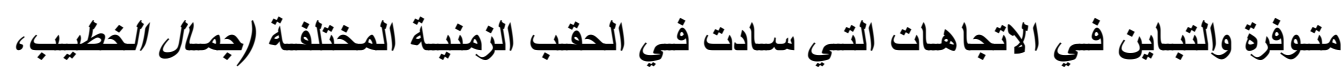

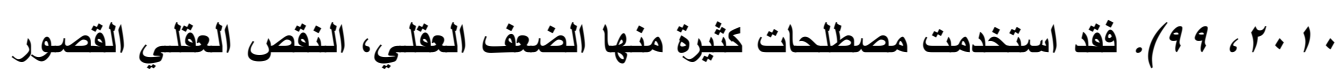

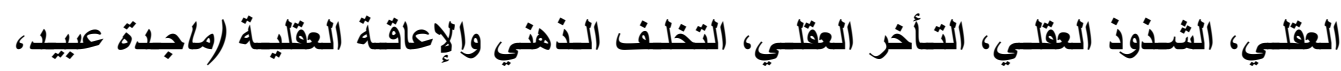

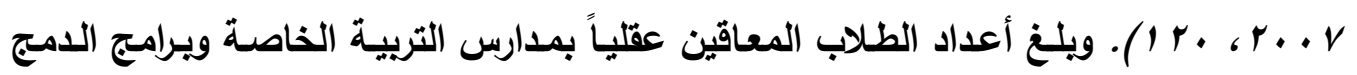

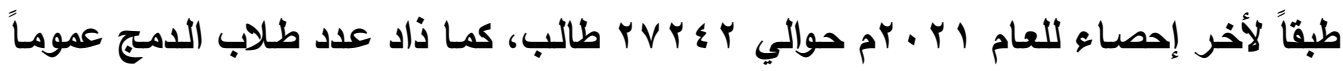

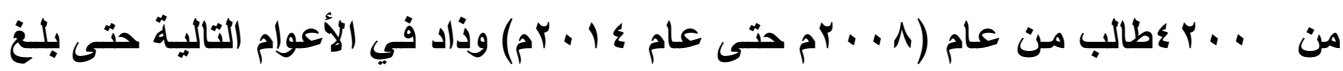

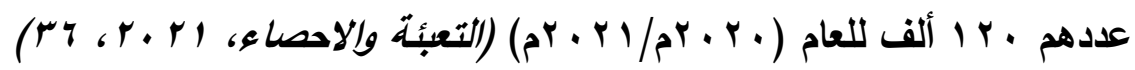
وقد غيرت الجمعية الأمريكية للتخلف العقلي اسمها الى الجمعية الأمريكية للإعاقات

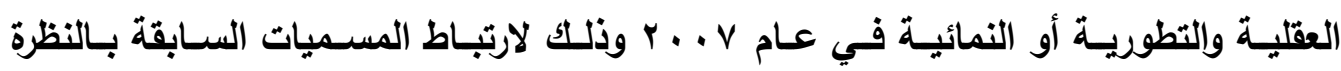

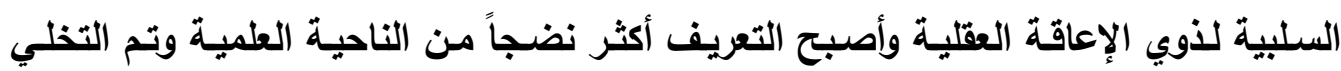

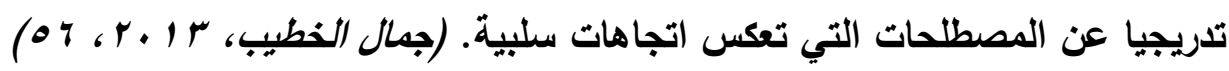

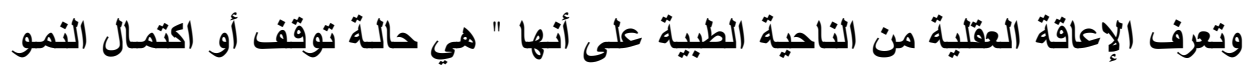

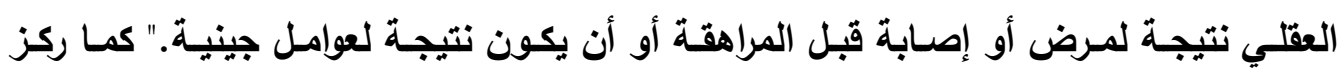

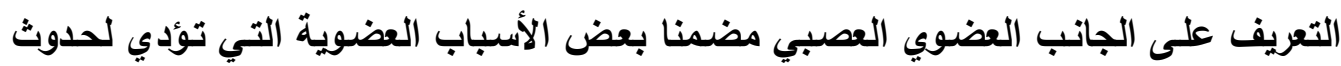

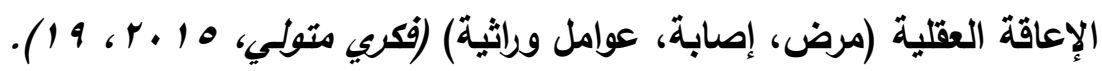
إن الإعاقة الذهنية "هي حالة من التوقف الذهني أو عدم اكتماله، والتي تتسم بشكل خاص بقصور في المها ا رت التي تظهر أثناء م ا رحل النمو، وتؤثر في المستوى العام 
للذكاء أي القدرات المعرفيـة، اللغويـة الحركية، الاجتماعية...الخ، وقد تحدث الإعاقة مـع أو باون اضطراب نفسي أو جسمي آخر'(السبي الشربيني، ؛ 1 . r ، و ه)

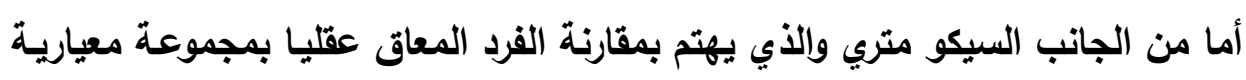

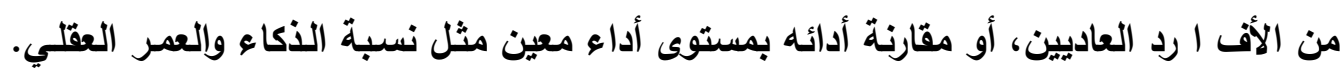

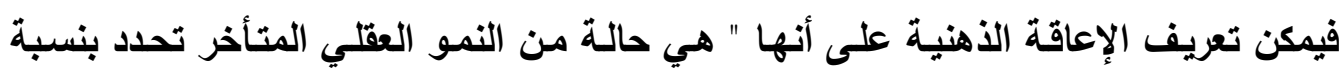

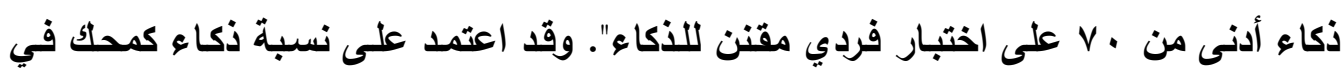

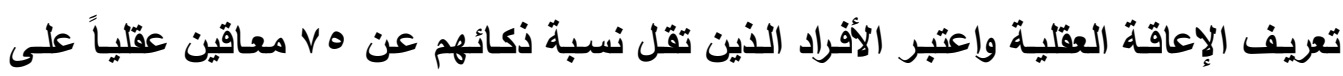

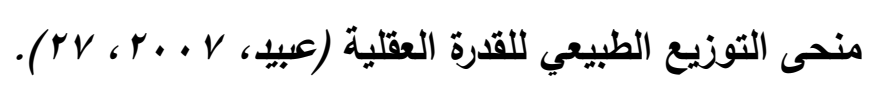

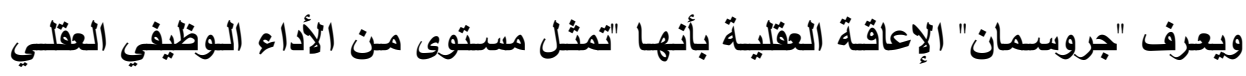

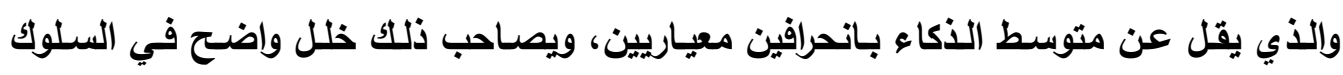

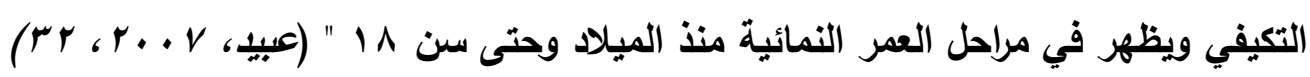

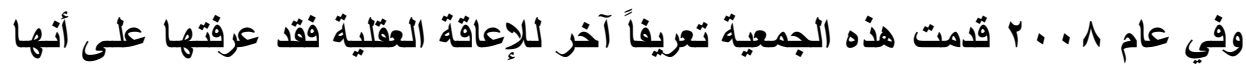
"هي إعاقة تتميز بانخفاض ملحوظ في كل من الأداء العقلي والسلوك التكيفي الذين يمثلان

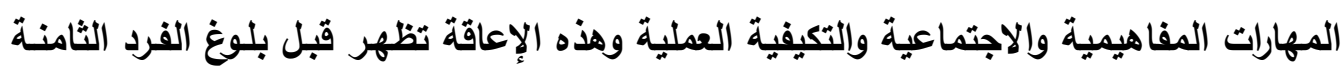

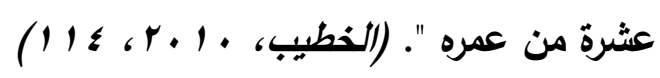

يتضـح ممـا سبق أن الإعاقة العقليـة لها عدة مفـاهيم فهنـاك من عرفها على أسـاس

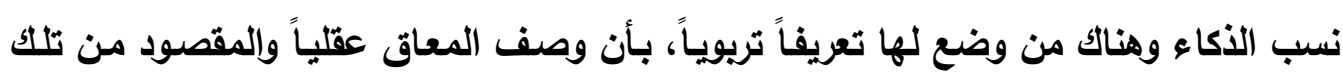

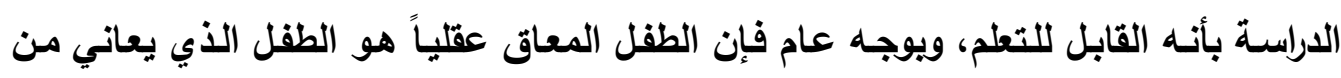

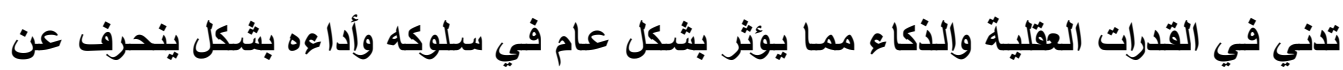
الطقل العادي.

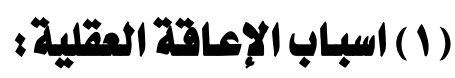

ذكـر المتخصصسون حتـى منتصـف القـرن العشـرين أن مسا نسـبته ( ـ 1: ه 1) \% حسالات

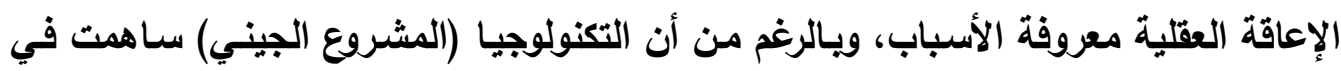

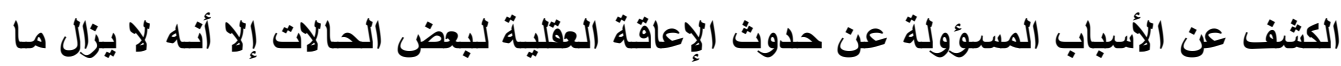


يقارب ه^ \% من الحالات لا زالت أسبابها غير معروفة. (-15 . Kauffman, J.2013)

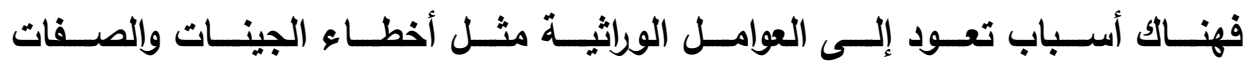

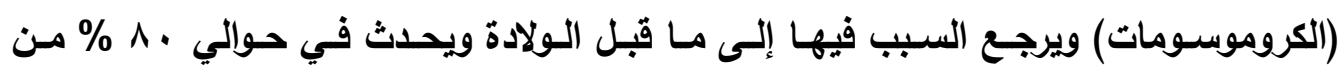

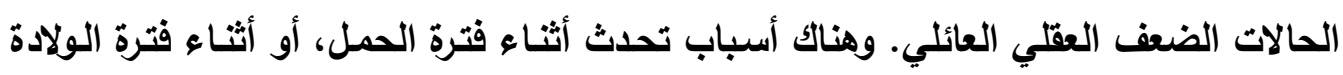

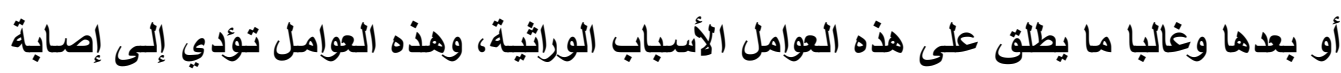

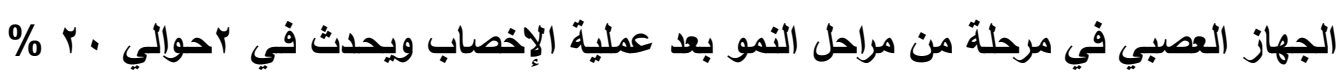

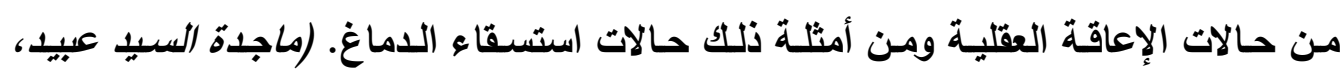
(109، r... 2.

ويقصــ بالعوامـل الوراثيـة تلـك العوامـل التكوينيـة الأصلية الداخليـة الناتجـة مـن فعل

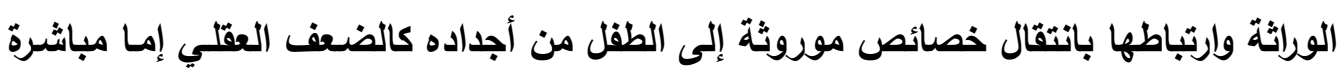

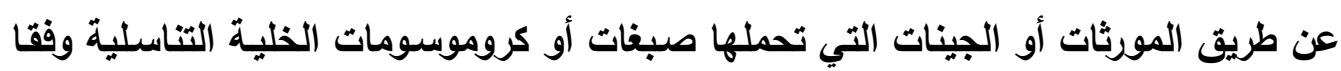

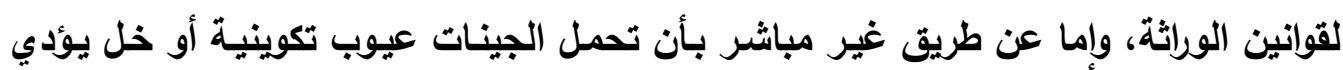

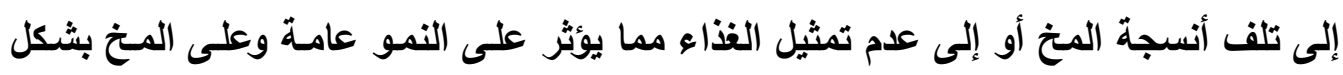

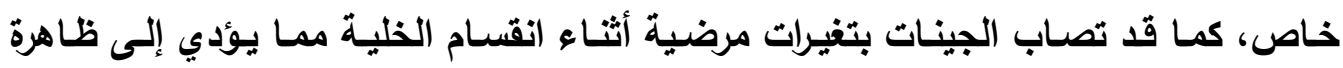
الإعاقة الذهنية الأمر الذي يحدو بنا إلى اعتباره نتيجة لأسباب منها العوامل الوراثية المذكورة

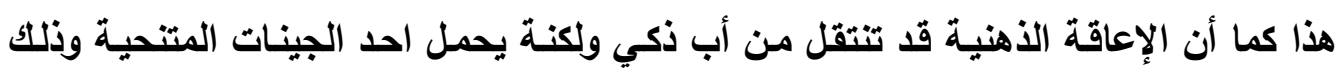

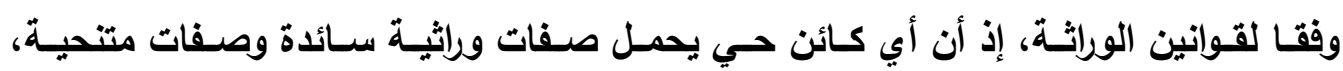
والصفات المتنحية لا تظهر في كل جيل، وذلك يفسر ظهور حالة الإعاقة الذهية في الأسرة العادية من حيث الأكاء وكان الاعتقاد قديما أن الوراثة هي المسئول الأول والأخير عن حالة والة

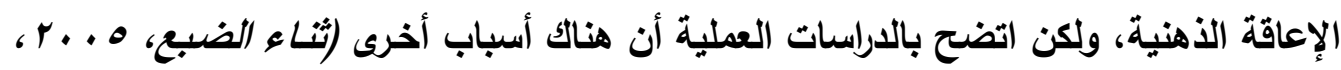

وهناك من يفسر العوامل البيئية بأنها عوامل قبل الولادة: وهي العوامل التي تؤثر على

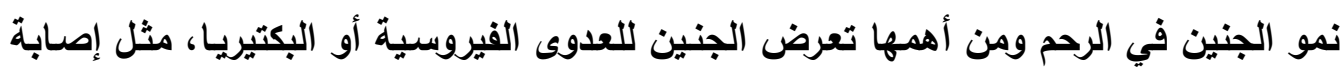

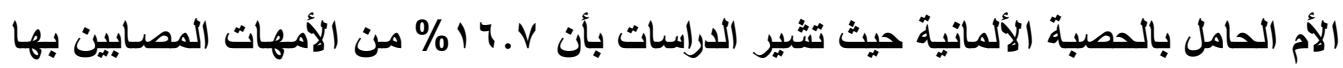

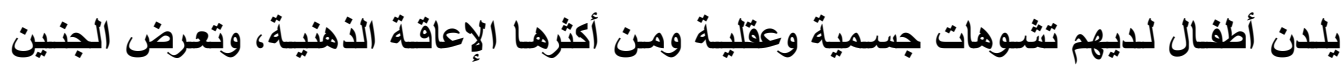


للإثـعاعات، أو استعمال الأدويـة المؤذيـة للجنين، أو تعرضها للحوادث والإصـابات الجسمية.

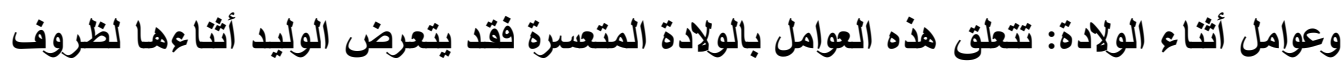

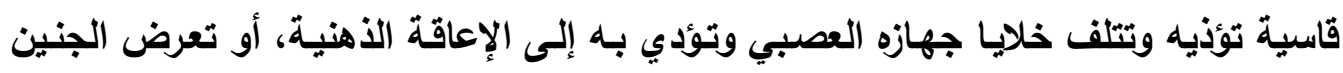

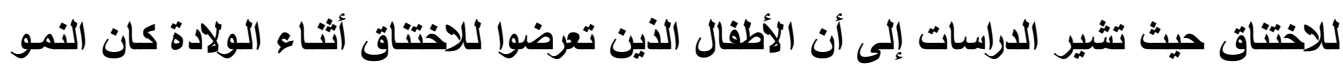

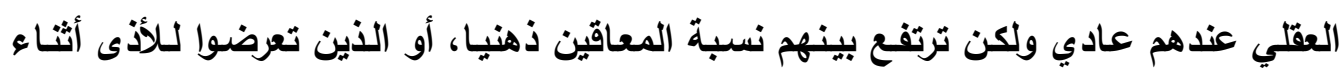

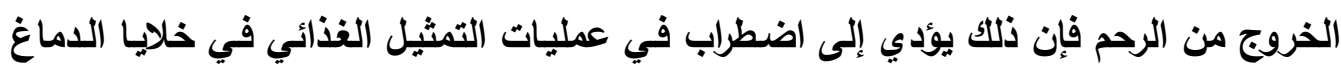

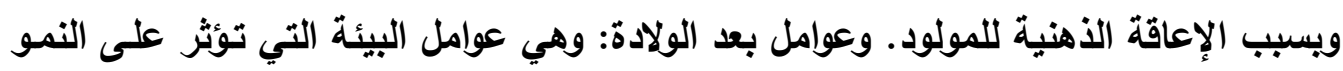

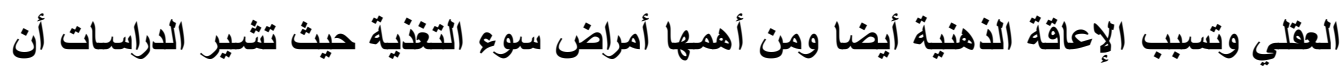

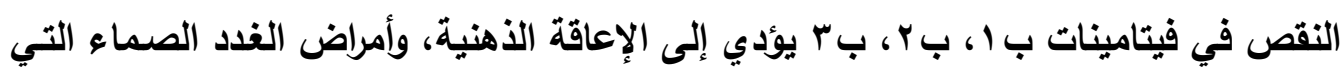

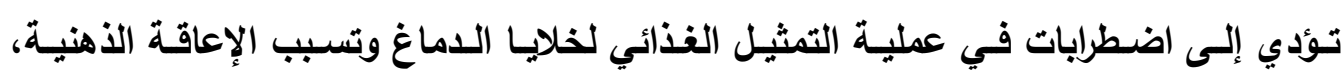

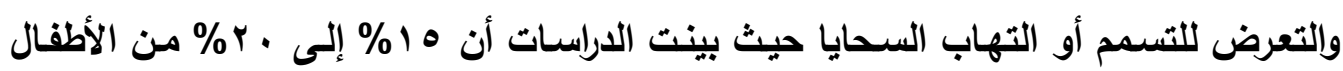

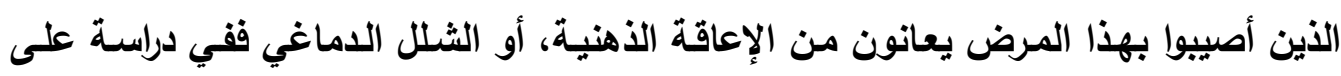
•

يتضح مما سبق أن الإعاقة العقلية لها أسباب متعددة قد تكون بسبب عوامل وراثية

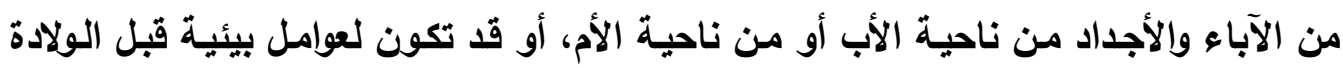

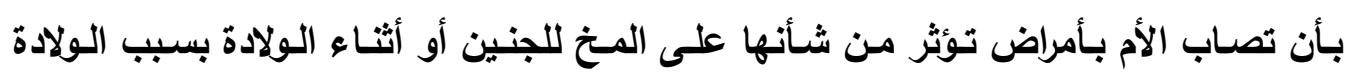

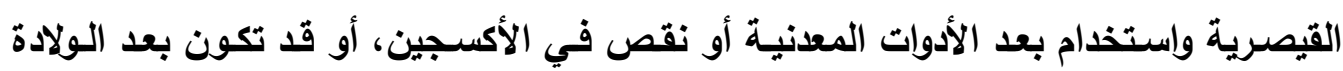
بسبب تعرض الطفل لحادث أو لأمراض شديدة كالحصبة الألمانية.

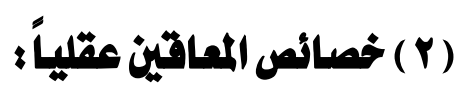

الخصائص الجسمية: لا توجد خصائص جسمية تميز الأثخاص المعاقين ذهنيا من الارجة البسيطة من أقرانهم العاديين، فالأشخاص المعاقين ذهنيا يشبهون العاديين إلى حد ما في كل

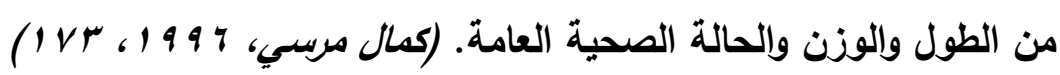
الخصائص العقلية: يختلف المعاقين ذهنيا عن أقرانهم العليين في النمو العقلي والقدرات العقلية والفروق بين حالات الإعاقة الذهنية البسيطة وأقرانهم العاديين في النواحي العقلية تكون بسيطة في مرحلة الطفولة المبكرة وكبيرة في مرحلة الطفولة المتوسطة وما بعدها، وأهم 
الخصائص العقلية التي تميز المعاقين ذهنيا عن أقرانهم العاديين هي البطء في النمو العقلي

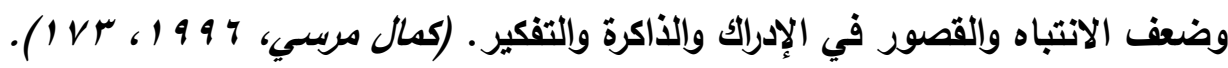
ويمكن التمييز بين الطقل المعاق عقليا إعاقة متوسطة والطقل العادي في النمو العقلي والقدرات العقلية في سن مبكرة، لأن نموه العقلي بطيء جدا وقدراته العقلية ضعيفة وحصيلته

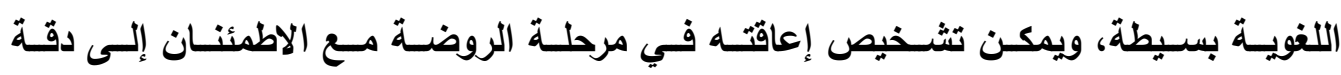

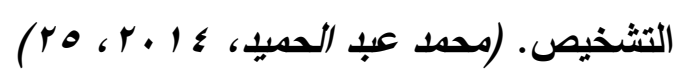

ومن أهم الخصائص العقلية التي تميز المعاقين عقليا عن أقرانهم العاديين البطء في هي هاءي النمو العقلي، ضعف الانتباه، القصور في الإدراك، والقصور في التفكير . ويتميز الانتباه عند

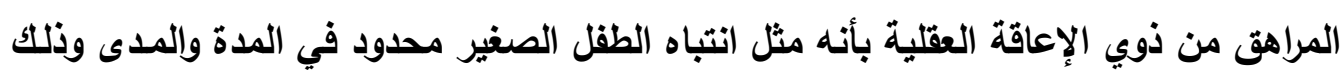

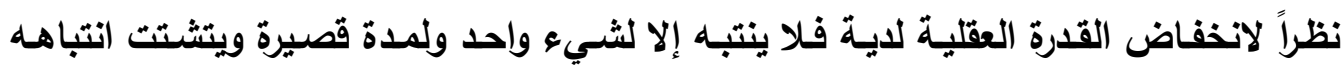

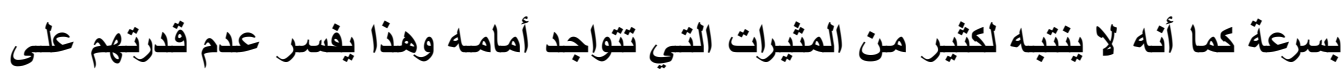

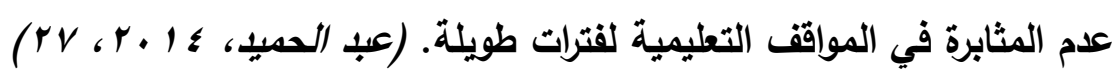
الخصائص الشخصية: إن الانخفاض في القدرات العقلية والقصور في السلوك التكيفي للى الأثخاص المعاقين ذهنيا قد يضعهم في موقف ضعيف بالنسبة لأقرتهم العاديين، فقد ينتج

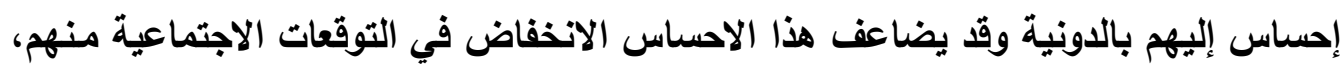
حيث أن الأخرين في معظم الأحيان يعاملونهم على أنهم مختلفين أو لا يتوقعون منهم الكثير

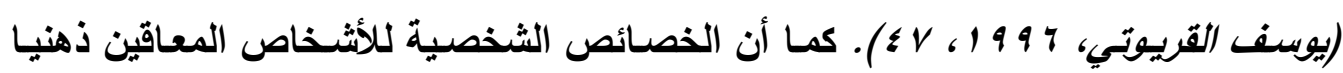
تتأثر بعوامل متعددة أسوة بتلك العوامل التي تؤئر في شخصية الأثخاص العاديين، ولكن نجد

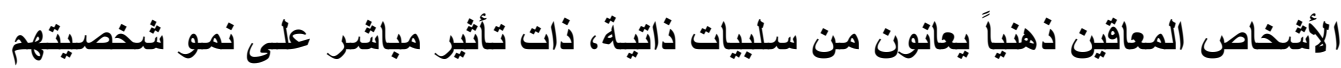

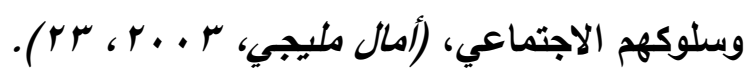

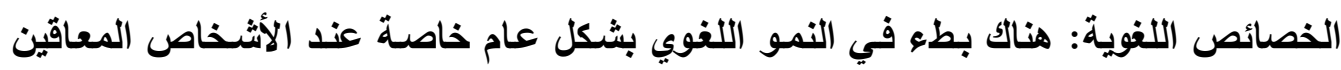

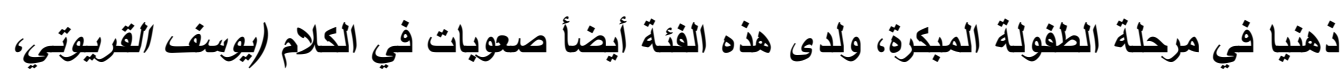

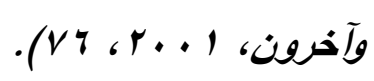

الخصائص الاجتماعية والانفعالية: أن التكيف الاجتماعي والانفعالي مرتبطان ارتباطا كبيرا مـع

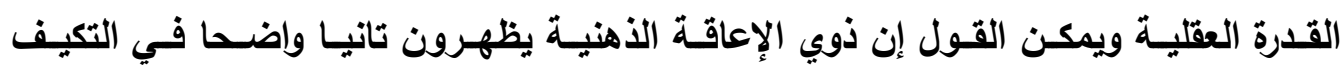


الاجتماعي ونقص في الميول والاهتمامات، وعدم تحمل المسئولية، والانعزالية، والعدوانية مـع

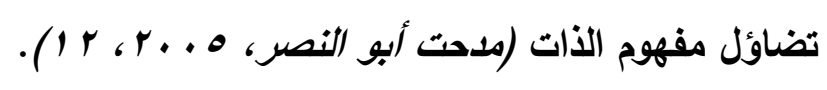

يتضح مما سبق أن الطقل المعاق عقلياً له خصائص متعددة سواء من الناحية الجسمية أو من الناحية الثخصية وسماتها، أو من الناحية اللغوية والقدرة على الكلام والتعبير، وجميعها

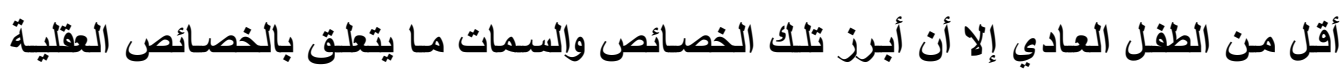

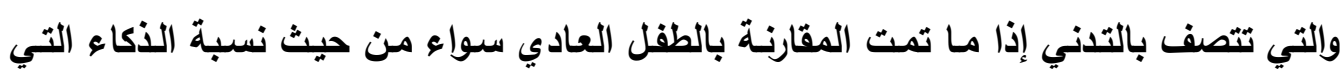
تصل في أحسن حالاتها إلى • V درجة أو في القدرات العقلية.

\section{(r) أنواعالإعاقة المثملية:}

وتقســ الجمعيـة الأمريكيـة للتخلف العقلـي الاعاقـة العقليـة هنـا حسب متغيـر القـدرة العقليـة والسـلوك التكيفي Adaptive Behavior حيث تؤخذ بعين الاعتبار في عمليـة التصنيف الي فئات الدرجة على مقياس الذكاء والدرجة على مقياس السلوك التكيفي ويشبه تصنيف الجمية الأمريكية إلى حد ما التصنيف حسب درجة الذكاء مـع التركيز على مظاهر

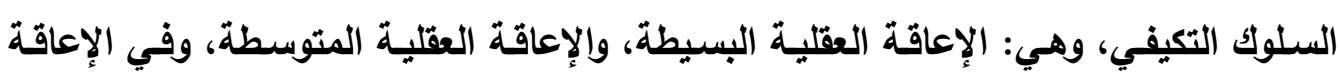

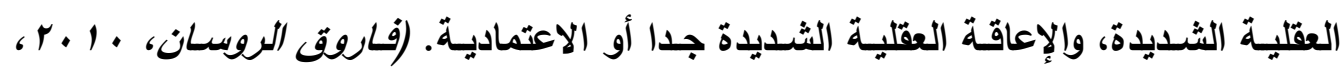

وهناك تصنيف للاعاقة العقلبة على حسب نسبة الأكاء كالتالي: الإعاقة العقلية البسيطة: وتمثل هذه الفئة ه^\% تقريبـا من المعاقين عقليا، وتتراوح نسبة

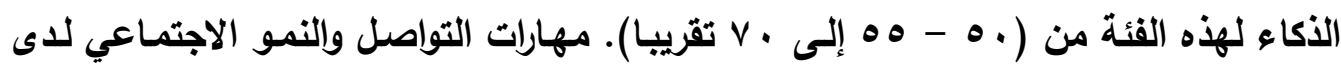

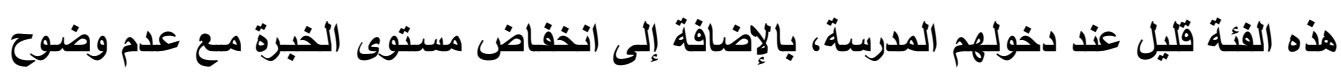
عيوب وظائف الإدراك مثل (النظر والسمع)، وهذا التأخر في وظائف الإدراك لا يمكن تميزه إلا عند دخولهم المدرسة، وهؤلاء الأشخاص يمكنهم أن يكتسبوا مهارات أكاديمية.

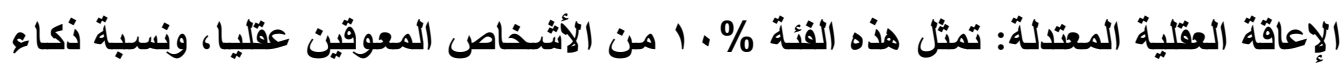

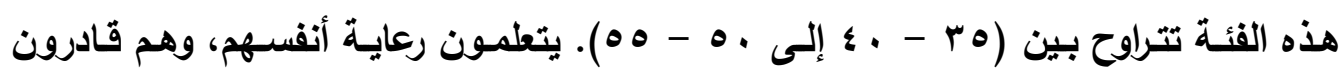
على القيام بمهارات أكاديمية. 
الإعاقة العقلية الثديدة: تمثل هذه الفئة من ب - ؛ \% تقريبا من المعوقين عقلياً وتتراوح

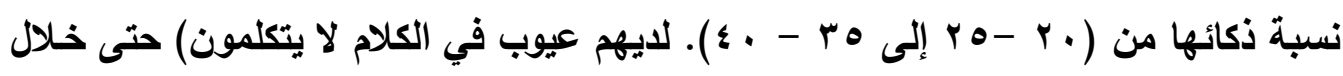

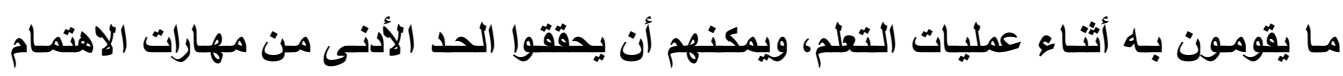
بالنفس.

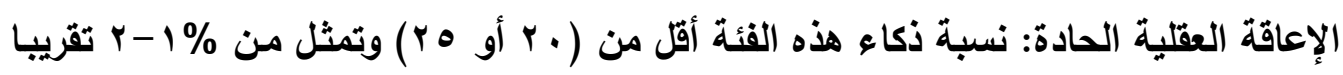
من المعوقين عقليا، لديهم مشاكل ملحوظة في الإدراك الحسي، وعجز شديد في نسبة الأنهاء الدهاء مما يجعل هناك صعويات شديدة في تعلمهم.

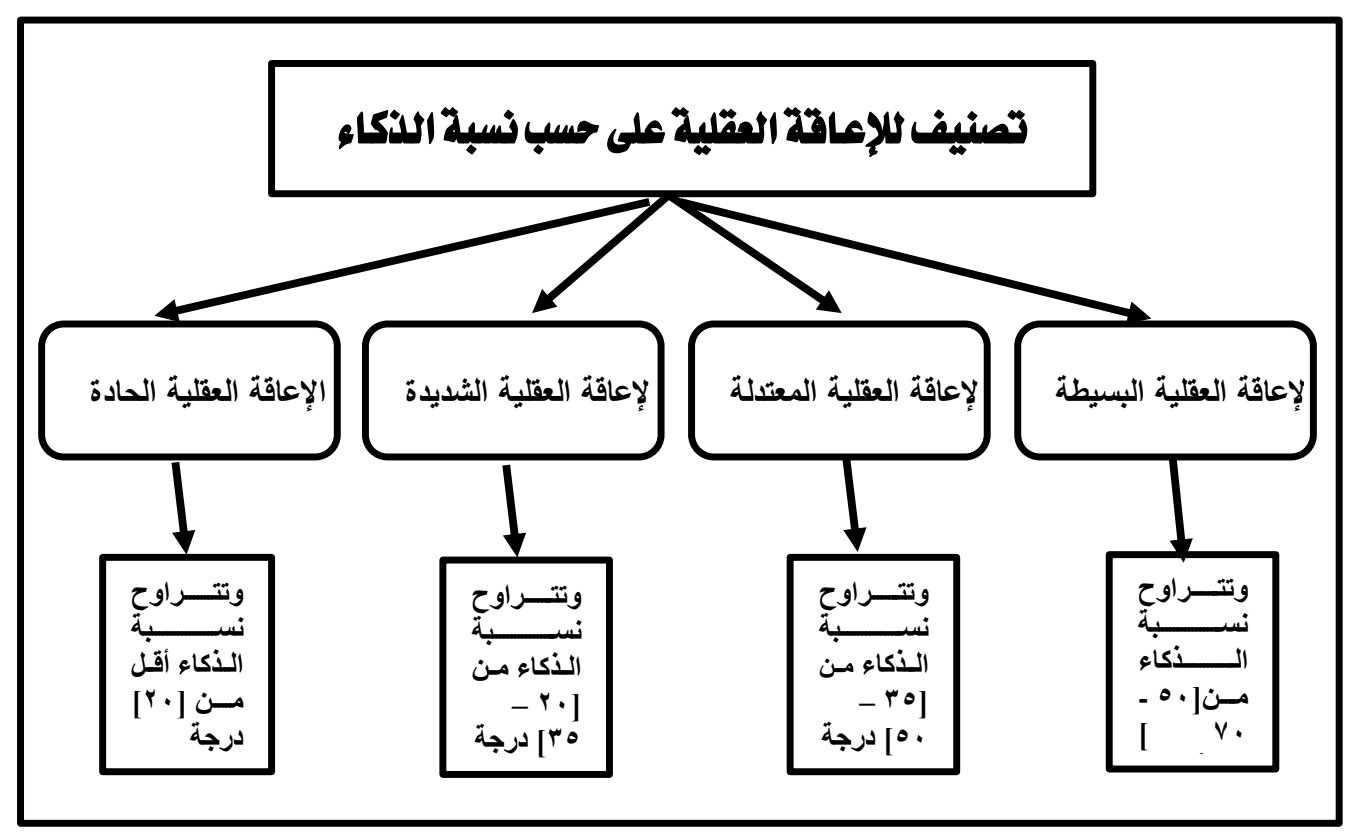

(شكل رقم (1) ) تصنيف للإعاقة العقلية على حسب نسبة الذكاء

ويتضح من الثكل السـابق أنواع وتصنيفات المعاقين عقلياً حسب نسبة الذكاء، وأن الأطفال المعاقين عقلياً المقصود دمجهم بمدارس التعليم العام هم الذين تتراوح نسبة ذكائهم

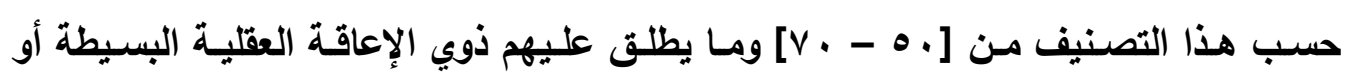

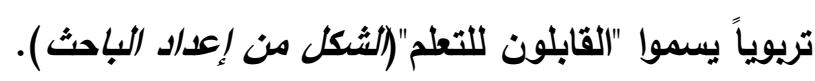
أما التصنيف التربوي فيمكن تصنيف الإعاقة العقلية فيه كالتالي: 


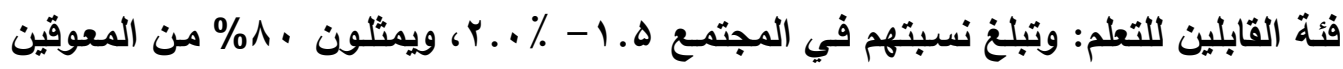

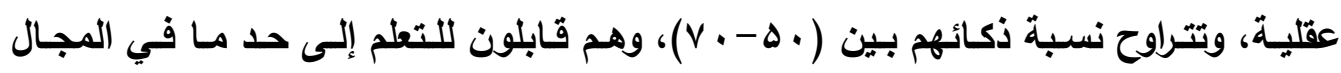

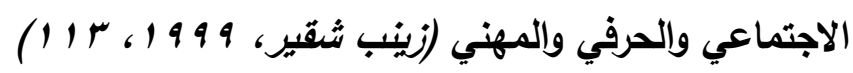

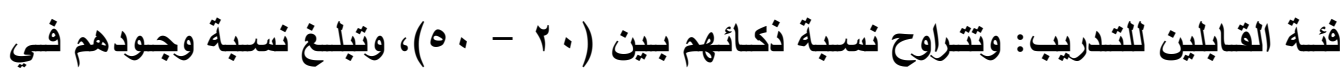

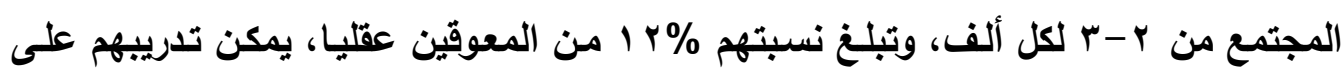

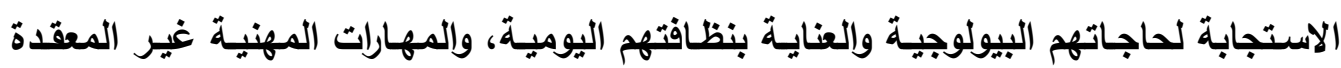

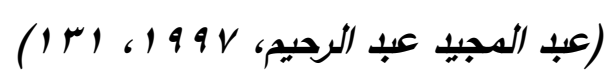

فئة المعتمدين: هذه الفئة غير قابلين للتعلم والتدريب، معدل ذكائهم يقل عن ب، وهم أقل النسب انتشـارا بين المعوقين عقليا وهي (\% 1)، غير قادرين على الاستفادة من التعلم في

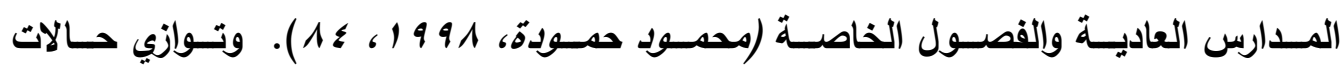

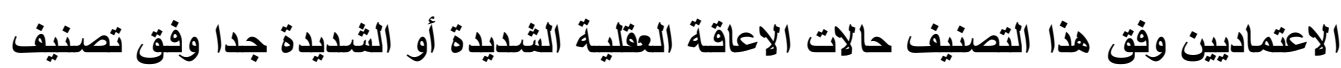

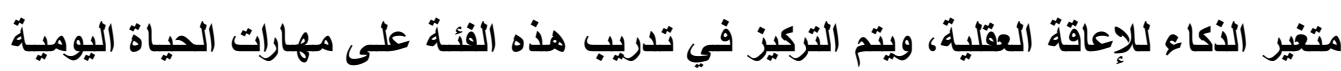

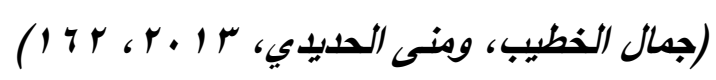

يتضـح ممـا سـبق أن هــاك تصنيفات متعددة للمعـاقين عقلياً، فهنـاك تصنيف يقسـم المعاقين عقلياً على أسساس نسبة الذكاء فيقسهم هذا التصيف المعاقين عقلياً إلى معاقين إعاقة بسيطة ومعاقين إعاقة متوسطة ومعاقين إعاقة شديدة، وهناك تصنيف تربوي يقسهر

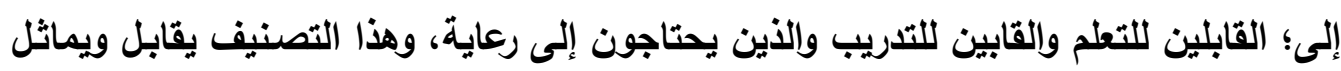
نفس التصنيف السيكو متري الذي صنفهم على أسساس نسب الذكاء، وأن المراد بهم في هذه وانه

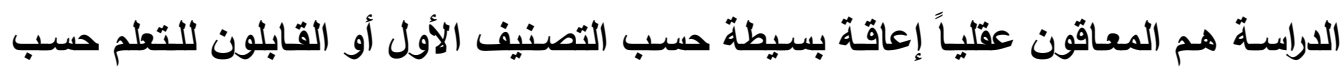
التصنيف الثاني وهو التصنيف التربوي.

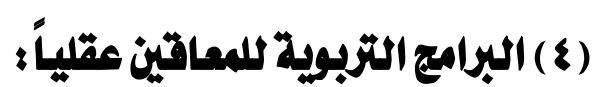

تركز البرامج التريويـة للأطفـال ذوي الإعاقـة العقليـة البسـيطة على أهداف وأسـاليب

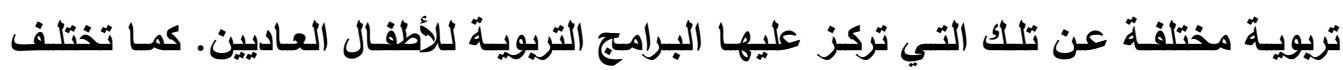

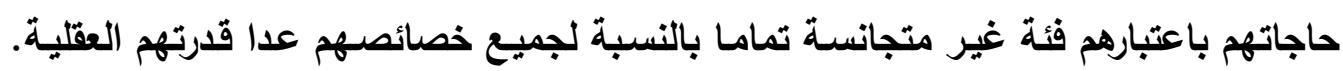

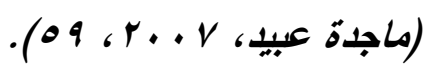


لكن معظمهم يتطلبون تربيـة خاصـة لتعلم المهارات الأكاديمية، ومهارات التواصل، والمهارات الحركية. كذلك فهم يحتاجون إلى مسـاعدة خاصـة لاكتسـاب المهارات الاجتماعية

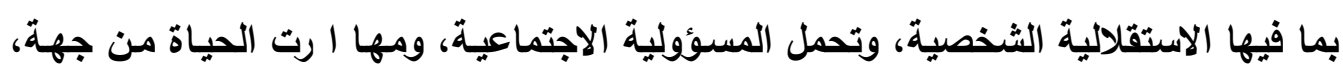

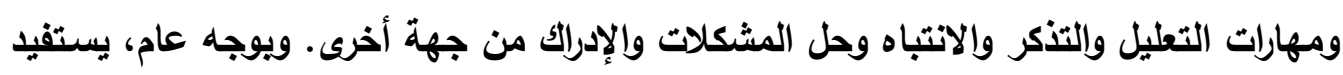

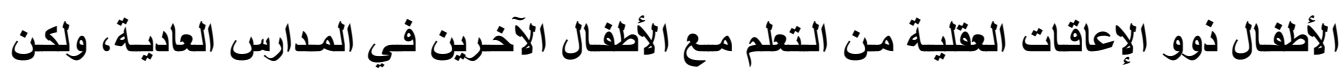
يصعب عليهم ذلك دون تقليم برامج إضافية داعمة لهم. فهم بحاجة إلى برامج تريويـة فرديـة.

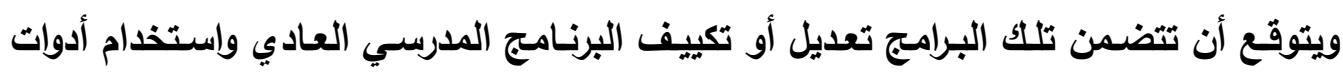

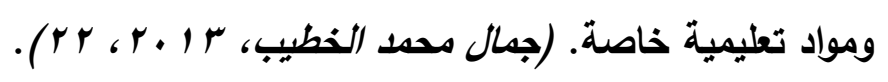

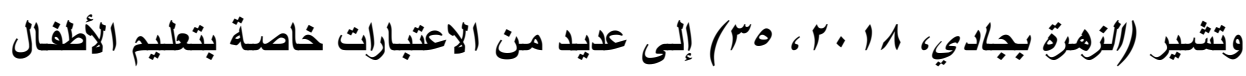

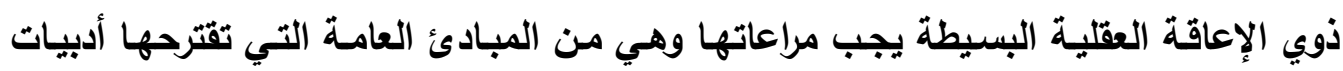
التربية الخاصة لتعليم الأطفال ذوي الإعاقة العقلية البسيطة كالاتي: • الفوز بانتباه الطقل للتركيز على المثيرات المهمة وتجاهل المثيرات غير الاعهية المهمة. • الانتقال تدريجياً من تعليم المهارات البسيطة إلى تعليم المهارات الأكثر تعقياً.

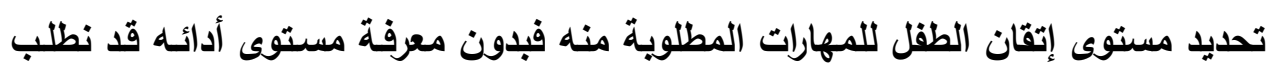
منه تأدية مهارات لا يسنطيع تأديتها أو قد تطلب منه تأدية مهارات يتقتها جيدا. • تعزيز الاستجابات الصحيحة للطقل، ويكون التعزيز فعالاً عندما يتم تتويعه.

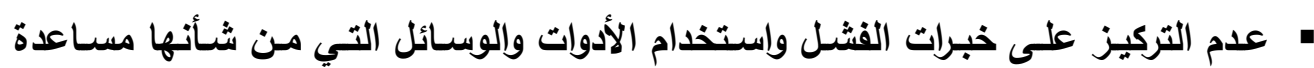
الطقل على تأدية المهمة المطلوية بنجاح. • استخدام المواد والأدوات الطبيعية في عملية التدريب كلما كان ذلك ممكنا.

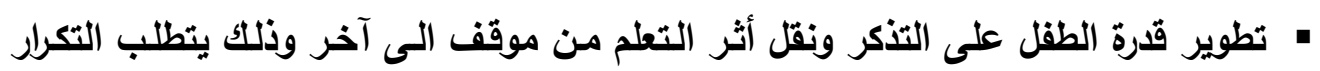
والإعادة لكي تصبح الاستجابة تلقائية. - توزيع التدريب وذلك يعني تدريب الطفل في جلسات قصيرة نسبيا تتخللها فترات اختبار

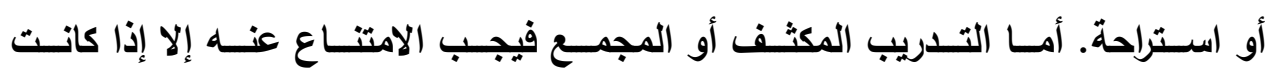
الاستجابات المطلوية من الطفل متشابهة إلى حد كبير. بn 
تأخرت مصر في تطبيق منظومسة الدمج للمعاقين عقلياً بمدارس التعليم العام، فقد خطت دول الخليج العربي خطوات جادة نحو دمـج المعاقين عقلياً بمدارس التعليم العام بدايةً بفصول ملحقة وإنتهاءً بالامج الثامل بمدارس التعليم العام.

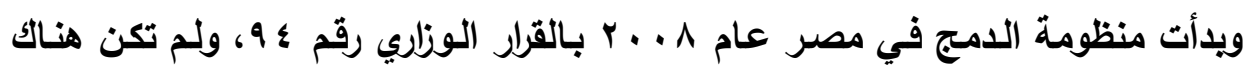

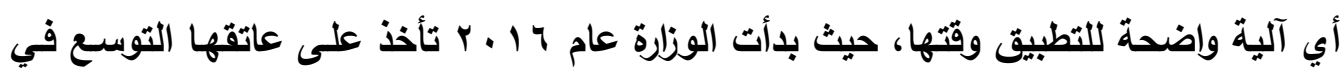

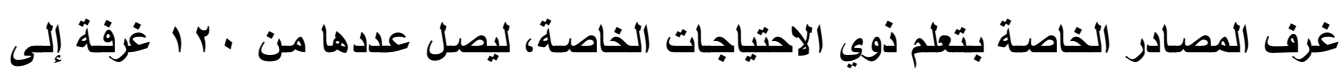

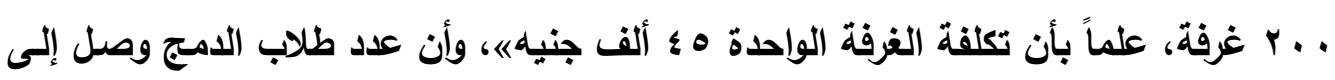

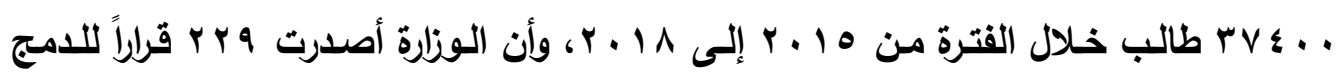
بالتعليم الفني، وما زالت تظمح إلى تدريب نحو أكثر من ـ 10 ألف معلم على كيفية التعامل

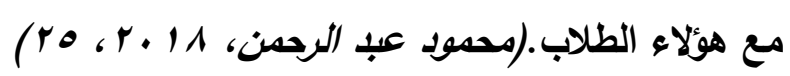

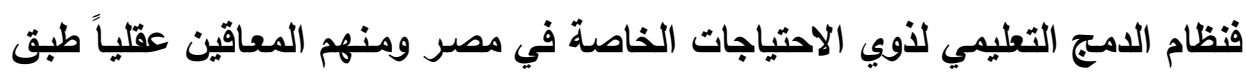

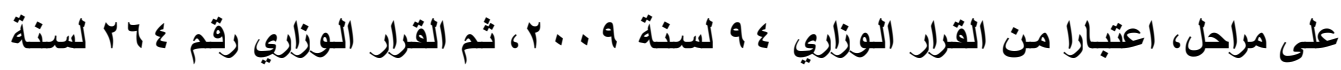
11

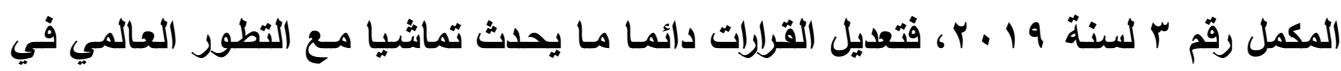
تقتيات التعلم العالمية لضمان الوصول لنتائج أكثر فاعلية.

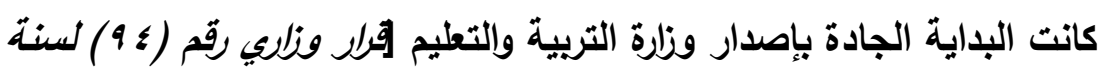

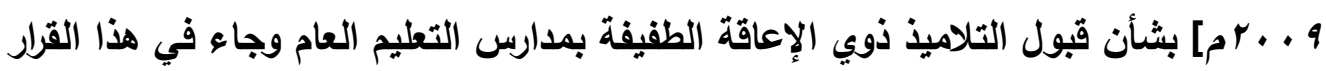
فيما يخص المعاقين عقلياً الآتي: ل يطبق نظام الامج للتلاميذ ذوي الإعاقة الطفيفة بالفصول النظامية بمدارس التعليم العام

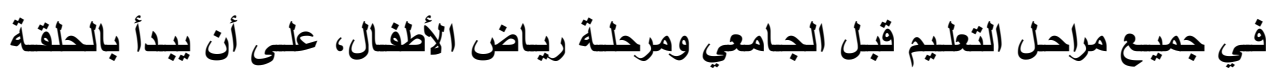
الابتدائية من التعليم الأساسي ورياض الأطفال.

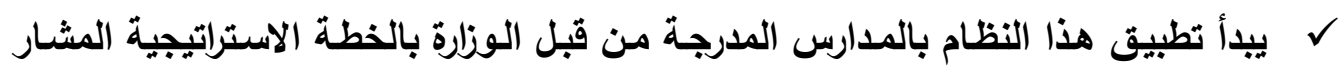
إليها، وذلك كمرحلة أولى.

يجوز لغير هذه المدارس من المدارس الحكومية أو الخاصة تطبيق نظام الدمج بها. ل في جميع الأحوال يجب على المدارس التي تطبق هذا النظام الإعلان عن ذلك داخل وخارج المدرسة. 
ل يشترط في الطقل ذي الإعاقة الطفيفة الذي يطبق عليه نظام الدمج المنصوص عليه في المادة الأولى من هذا القرار: ألا تكون إعاقته مزدوجة، ويشمل ذلك كف البصر والصم معاً، أو كف البصر أو الصم الأي تصاحبه إعاقة ذهنية. ألا تقل درجة ذكاء الطقل عن ب ه درجة باستخدام مقيـاس "ستا نفورد" بمراعاة الصحة النفسية للطقل، ونتائج اختبارات السلوك التكيفي. يكون إجراء التقييم الطبي والنفسي والتربوي على كل الأطفال المقبولين بالعام الدراسي الاسي الأول مـن المرحلـة الابتدائيسة من قبـل مكونـة مـن طبيب التـأمين الصـحي وممثل لإدارة

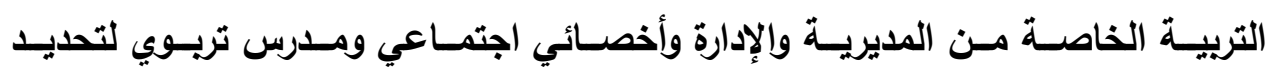
الاحتياجات والمعينات التريوية المساعدة على عملية الدمج.

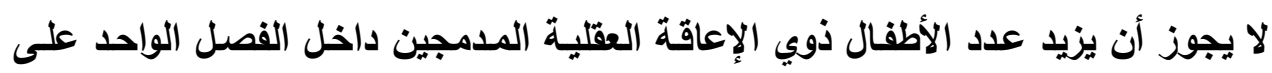
أربعة أطفال. - مون. يجوز تحويل الأطفال الذين تنطبق عليهم شروط الدمج من مدارس التربية الخاصـة إلى المدارس التي تطبق نظام الدمج المنصوص عليها في هذا القرار. يجب توفير الأنثطة الإثرائية والمكملة من غرف المصادر وغيرها داخل الإطار المدرسي

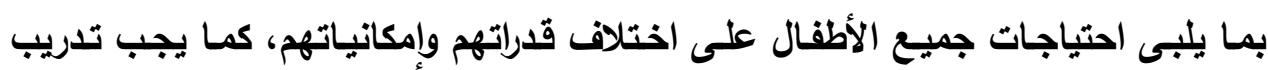
العاملين برياض الأطفال والمدارس من مدرسين وأخصائيين اجتمـاعيين ومديرين على الإنى متطلبات الامج وسياساته. ل للطفل ذي الإعاقة الحق في استخدام جميع الخدمات الاجتماعية والصـحية وإلنفسية

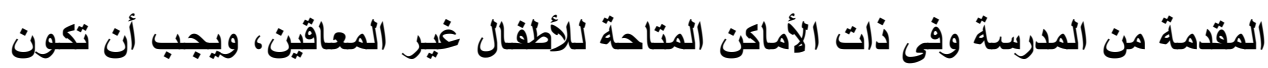

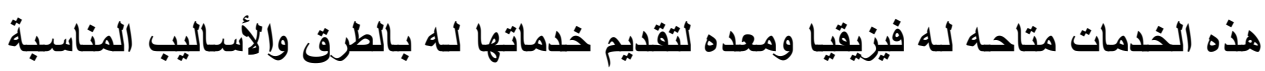
لنوع ودرجة إعاقته بما ينمى اعتماده على نفسه وييسر اندماجه ومشاركته في المجتمع

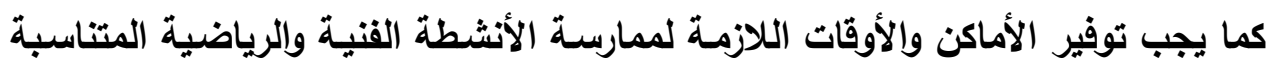

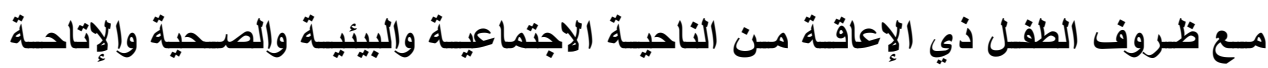

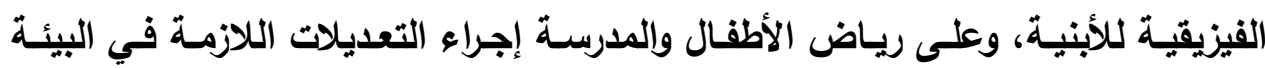


المدرسية من ناحية الوسـائل التعليمية وطرق التدريس ووسيائل التقييم وغير ذلك من الإجراءات التي تيسر الامج على ألا يشكل التعديل اللازم عائقا لامج الأطفال. يتم تقويم التلاميذ المعاقين المدمجين بحسب نوع الإعاقة طبقا لمـا تحدده الإدارة العامـة

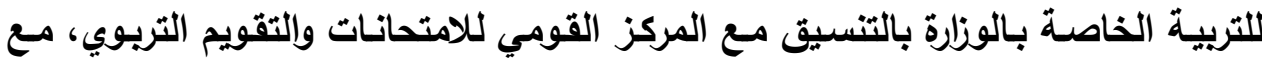
مراعاة توفير المعنيات التريوية لأداء كافة أنواع التقويم. ويكون صرف الحوافز للمعلمين في الفصول التي يوجد بها تلاميذ معاقين مدمجين في ردي ضوء الأداء والإمكانيات المتاحة. يكون الإشراف على التلاميذ المدمجين برياض الأطفال ومدارس التعليم العام من قبل الإدارة العامة للتربية الخاصة والتعليم الابتدائي ورياض الأطفال بلديوان الوزارة بالاشتثراك

مع الإدارات المختصة بمديريات التربية والتعليم بالمحافظات والإدارات التابعة لها. ل يطبق في شأن التلاميذ ذوي الإعاقة المدمجين بالمدارس التي تطبق نظام الدمج - في

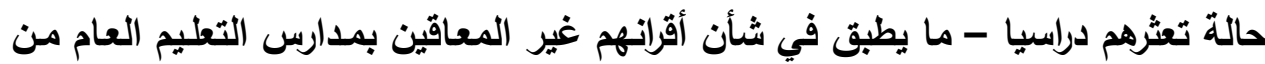
لوائح وقرارات.

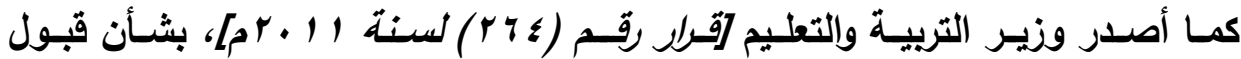
التلاميذ ذوي الإعاقة البسيطة بالمدارس التي يتم تهيئتها للامج بالتعليم العام وكانت مواده فيما يخص الإعاقة العقلية كالاتي: يطبق نظام الامج للتلاميذ ذوي الإعاقة البسيطة بالفصول النظامية بمدارس التعليم العام الحكوميـة وإلمـارس الخاصـة، والمـدارس التـي تـدرس منـاهج خاصـة في جميـع مراحل التعليم قبل الجامعي ومرحلة رياض الأطفال، في المدارس التي سبق تجهيزها للامج في السنوات السـابقة وفي المدارس التي يتم اعدادها وفقا لخطة الوزارة في تهيئة وإعداد المـارس لاسـتيفاء متطلبـات دمـج ذوي الإعاقـة البسيطة بمـارس التعليم العـام؛ ويمـا يختاره ولـي أمسر الطفل ذو الإعاقـة في إلحساق طقله بمدرسـة داءمجـة أو مدرسـة تربيـة

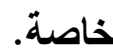
• وتلتزم المدارس التي تطبق هذا النظام بالإعلان عنه داخل وخارج المدرسة.

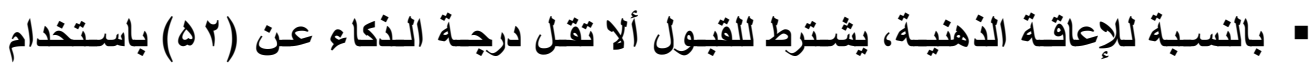
مقياس ستانفورد بينية (الصورة الرابعة) مع مراعاة الصفحة النفسية Psychological 
page تكون الإعاقة مزدوجة بالنسبة لأي من الإعاقة البصرية أو السمعية أو الذهنية (مثل:

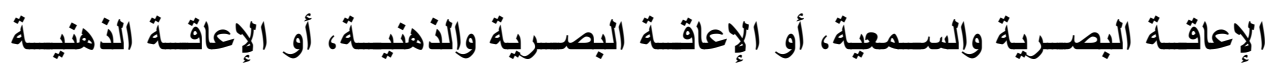
والسمعية). تشكل لجنة من طبيب التأمين الصحي، وممثل للجنـة الامج بالمديريـة، أخصائي نفسي يتم تدريبه تريويا وفقا لخطة سنوية من خلال الوزارة، وأخصائي اجتماعي، ومعلم تربية خاصـة؛ تتولى التقيـيم الطبـي والتفسي والتريسوي خـلال العام الدراسـي على كلى كل الأطفـال

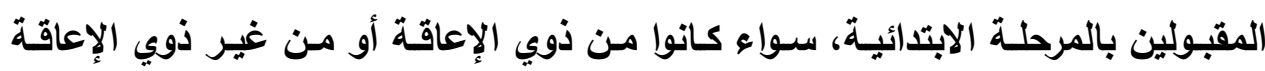

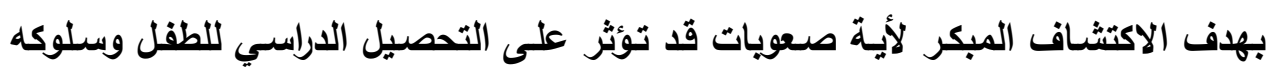
التكيفي، وتحديد المعينات الطبية والتريوية اللازمة. لا يجوز أن تزيد نسبة الأطفال ذوي الإعاقة البسيطة المدمجين على · 1 \% من إجمالي

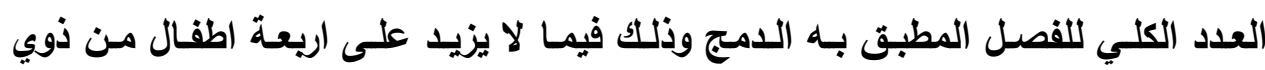
الإعاقة للقصل الواحد. يجـوز تحويـل الأطفـال ذوي الإعاقـة البسـيطة الذذين ينطبق عليهه شـروط الـمـج مـن

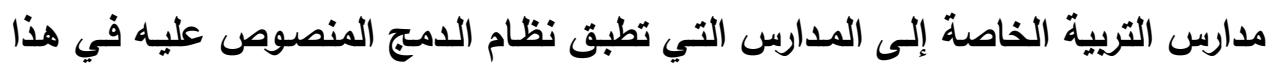
القرار من قبول الطقل بمدارس التربية يتم تدريس ذات المقررات الدراسية المخصصة لمدارس التعليم العام بمدارس الدمج، مـع

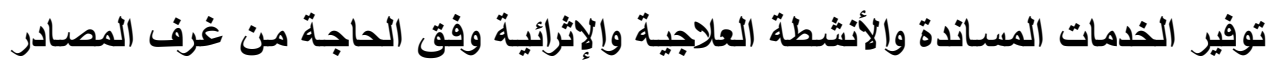
وغيرها داخل الإطار المدرسي التيسير تقليم تلك المقررات الدراسية، ويما يلبي احتياجات وفئه

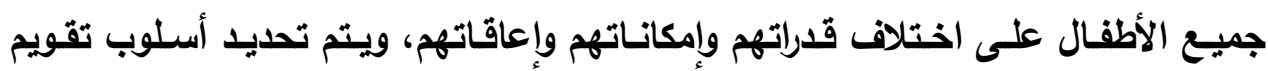

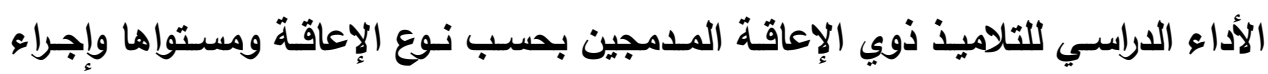

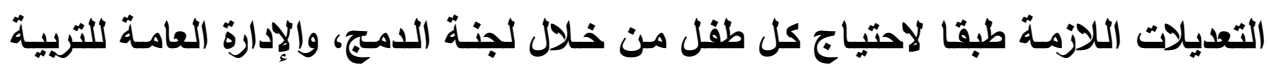
الخاصة، ومستشار التربية الخاصة بالوزارة، كما يتم تقييم أداء ذوي الاحتياجات الخاصة منة

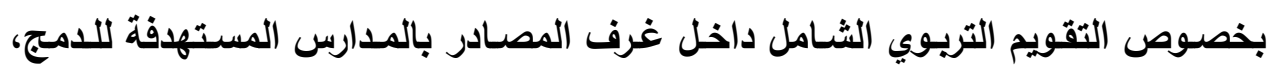
وفقا لإعاقة أي من التلاميذ المدمجين من خـلال كل من الأخصائي النفسي والأخصائي الاجتماعي ومطم التربية الخاصة ومعلمي الامبج. 
- يتم الاستعانة بمرافق تربوي أو مرافق للكتابة أثناء الدراسـة أو تأدية الامتحانـات، وذلك الكاف

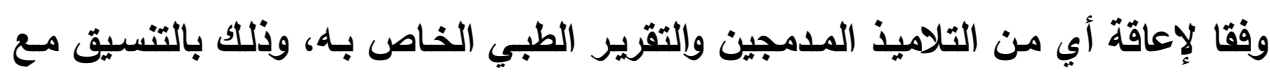

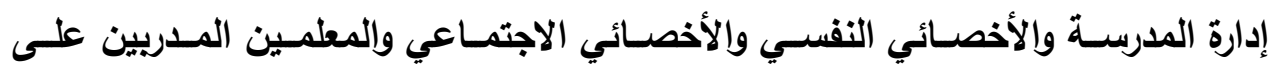
التعامل مـع ذوي الإعاقة داخل المدرسـة، ومـن خـلال التتسيق مـع الادارة العامـة للتربيـة الإية الخاصة، ومستشار التربية الخاصة بالوزارة والادارة العامة للامتحانات.

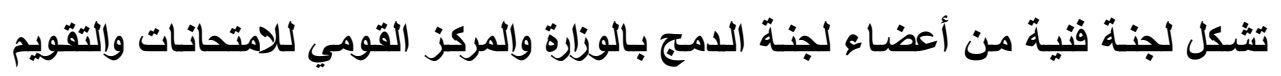
التريوي، وذلك لإعداد أورلق امتحان موضوعية ومتكافئة ومعادلة لجميع المواد التعليمية

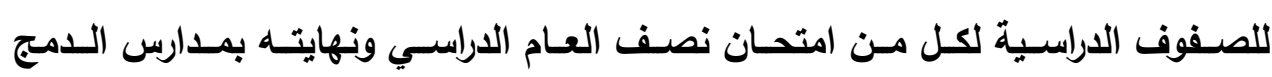
المستهدفة؛ لاختبار ذوي الاحتياجات الخاصة وفقا لإعاقة أي منهم. يتم صرف حافز إثابة للامج بنسبة ٪ • r من الراتب لمديري المدارس الدامجة والمعلمين والأخصائيين النفسيين والاجتماعيين بالفصول الدامجة التي يوجد بها تلاميذ ذوي إعاقة إنة

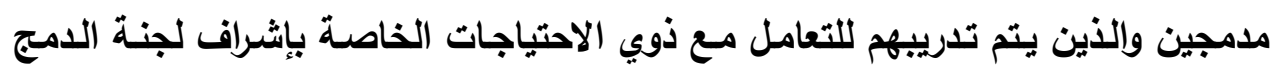

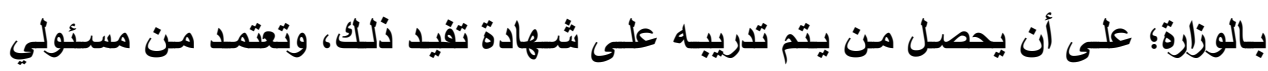
الوزارة وذلك لصرف هذا الحافز. تشكل لجنة منبثقة عن اللجنة العلميـة لمعايير قبول ذوي الاحتياجـات الخاصـة، ولجنة

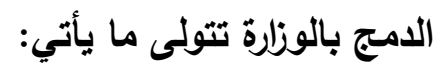
لحديد مدارس الدمج بجميع المديريات التعليمية في ممارسـات عملية الدمج داخل المدرسة.

لشر ثقافة توعوية بأهمية الدمج وجدواه لجميع أعضاء البيئة المدرسية والأسرية للأطفال المعاقين وغير المعاقين في مدارس الدمج وكذلك تثفيذ حمـلات التوعية الثقافية بخصوص الدمج للمجتمع المحلي ولأسر المعاقين وغير المعاقين.

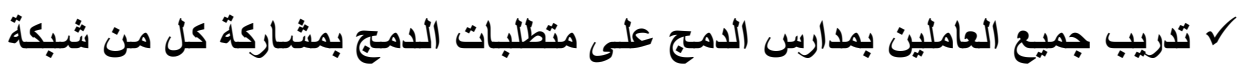

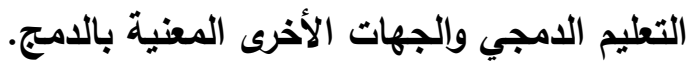

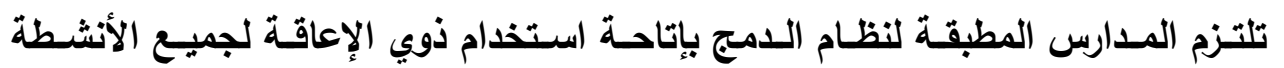
والخدمات الاجتماعية والصحية والنفسية المقدمة من المدرسة وفي ذات الأماكن المتاحة للأطفال غير المعاقين، ويجب أن تكـون هذه الخدمات متاحـة فيزيقية لذوي الإعاقة 
ومعدة لتقديم خدماتها لهم بالطرق والأسـاليب المناسبة لنوع ودرجة الإعاقة بما ينمي

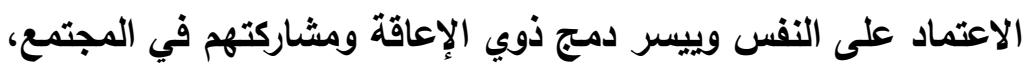

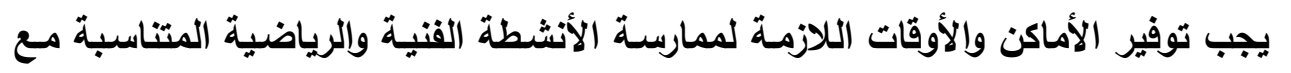
ظروف الطفل ذو الإعاقة من الناحية الاجتماعية والبيئية والصحية والإتاحة الفيزيقية للأبنية (أي أن تكون البيئة المدرسية مرحبة ومتناسبة مـع جميع الاعاقات المستهدفة

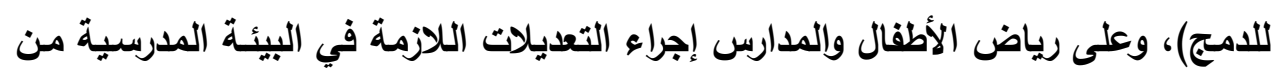
ناحية الوسائل التعليمية وطرق التدريس ووسائل التقييم وغير ذلتك من الإجراءات التي تيسر الدمج على ألا يشكل التعديل اللازم عائقا لعملية دمج ذوي ولئي الإعاقة.

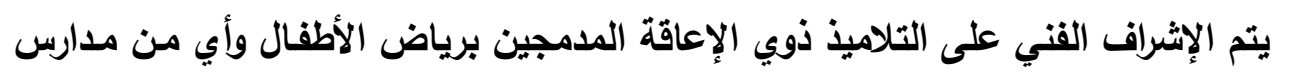

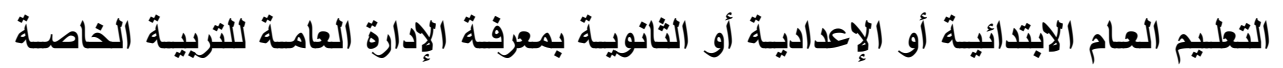

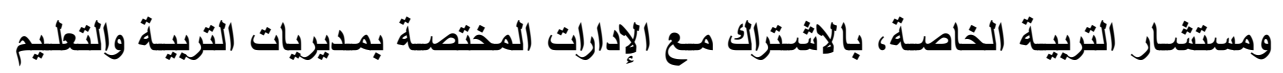

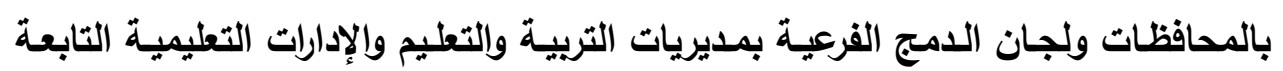
لها. • يطبق في شأن التلاميذ ذوي الإعاقة المدمجين بالمدارس التي تطبق نظام الدمج - في

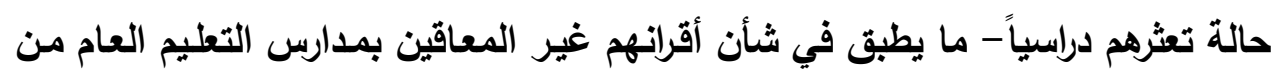
لوائح وقرارات.

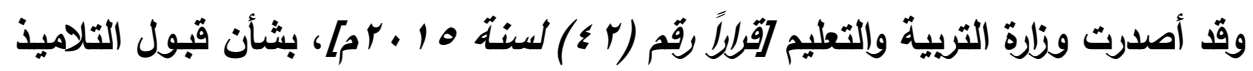
ذوي الإعاقة البسيطة بمدارس التعليم العام. وتضمن القرار أن يتم قبول الطفل ذي الإعاقة

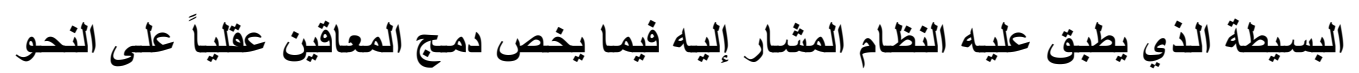

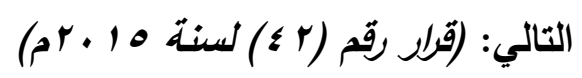

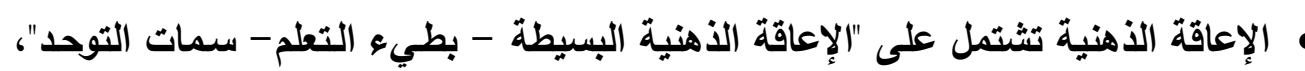

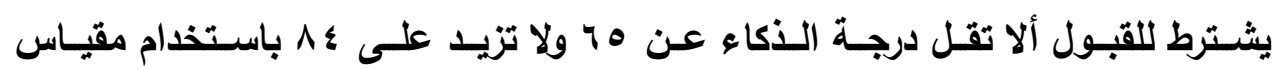

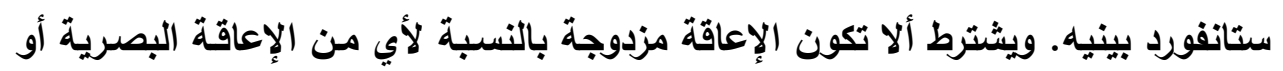
السمعية أو الذهنية. • أن "تثكل لجنـة من طبيب التأمين الصحي، وممثل لجنـة الـمبج بالمديريـة، وإخصـائي

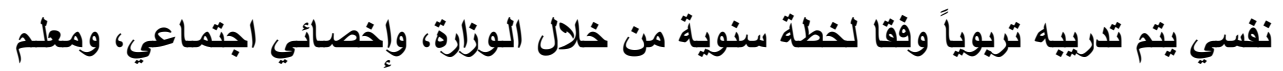


تربية خاصـة، وتتولى هذه اللجنة التقييم الطبي والتفسي والتربوي خـلال العام الدراسي

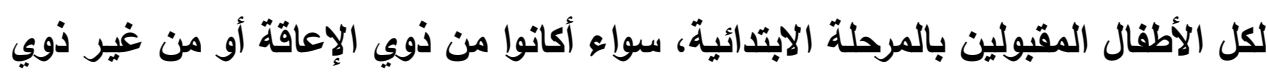

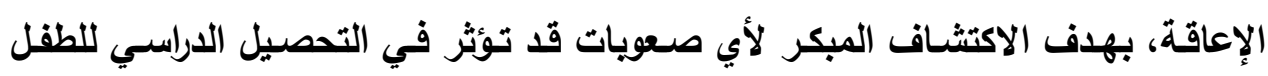
وسلوكه التكيفي، وتحديد المعينات الطبية والتريوية اللازمة".

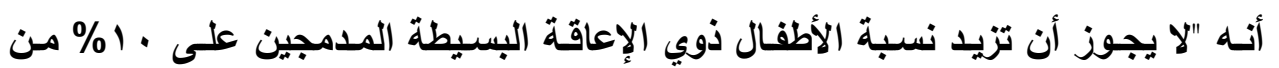

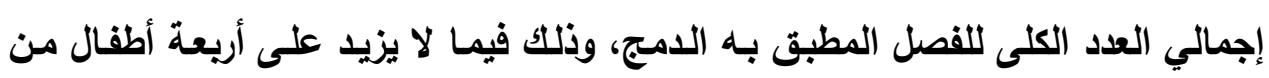
ذوي الإعاقة للفصل الواحد". هيتم تدريس ذات المقررات الدراسية المخصصة لمدارس التعليم العام بمدارس الدمج، مـع

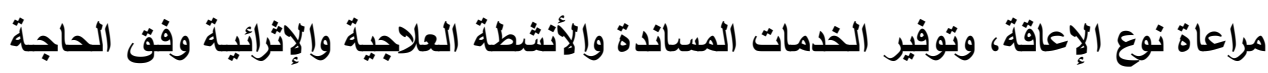

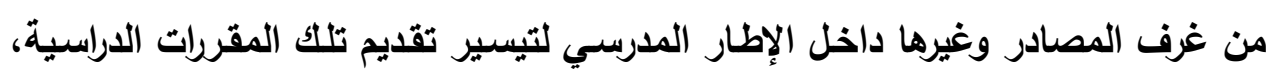

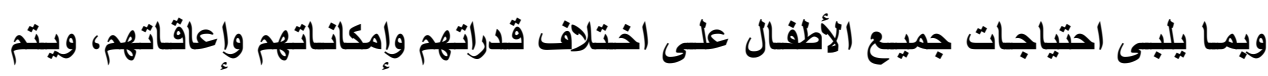

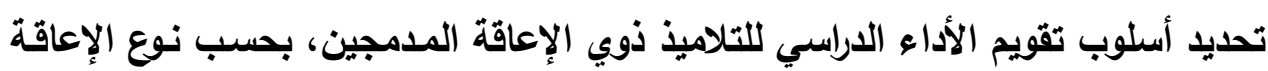
ومستواها وفقا لمواصفات الورقة الامتحانية للتلاميذ المدمجين.

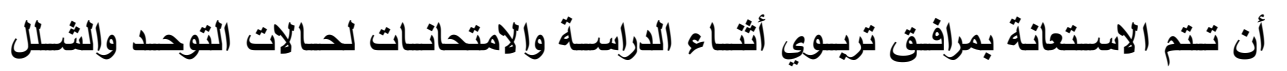

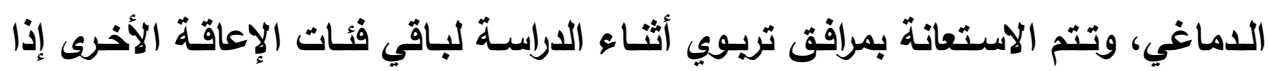
اقتضث الضرورة لذلك. يتم التقام للالتحاق بمدارس الدمج أو للامتحانـات الموضوعية من بداية العام الدراسي حتى · r نوفمبر من نفس العام الدراسي، وليس لأحد الحق في التقدم بعد هذا الميعاد،

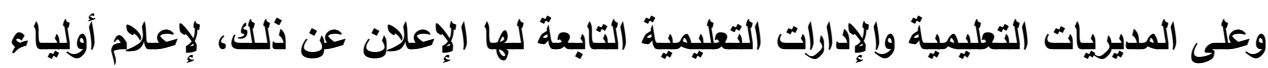

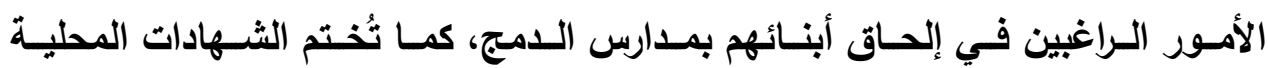
(الابتدائية- الإعدادية) والثـهادات العامـة (الثانويـة العامـة) بختم طالب دمـج مـع تحديد نوع الإعاقة.

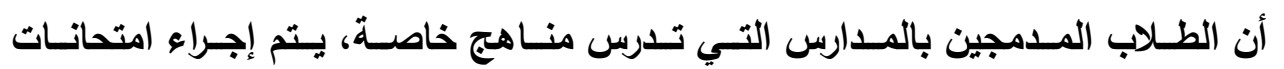

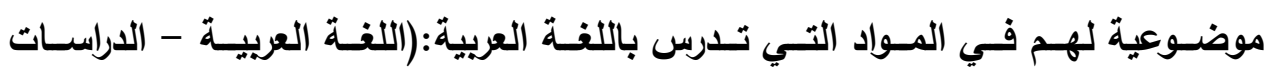

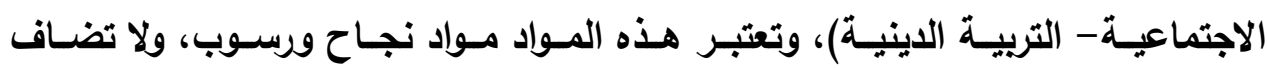
للمجموع. 
• يُعفى الطلاب ذوو الإعاقة البسيطة (الإعاقة الذهنية البسيطة - متلازمـة داون - الشلل

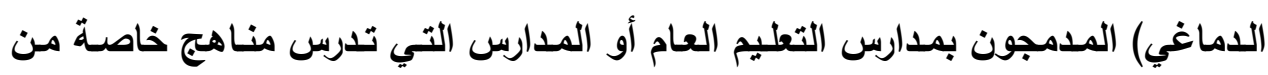

دراسة اللغة الأجنبية الثانية.

يـؤدي الطـلاب المـدمجون بمدارس التعليم العـام امتحـان الإمـلاء والخط في مـادة اللغـة

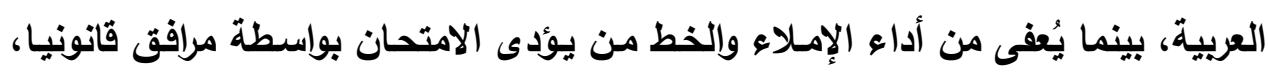
وتوزع درجاتهما على باقي أجزاء الإجابة.

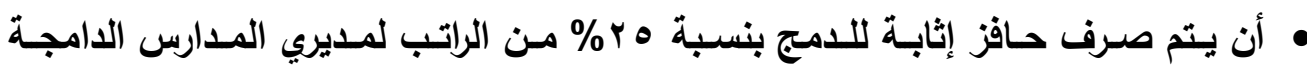

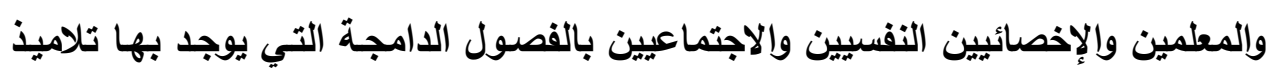

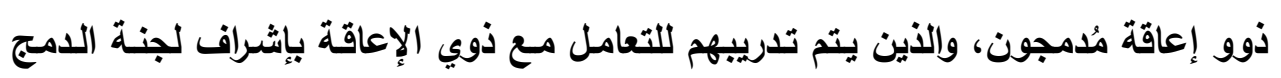

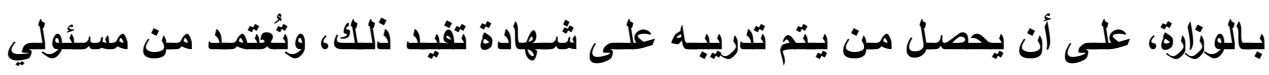

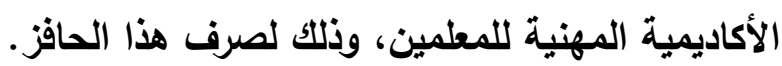

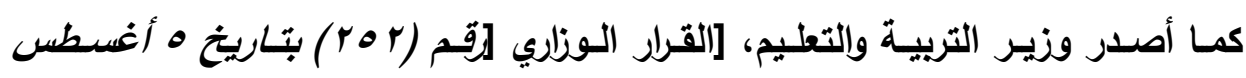

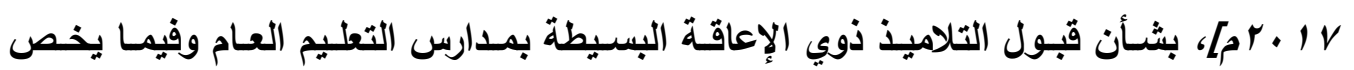

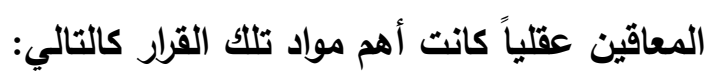
• يطبق نظام الدمج للطلاب ذوي الاعاقة البسيطة بالفصول النظامية بمدارس التعليم العام

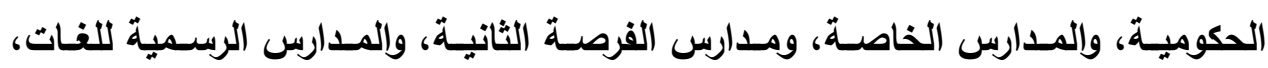

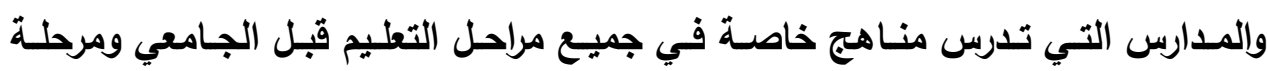

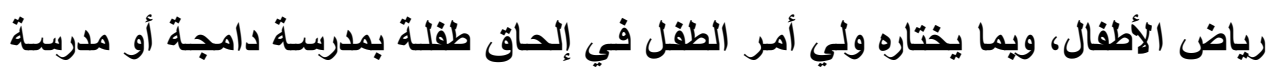

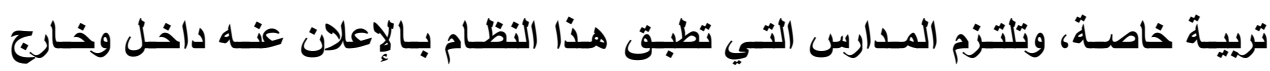
المدرسة. • أن كل المـارس دامجـة بمـا فيها مـدارس (التعليم المجتمعي)، ومـن حق الطالب ذي

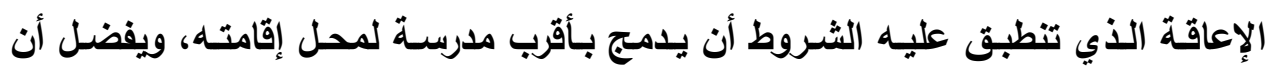

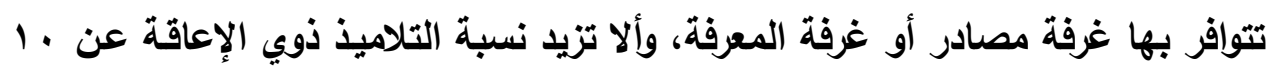
\% من العدد الكلي للفصل بحد أقصى ؛ تلاميذ، على أن يكونوا من نفس نوع الإعاقة.

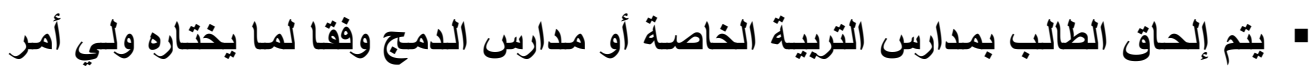
الطالب ذي الإعاقة. 
- ضرورة أن يبلغ سن الالتحاق بالصف الأول الابتدائي بمدارس الدمج هو من 7 إلى 9

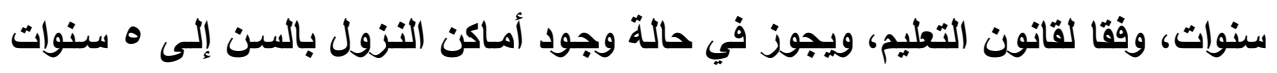
ونصف مع عدم الإخلال بالكثافة المقرةة.

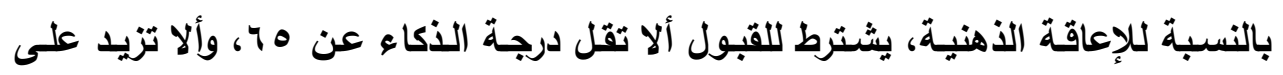

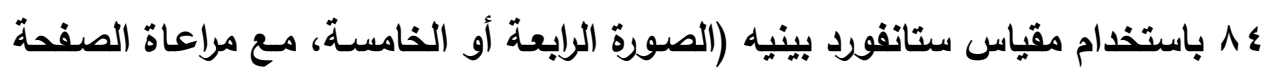
النفية، ويما يتوافق مع نتائج مقياس السلوك التكيفي المناسب للامج الكلي. تتضمن الاعاقة الذهنية جميع المتلازمـات التي تتدرج تحت الاعاقة الذهنيـة البسيطة،

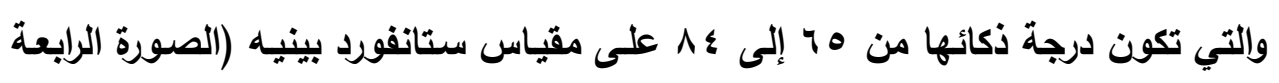
والخامسة) الاعاقة الذهنية البسيطة. أما بطيئو التعلم فهم التلاميذ الذين يكون التحصيل

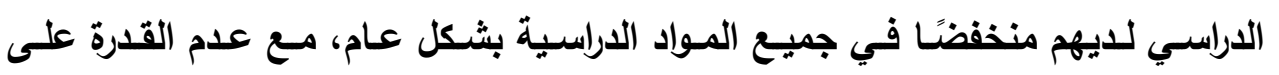

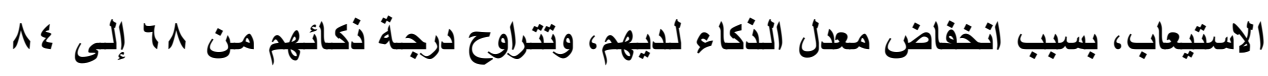

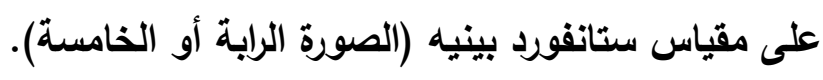
يتم قبول التلاميذ متعددي الإعاقة بمدارس الدمج ويستثنى من ذلك الاعاقة الحركيـة

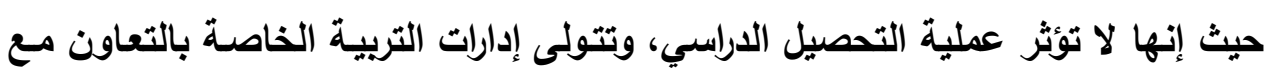
الإدارات العامة المعنية التالية (التعليم المجتمعي - رياض الأطفال - المدارس الرسمية

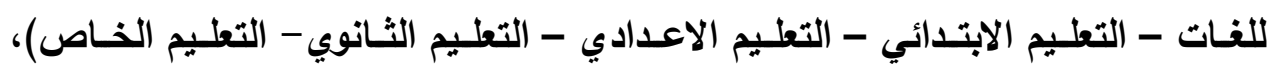
والمؤسسـات المرتبطة مـع الوزارة باتفاقيـات تعـاون مشترك أو موافقـات أمنيـة صـريحة

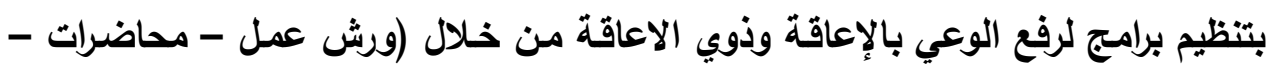
لقاعات). • يتم تفعيل وحدة التدريب بالمدرسة لخدمة نظام الامج او تنظيم تدريبات للمعلمين، بشرط

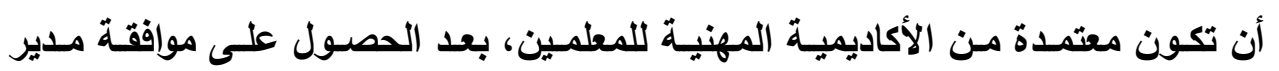

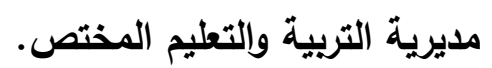

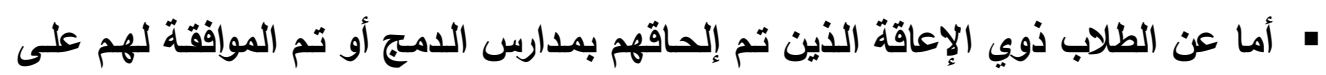

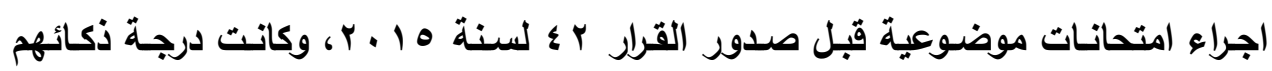

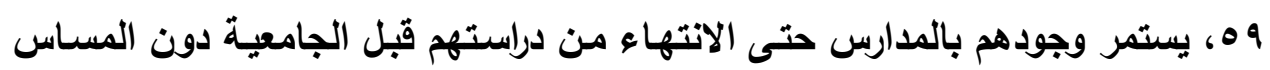
بحقوقهم التي اكتسبوها من قبل. 


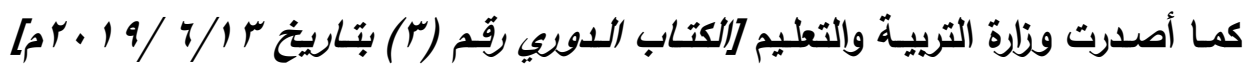

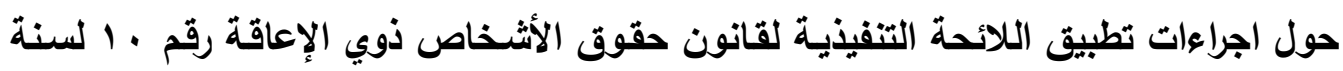

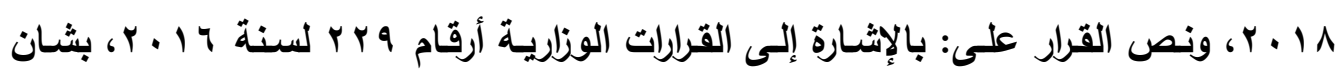

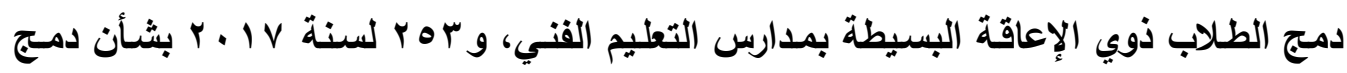

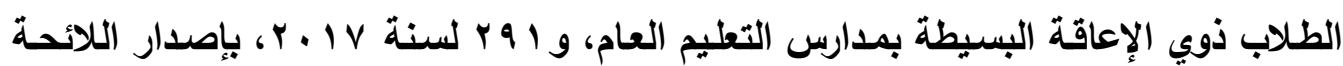

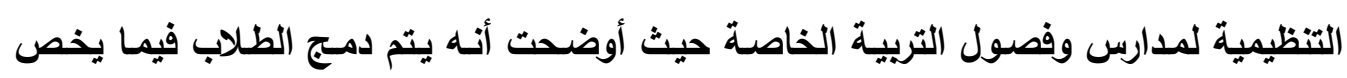
ذوي الإعاقة العقلية بمدارس التعليم العام والتعليم القني بالشروط الأتية:

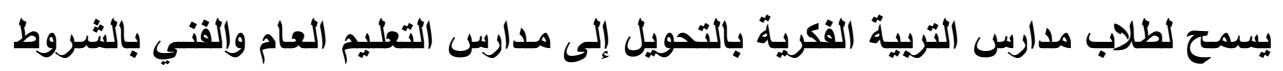
الآتية: لا ألا يتجـاوز سـن الطالب عنـــ التحويـل (9) تسـع سـنـوات للالتحــاق بالصـف الأول الابتدائي ل أن يكون مقياس الذكاء مناسبا للقبول وفق الاثتراطات الخاصـة بالدمج في التعليم

\section{العام}

ل أن يكون الطالب قد درس المناهج المعدلة

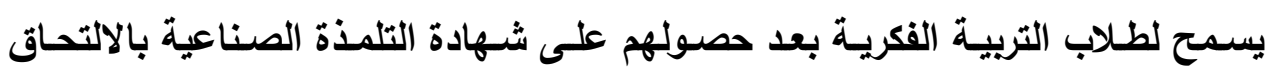

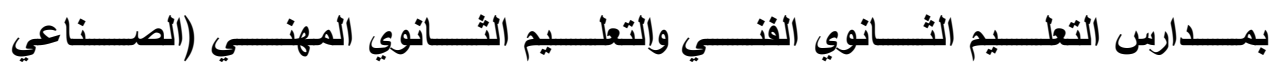

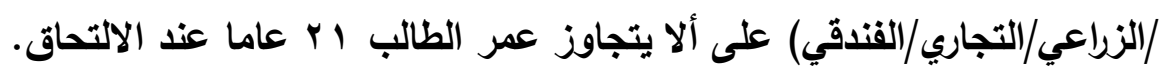

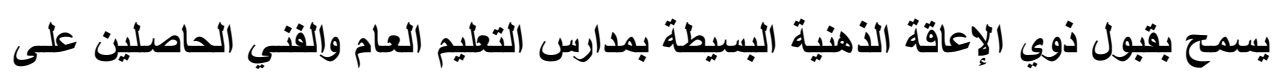

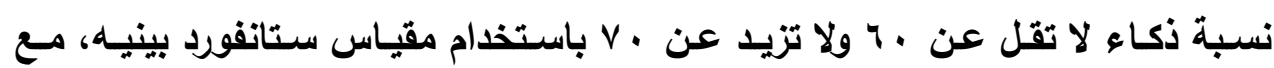
مقياس السلوك التكيفي على ألا تزيد درجة القصور عن مجالين، وذلك اعتبارا من العام

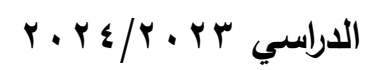
يسمح بقبول ذوي الإعاقة الذهنية البسيطة بمدارس التعليم العام والقني الحاصلين على هلى نسبة ذكاء لا تقل عن به ولا تزيد عن • باستخدام مقياس ستانفورد بينيه، على ألا

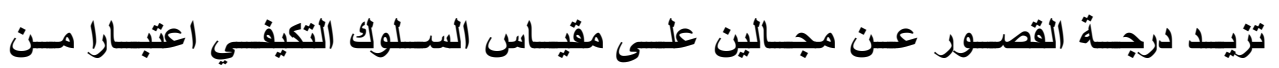
$r \cdot r V / r \cdot r q$ 


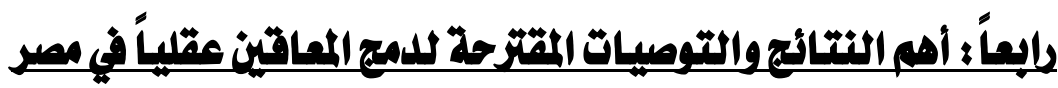

يتضح مما سبق عرضه من الإطار النظري أو ما تم عرضه من قرارات وزاريـة تتعلق

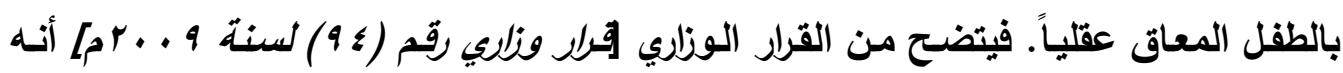

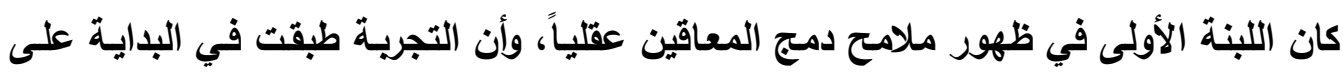

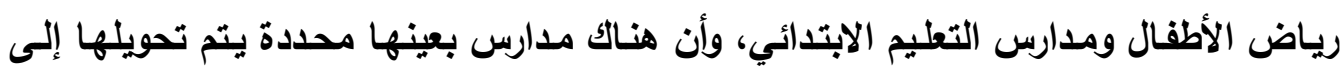

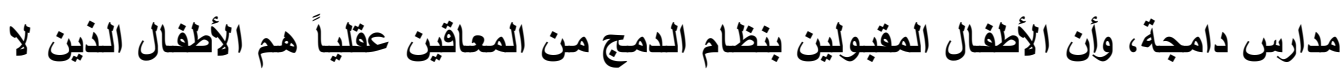

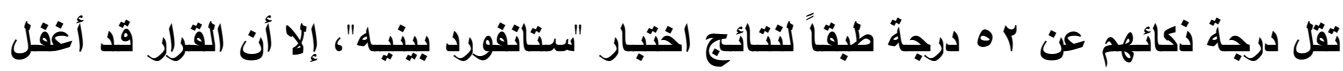

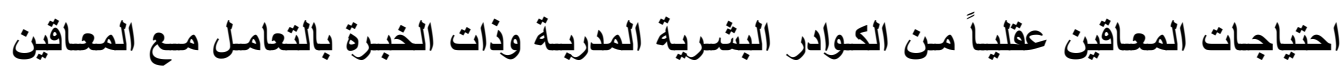

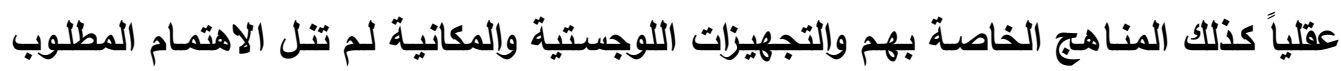
وأكتفى القزار بالإثـارة البسيطة كأن موضوع التقويم والامتحانات تتولاه إدارة التربية الخاصة

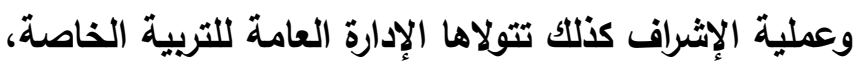

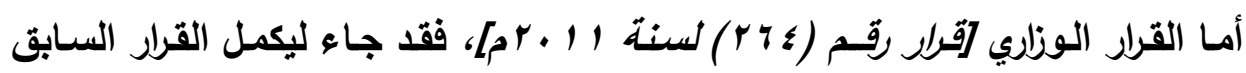

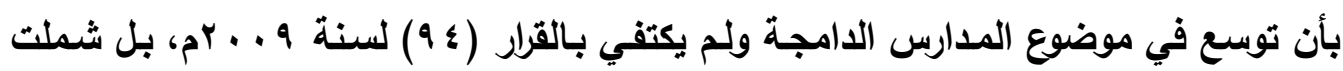
المدارس الدامجة كافة مراحل التعليم قبل الجامعي ولم تقتصر على مرحلة رياض الأطفال

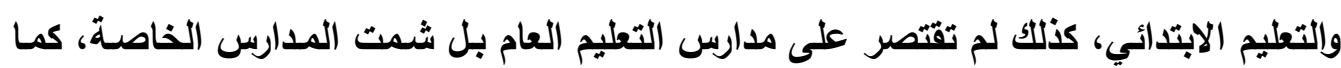

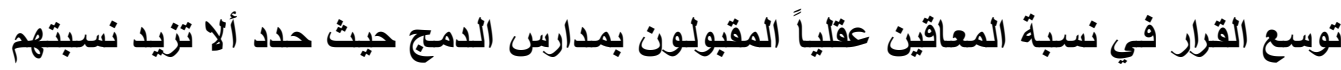
عن (• 1\%) في الفصل الواحد، وفي هذا القرار تم فرض مناهج التطليم العام على المعاقين

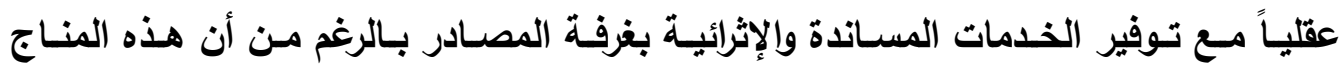
المخصصة للعاديين بمدارس التعليم العام غير مناسبة لقدرات ومستوى الأطفال المعاقين

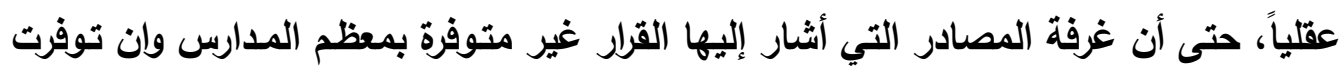

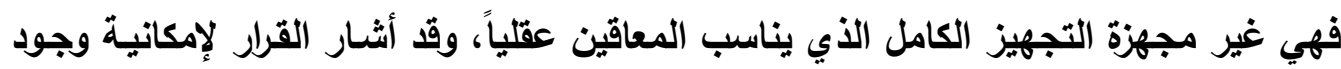

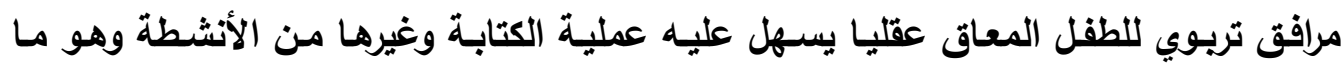

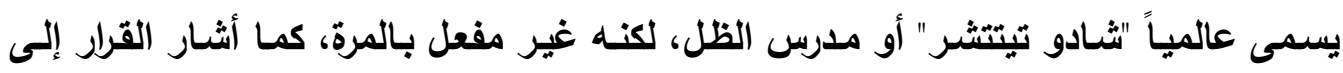

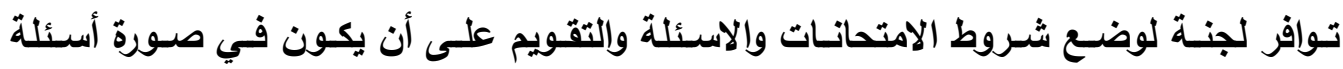
موضوعية، وهو ما تم بالفعل لكن من حيث الثكل فقط دون مراعاة المضمون ومستوى هذه الاهن الاسئلة من حيث الصعوية والمنهج الغير ملائم بالمرة للمستوى العقلي للطفل المعاق عقليا 
الذي لا يزيد مستواه العقلي عن (rه درجة) ذكاء. أشـار القرار إلى العديد من لجان الدمج

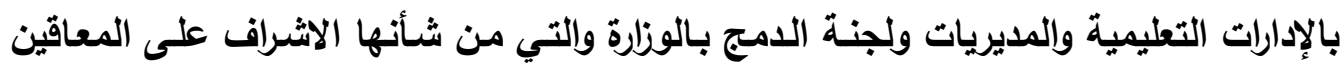

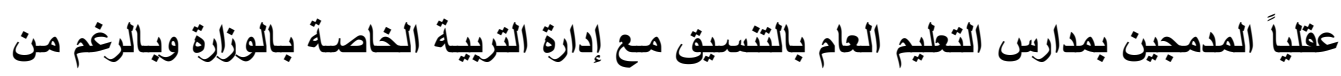

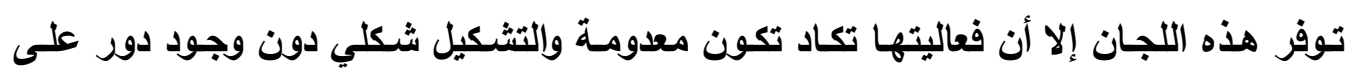
الأرض باستثناء المراسلات الخاصة بمواصفات الورقة الامتحانية.

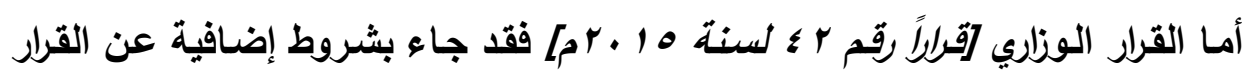

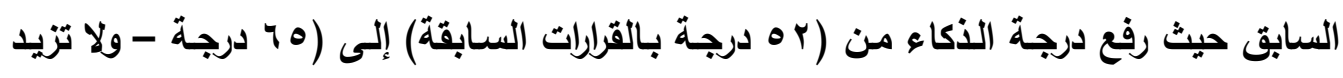

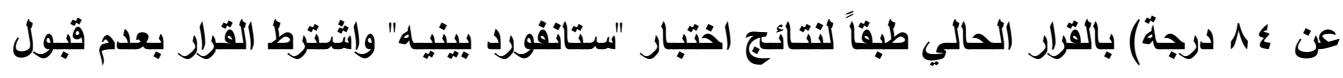

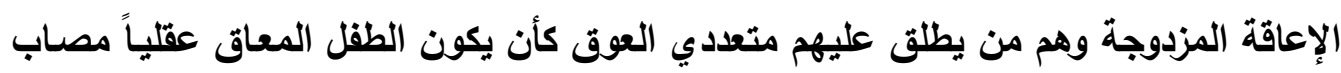

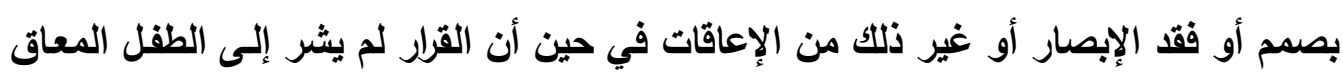

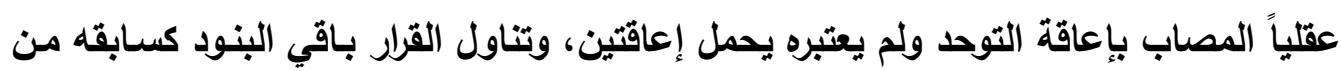

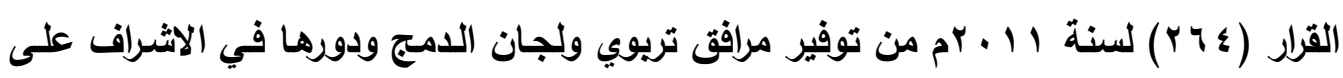

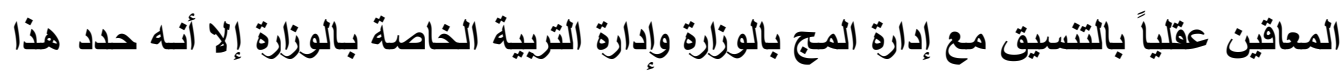

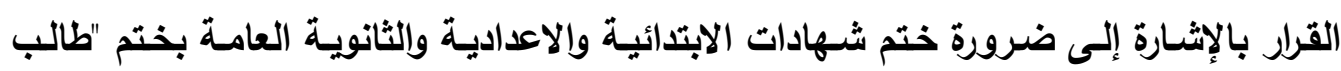

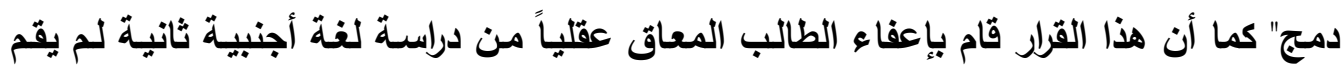

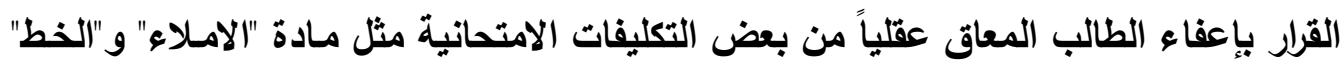
الا إذا توفر مرافق قانوني وتريسي فيتم الإعفاء وتوزع الدرجة على باقي الاسئلة وهذا يتنافى

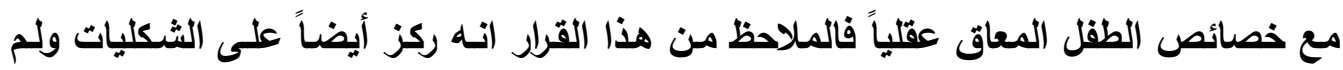
يراع توفير الاحتياجات البشرية واللوجستية اللازمة لتعليم ذوي الاحتياجات الخاصة.

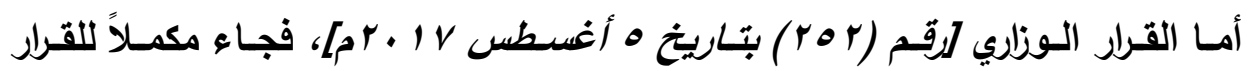

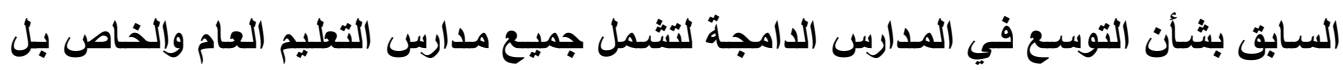
توسع إلى مدارس الفصل الواحد "التعليم المجتمع" وأعتبر أن كل المدارس دامجة ملة، ركز القرار

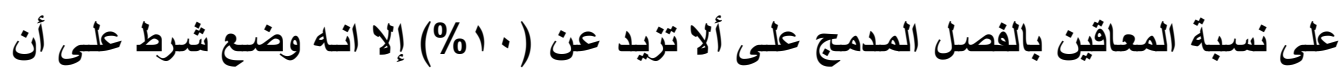

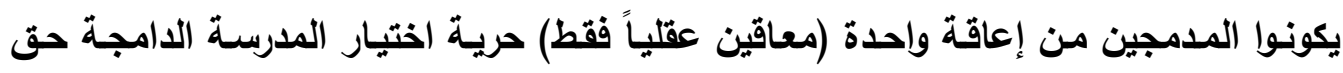

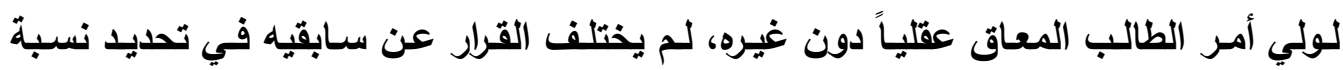

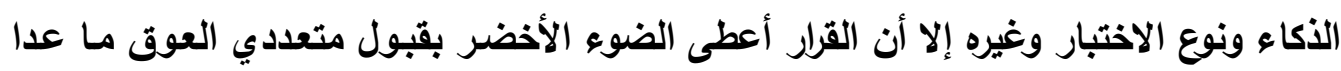


المعاقين إعاقة حركية، كما أوصى القرار في سابقة من نوعها بضرورة عمل اتفاقيات تعاون

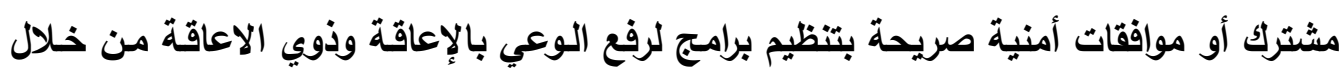

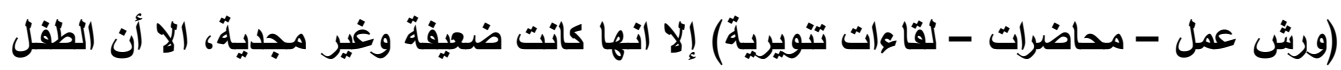
المعاق عقلياً لا زال يعاني من تدني الخدمات البشرية واللوجستية ويفتقد الاهتمام الامثل بـه الآه ويتربيته بالمدارس التي تطبق نظام الدمج.

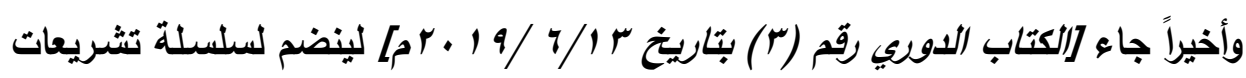

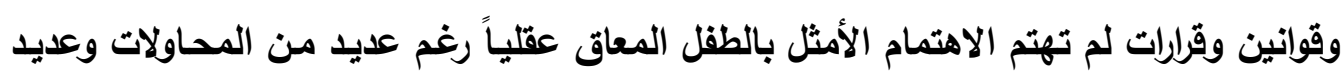

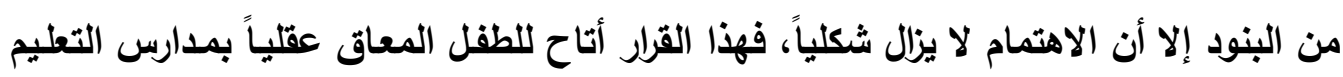

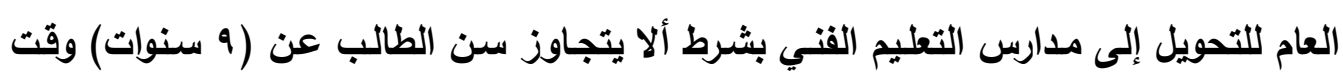

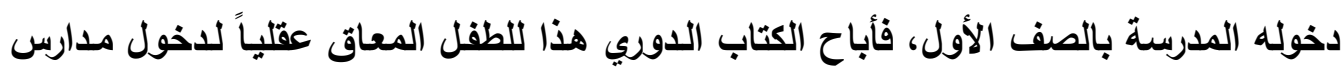

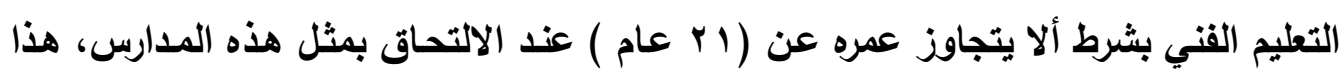

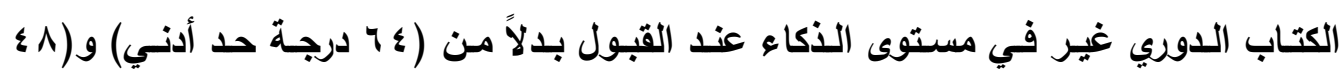
درجة) حد أقصى وأصبحت نسبة الذكاء المسموح بها بموجب هذا الكتاب الدوري ( • ج درجة)

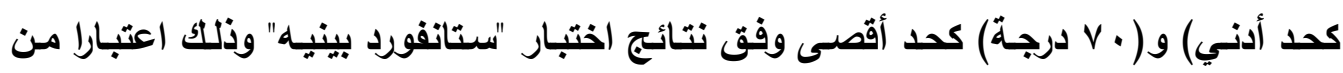

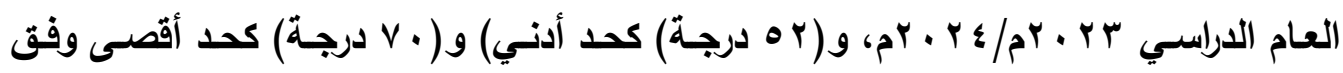

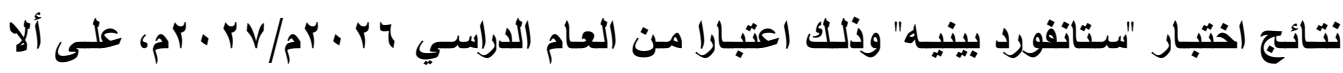
تزيل درجة القصور عن مجالين على مقياس السلوك التكيفي. ومما سبق عرضة من قرارات وزارية متعقة بدمج المعاقين عقلياً، يمكن استتباط وتحديد

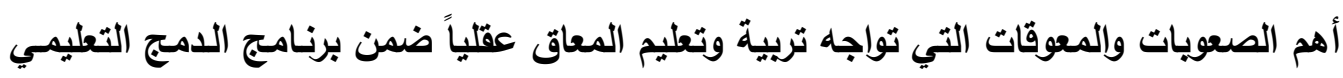
له في إطار سياسة الدمج الثامل التي تتتهجها وزارة التربية والتعليم كالاتي:

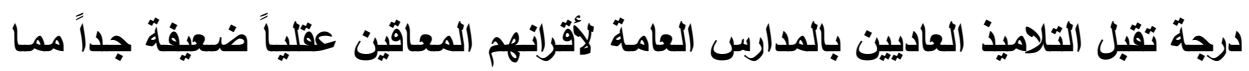
قد يؤثر على الأهداف المرجوة من الدمج.

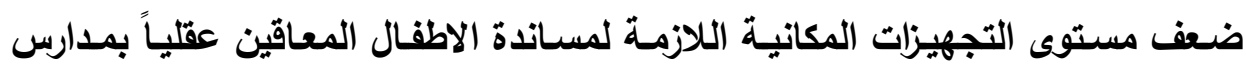
التعليم العام. المناهج الخاصة بطلاب التعليم العام من العاديين غير مناسبة للمعاقين عقلياً. 
نظام التقويم والامتحانات المطبق على الطلاب العاديين هو ذاته المطبق على المعاقين عقلياً مع تعديل في نوع الأسئلة وإعتماد الأسئلة الموضوعية فقط مـع الطلاب المعاقين عقلياً دون مراعات المستوى العقلي لهؤلاء الطلاب. عدم توافر العناصر البشرية المدرية للتعامل مع الطلاب المدمجين من المعاقين عقلياً.

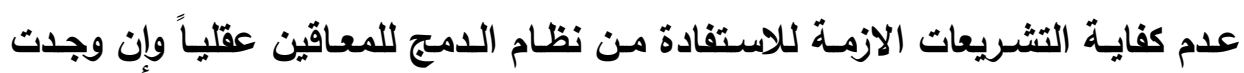
التشريعات فهي غير شاملة لكل جوانب نظام الامج الشامل. وجود مشكلات لاى الطقل المعاق عقلياً تتمثل في الشعور بالعزلة والوحدة بين الطلاب الطي العاديين وعدم تكيفهم بالمدارس المطبق بها نظام الامج.

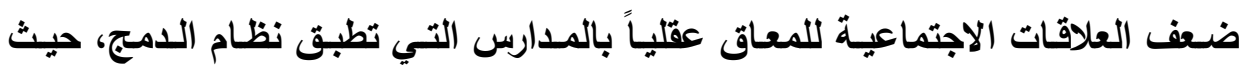

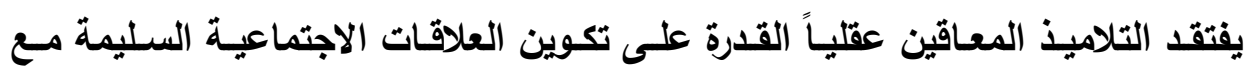
أقرانهم العاديين بالمدارس الدامجة. شعور التلاميذ المعاقين عقلياً في بعض الأحيان بالدونية بالنسبة العاديين، وقد يرجع

ذلك لضعف التهيئة لاي الطلاب العاديين لاستقبال زملائهم الطلاب المعاقين عقلياً. ( • (1) لجان وإدارات الدمج على مستوى محافظات الجمهوريـة متصلة بلجنة الدمج الرئيسية بالوزارة والتي مهمتها تنفيذ ومتابعة عمليات الامج بالمحافظات غير معدة وغير مجهزة التجهيز اللائم وغنما موظف ومكتب بـالإدارة التعليميـة أو المديريـة والفعالية وإلكفاءة في الاداء ضعيفة جداً. (1) حصول بعض أولياء الأمور على شهادات طبية بمستوى ذكاء أطفالهم وهذه الشهادات غير سليمة ومكذويـة والهـدف منها استفادة ابنهم ببعض مزايـا الطفل المعاق عقلياً

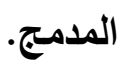
(r r ا ) شعور المعاقين عقلياً بالخجل في معظم الأحيان في القيام بالأنشطة المدرسية أمسام زملائهم، وشعورهم بعدم الانتماء إلى المدارس العادية،

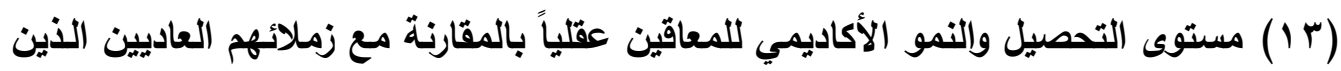
يدرسون نفس المقررات الدراسية غير مرضي.

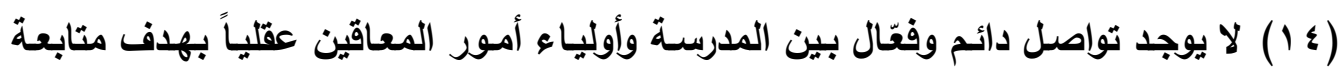
وضع الطالب بشكل جيا. 
(0 1 ) ضـف مشـاركة أولياء الأمسور في القرارات المتعلقة باتخـاذ القرارات المتعلقة بـالبرامج

التعليمية للمعاقين عقلياً.

(7 ا ) ضعف الوعي المجتمعي بأهمية عمليات الامج للمعاقين عقلياً.

ويمكن عرض التوصبات المقترحة لامج المعاقين عقلباً بمدارس التعلبم العام كما بلي:

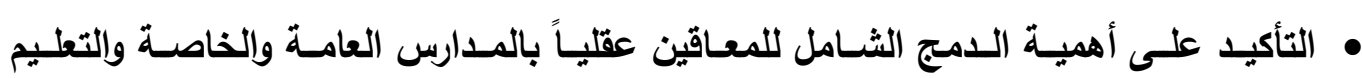
المجتمعي بشتى المراحل الدراسية.

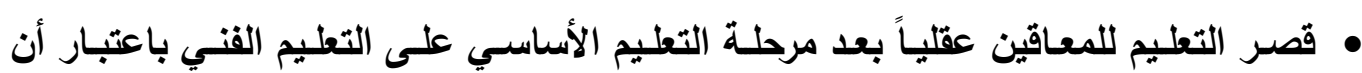
قدراتهم العقلية محدودة ولا تمكنهم من مواصلة التعليم الثانوي العام والجامعات. • رفع مستوى الكفاءة بمدارس التعليم الفني وتهيئتها لاستقبال الطلاب المدمجين المعاقين مواصلين عقلياً.

• التأكيا على أهمية نظام الدمج إعلامياً وعبر منصات التواصل الاجتماعي بشكل دوري عبر

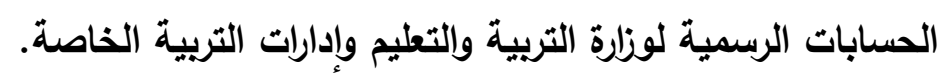

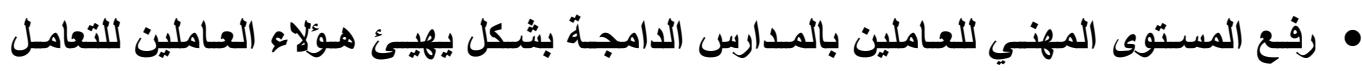
الصيح مع المعاقين عقليا المدمجين بمدارس التعليم العام.

• تطويع المناهج الدراسية وتبسيطها بشكل يتناسب مع مستوى تحصيل المعاقين عقلياً.

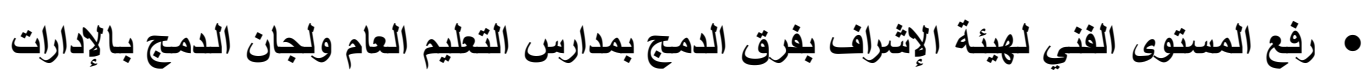

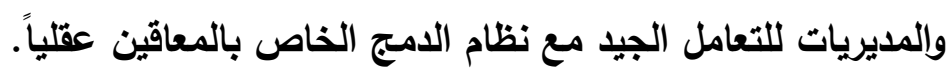

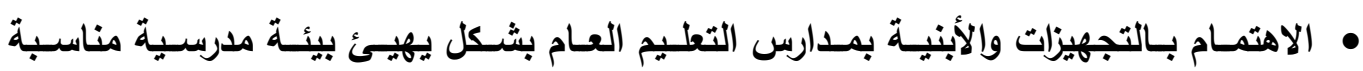
للمعاقين عقلياً.

• الاهتمام بالأنثطة الصفية واللاصفية للمعاقين عقلياً بمدارس التعليم العام الامجة. • مشاركة أولياء أمور الطلبة ذوي الإعاقة في عملية الدمج واتخاذ القرارات المتعلقة بأبنائهم

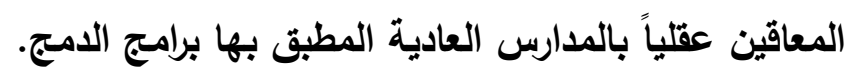

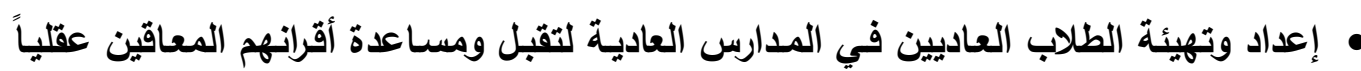
المدمجين معهم وتكوين اتجاهات ايجابية نحوهم.

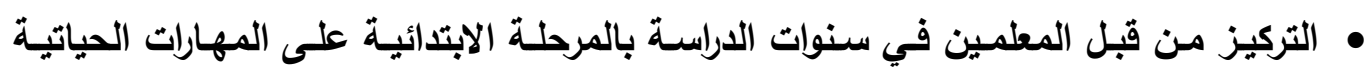

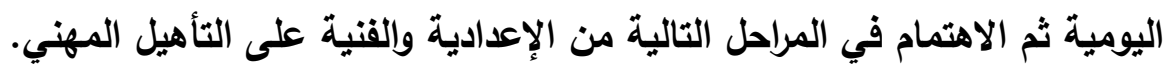


• تفعيـل السياسـات والتشـريعات المحليـة التـي توضـح وتـنظم عمليـة الـدمج للمعـاقين عقليـاً بمدارس التعليم العام، ومواكبـة سياسـة الدمج للمستجدات الدديثة بمـا يتلاعم وإحتياجـات المعاقين عقلياً بالمجتمع المصري. • تفعيل دور اللجان الخاصة بالدمج بالإدارات والمديريات التعليمية والمسئولة عن استمرارية

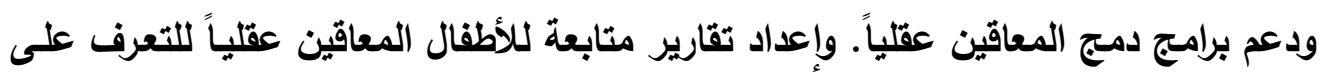
مدى التقدم الايجابي من سياسة الدمج المتبعة. • توفير كافة الخدمات الصحية، والتفسية، والاجتماعية المادية والبشرية المسـاتدة التي تمكن التهن

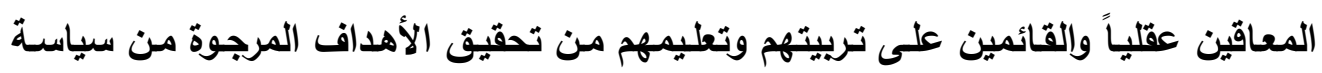
دمجهم. • توفير المعلمين المساعدين القادرين على تقديم العون والخدمات المساندة لمعلمي المعاقين عقلياً بمدارس الامج أو ما يعرف بـ (مدرس الظل) وذلك لتسـهيل المهمة التريويـة والتعليمية للمعلم الأساسي.

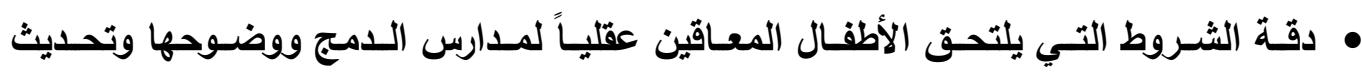
المقاييس المتبعة لقباس نسب الذكاء وتدريب الأخصائيين على المقاييس الحديثة وذلك

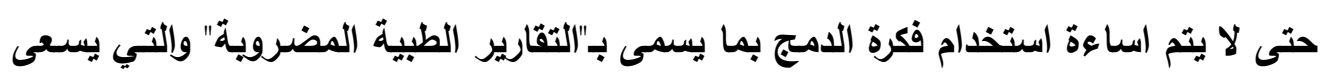
اليها احياناً أولياء الأمور للحصول على مستوى أقل لأسئلة الامتحانات.

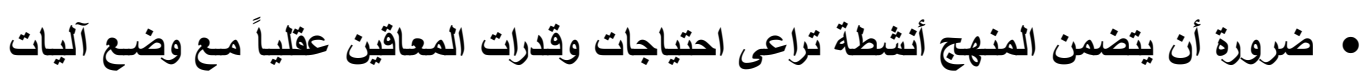

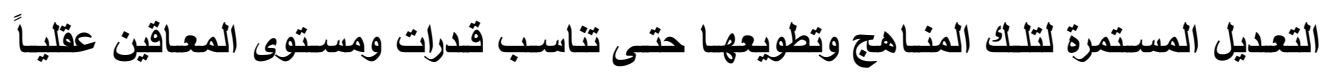
المدمجين بمدارس التعليم العام.

التوصياتة

• تفعيل الدور الإعلامي في توعية أولياء الأمور بأهمية الدمج.

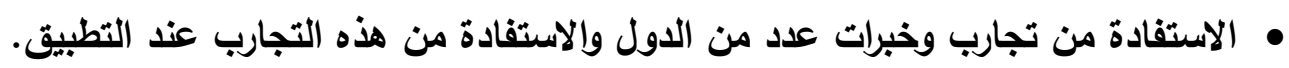

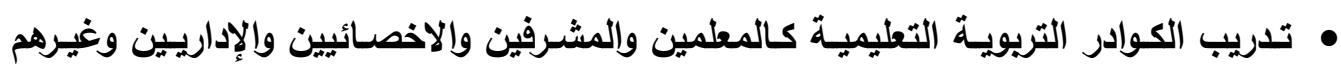
حول أهمية برامج دمج المعافين عقلياً بمدارس التعليم العام. • تأهيل أسر المعاقين عقلياً وكذلك أسر الطلاب العاديين على تقبل كل واحد منهم الأخر. 
تشـيع ابحث العلمـي نحو عمل دراسـات يكون من شـأنها رفع كفاءة نظـام الدمج في

$$
\text { مصر. }
$$

\section{خاثة:}

قدم الباحث في هذا البحث " واقـع الدمج التعليمي للمعاقين عقلياً بمدارس التعليم العام

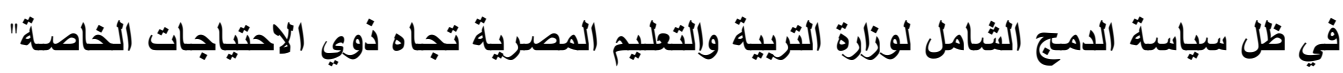

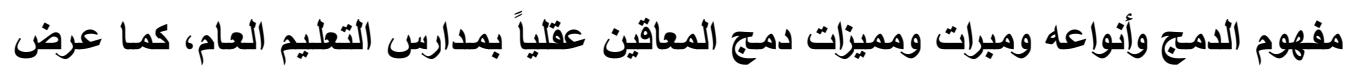
الباحث مفهوماً عن الإعاقة العقلية وأنواع الإعاقات العقلية ومستوياتها وحدد الباحث في هذه ومنه

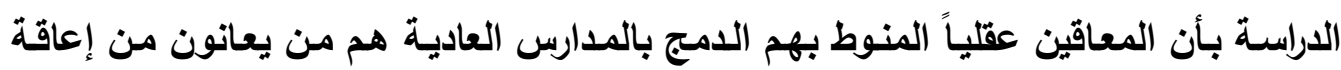

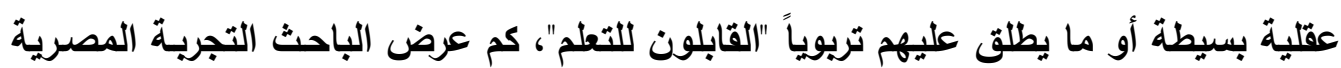
لامج المعاقين عقلياً وواقع عملية دمـج هؤلاء الاطفال من خـلال عرض لأهم قرارات الدمج

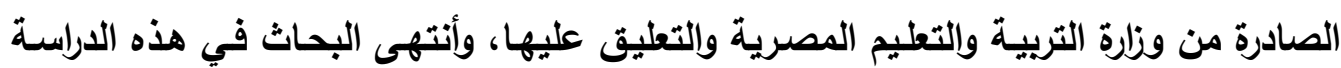
لأبرز النتائج ويعض التوصيات المقترحة ثم أهم التوصيات. 


\section{| - المراجع}

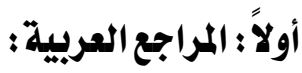

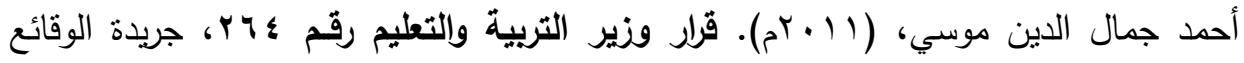

المصرية، جمهورية مصر العربية.

أحمد علي، وبدوي محمد، (ع . . rم). دمج ذوي الاحتياجات الخاصة في المدارس العادية وارتباطه ببعض المتغيرات، المؤتمر الثاني عشر بعنوان التعليم للجميع وآفاق جديدة في تعليم

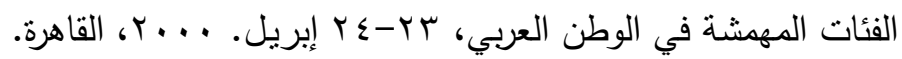
آمال مليجي، (r . .rم). سيكولوجية غير العاديين (ذوي الاحتياجات الخاصة)، القاهرة: مكتبة الأنجلو المصرية.

أميرة القرشي، (0. ․ rم). منطلبات الدمج الثشامل للأطفال المعوقين سمعياً في مدارس وفصول التعليم العام، بحث منشور، المؤتمر العلمي السنوي الثالث عشر بعنوان التربية وآفاق جديدة في مئري تعليم ورعاية ذوي الاحنياجات الخاصة المعوقين والموهوبين في الوطن العربي، كلية التربية، من النئ

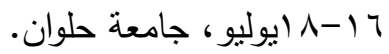
إيمان فؤاد كاشف، عبد الصبور محمد، (991 (م)). دراسة تقويمية لتجربة دمج الأطفال ذوي

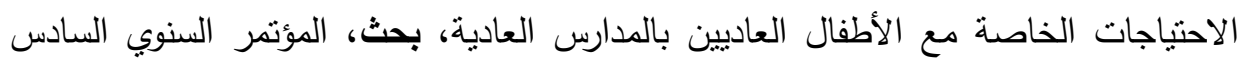
عشر ، جامعة عين شمس. الزهرة بجادي، (1) • rم). واقع دمج الأطفال ذوي الإعاقة العقلية البسيطة بالمدارس الابتدائية) الأقسام الخاصة (من وجهة نظر أخصائي المركز النفسي البيداغوجي، مذكرة مكملة لنيل شهادة الماجستير، كلية العلوم الإنسانية والاجتماعية، الجزائر .

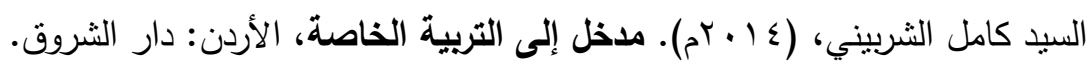

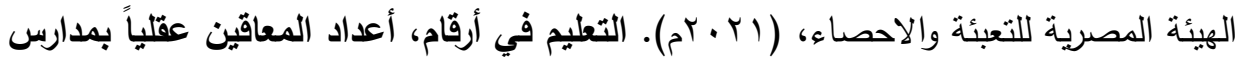

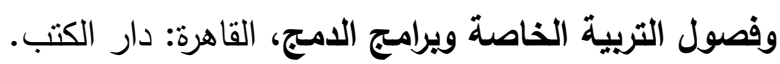

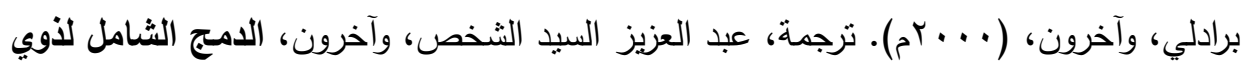

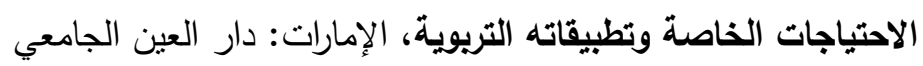

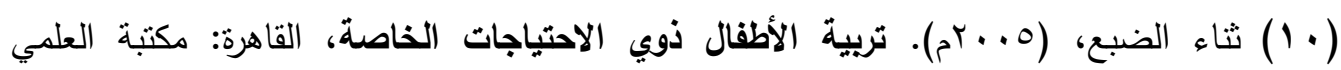

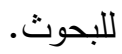


(1) جمال محمد الخطيب، (1991م). تعديل سلوك الأطفال المعاقين، دليل الآباء والمعلمين، عمان: دار إثراق للنشر والتوزيع.

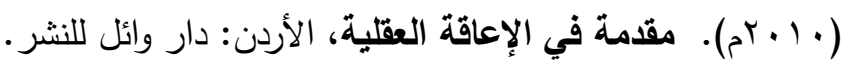

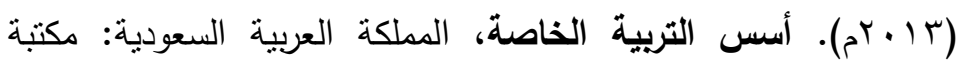

المتنبي.

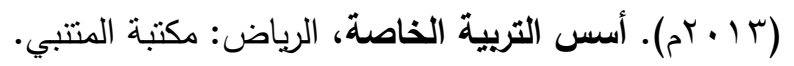

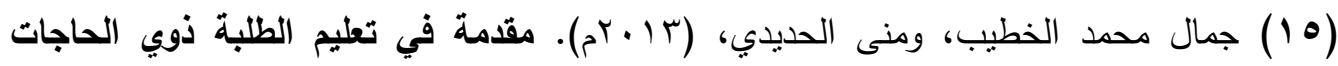
الخاصة، طج، الأردن: دار الفكر.

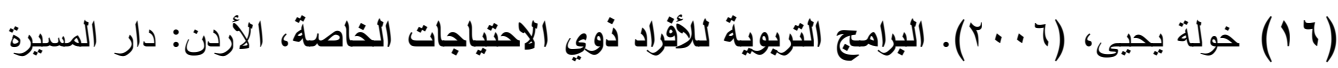
للنشر والتوزيع.

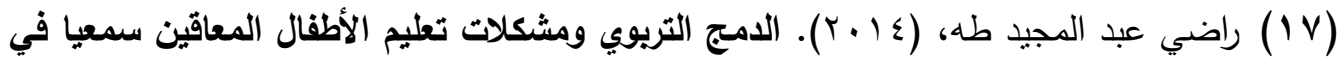
مدارس التعليم العام، القاهرة: دار الفكر العربي.

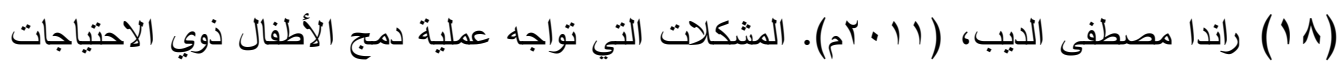
الخاصة، بحث، المؤتمر العلمي الأول، قسم الصحة النفسية، كلية التربية، جامعة بنها. (9 1) زينب شقير ، (999 (م). سيكولوجية الفئات الخاصة والمعوقين، القاهرة: مكتبة النهضة.

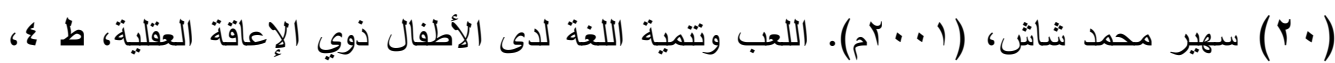
دار القاهرة، القاهرة.

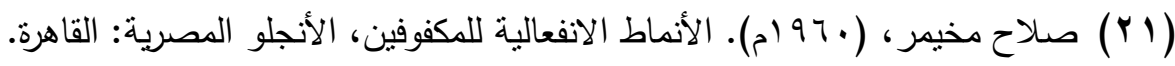

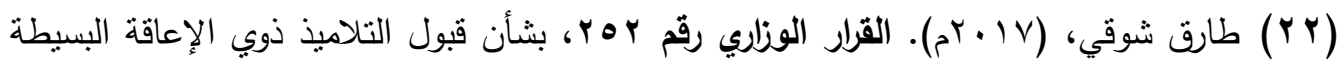

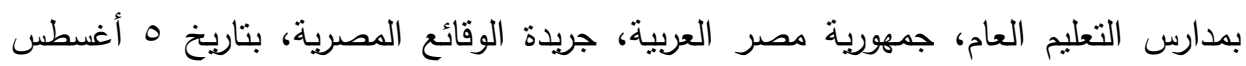
$.0 .1 \mathrm{~T}$

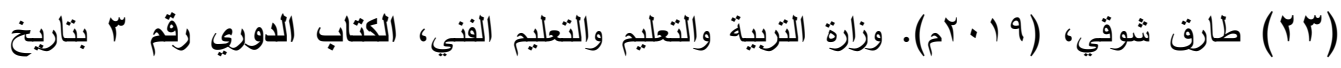
r $19 / 7 / 14$

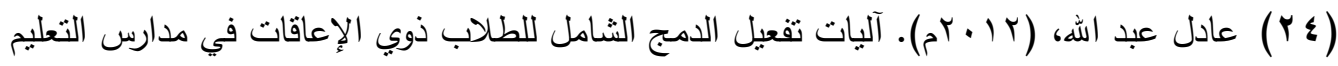

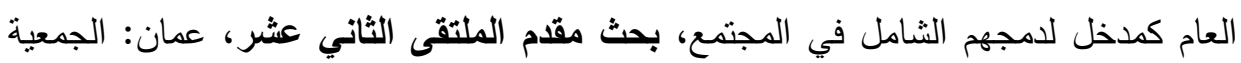

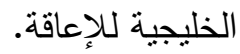


(Y0) عادل كمال خضر، (Y99 (1)). دراسة مقارنة لمفهوم الذات لدى الأطفال الدصابين بالتخلف

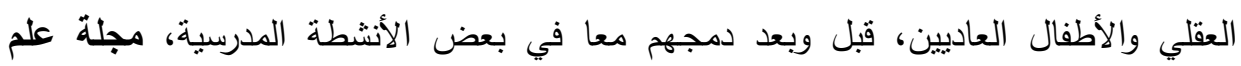

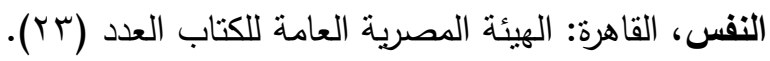

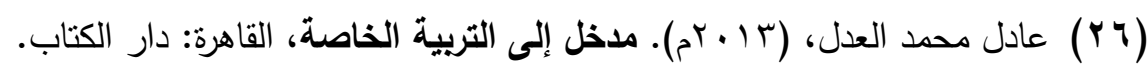
(YV) الصم وبعض المتغيرات المرنبطة به، بحث، ع 9، مجلة كلية التربية، جامعة عين شمس.

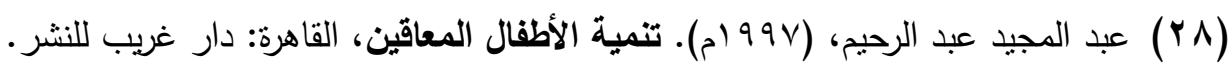

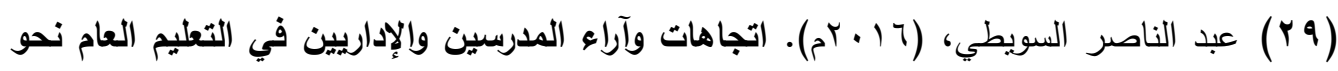
إدماج الأطفال غير العاديين في المدارس الابتدائية العادية في منطقة الخليل، كلية التربية، جامعة الخليل

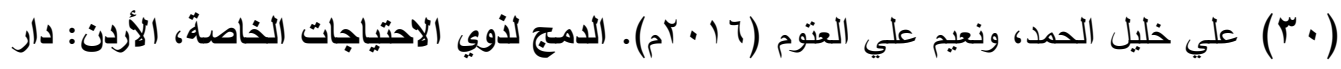
المسيرة. عمر إسماعيل علي، وآخرون، (9 . . rم). الدمج وعلاقته بالثعور بالانتماء لدى الطلاب ذوي

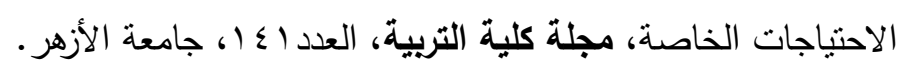

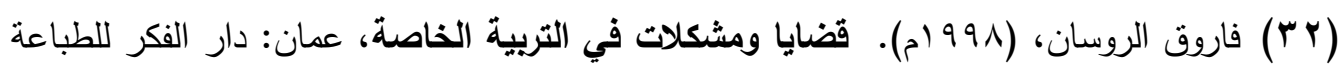
والنشر والتوزيع.

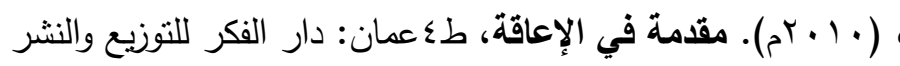

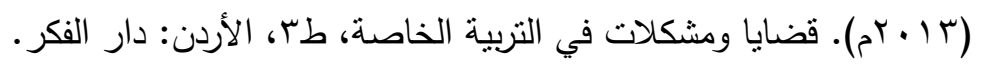

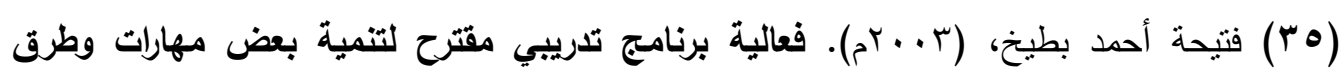

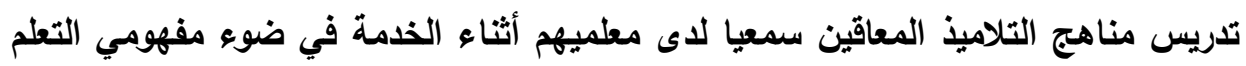

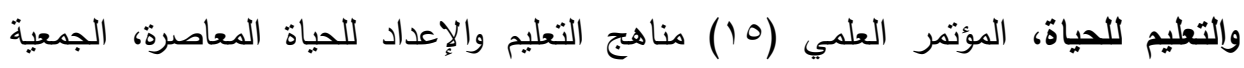
المصرية للمناهج وطرق التدريس.

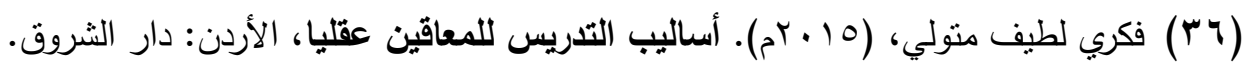

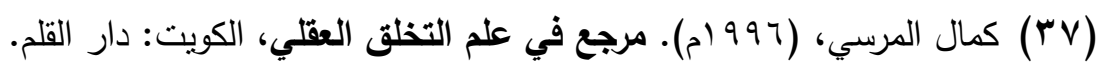

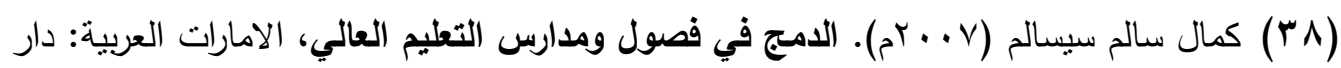
الكتاب الجامعي.

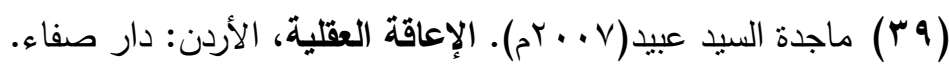




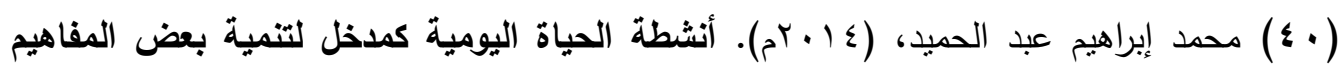

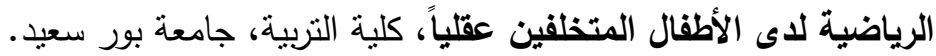

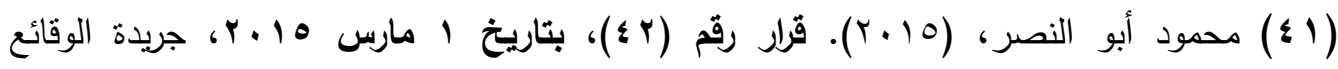

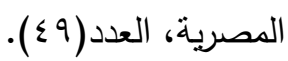

(Y \&) محمود حمودة، (1991(م). الطب النفسي الطفولة والمراهقة (المشكلات النفسية والعلاج)،

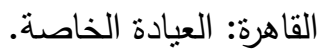

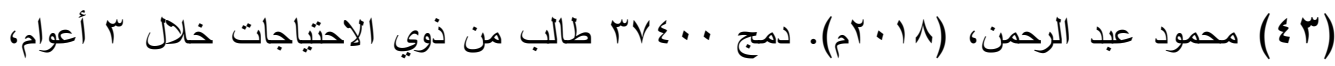

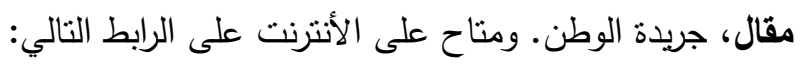
https://www.elwatannews.com/news/details/3786318 (§ §) مدحت أبو النصر، (0. . rم). الإعاقة العقلية المفهوم والأنواع ويرامج الرعاية، القاهرة: مجموعة النيل العربية.

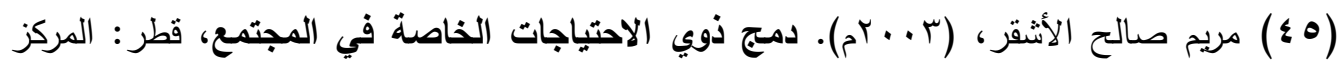

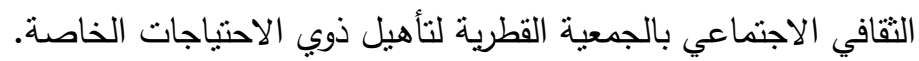

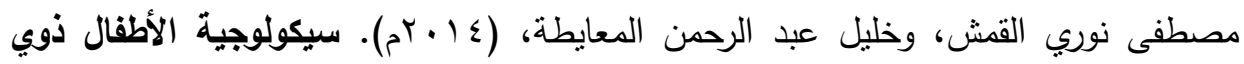
الحاجات الخاصة، الأردن: دار المسيرة.

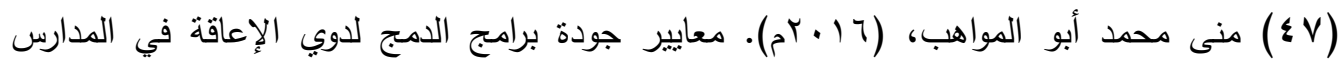

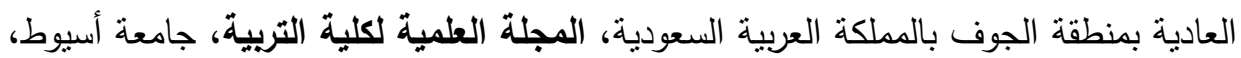

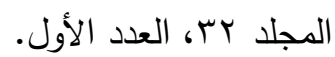

(^§) ياسر محروس مصطفى، (^ +. rم). تقويم تجربة دمج ذوي الاحتياجات الخاصة في النشاط

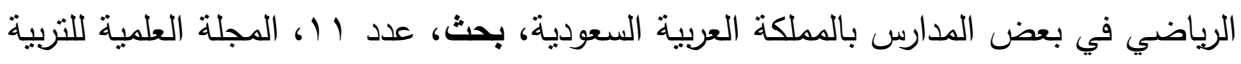
البديلة والرياضية، جامعة حلوان.

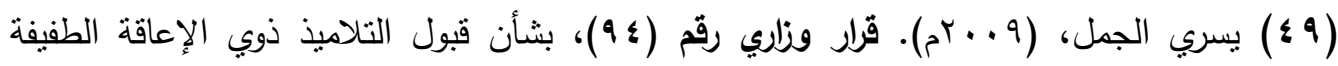

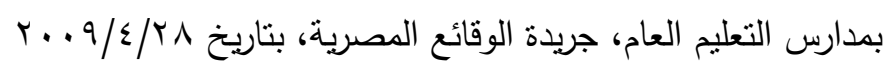

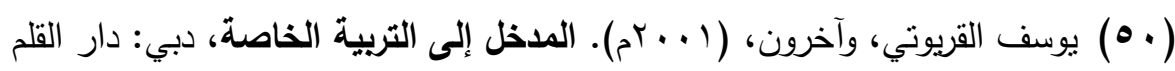
(10) يوسف القيروتي، (1997)م) أساليب تربية الطقل بين النظرية والتطبيق، القاهرة: مكتبة الأنجلو المصرية. 
(52) William, L. (1992). " Exceptional children " An introductory survey of special education, fourth edition, New York, Merrill, an imprint of macmillan publishing company.

(53) Chen, C. (2008). Why Do Teachers Not Practice What They Believe Regarding Technology Integration? Journal of Educational Research, Vol. (102).

(54) Heward, W. (2003). Exceptional Children: An introduction to special education. Upper Sanddle River: Memill \& Prentice Hall. British Journal of Education Vol.5, No.13.

(55) Brigitte, B. (1997). Integration scolaire d'enfants handicapés à l'ecole maternelle: partenariat entre enseignant de l'école ordinaire et professionnels spécialisé. Revue francais de pédagogie.

(56) Platt, M. (2002) Attorneys perceptions of child witnesses with mental retardation, M.S. University of Nevada

(57) Maccanchie H, and Mentally, Y. (2003) Handicapped Children, A Review of Research Issues Brodeline Book. LTD,London

(58) WHO, U. (2015) Assistive Technology for Children with Disabilities: Creating Opportunities for Education, Inclusion and Participation: A discussion paper. Geneva: World Health Organization. www.who.int

(59) Ripley, K., Barrett, J., and others. (2001). Inclusion for Children with Speech and Language Impairments: Accessing the Curriculum and Promoting

(60) Hallahan. D. \& Kauffman, J. (2006). Exceptional children: An introduction to Special Education. Boston: Allyn \& Bacon.

(61) Lemer, J. (2003). Learning disabilities: Theories, diagnosis, and teaching strategies. Boston: Houghton Mifflin Company.

(62) Odom, S. \& Diamond, K. (1998). Inclusion of Young Children with Special needs in early child hood education: The research base. Early Childhood Research Quarterly. V. 13. N. 1.

(63) Wilson, G, (1996). Abnormal Psychology Integration Perspectives. Boston: Allyn \& Bacon Asimon \& Schuster Company. USA.

(64) Kauffman, J. (2013a). Labeling and categorizing children and youth with emotional and behavioral disorders in the USA: Current practices and conceptual problems. In Cole, T., Daniels, H., \& Visser, J. (Eds.), The Routledge international companion to emotional and behavioural difficulties. London: Routledge. 